\title{
ACIDIZING SANDSTONE RESERVOIRS USING HF AND ORGANIC ACIDS
}

\author{
A Thesis \\ by
}

FEI YANG

\begin{abstract}
Submitted to the Office of Graduate Studies of
Texas A\&M University

in partial fulfillment of the requirements for the degree of

MASTER OF SCIENCE
\end{abstract}

August 2012

Major Subject: Petroleum Engineering 
Acidizing Sandstone Reservoirs Using HF and Organic Acids Copyright 2012 Fei Yang 


\title{
ACIDIZING SANDSTONE RESERVOIRS USING HF AND ORGANIC ACIDS
}

\author{
A Thesis \\ by
}

\section{FEI YANG}

\section{Submitted to the Office of Graduate Studies of Texas A\&M University \\ in partial fulfillment of the requirements for the degree of MASTER OF SCIENCE}

Approved by:

Chair of Committee, Hisham A. Nasr-El-Din

Committee Members, Ding Zhu Mahmoud El-Halwagi

Head of Department, Dan Hill

August 2012

Major Subject: Petroleum Engineering 


\begin{abstract}
Acidizing Sandstone Reservoirs Using HF and Organic Acids. (August 2012)

Fei Yang, B.S., Tianjin University

Chair of Advisory Committee: Dr. Hisham A. Nasr-El-Din
\end{abstract}

Mud acid, which is composed of $\mathrm{HCl}$ and $\mathrm{HF}$, is commonly used to remove the formation damage in sandstone reservoirs. However, many problems are associated with $\mathrm{HCl}$, especially at high temperatures.

Formic-HF acids have served as an alternative of mud acid for a long period.

Several factors may influence the outcome of an acidizing job in sandstone formations. In this research, effects of mineralogy, temperature, and HF concentration were studied. Various clay minerals (kaolinite, chlorite, and illite) were examined to react with formic$\mathrm{HF}$ acid mixtures which contain different concentrations of HF. Coreflood experiments on sandstone cores featured by different mineralogy with dimensions of 1.5 in. $\times 6$ in. were also conducted at a flow rate of $5 \mathrm{~cm}^{3} / \mathrm{min}$. Formic or acetic acids were used in preflush stage to remove the carbonates. A series of formic-HF acid mixtures with different ratios and concentrations were tested, and temperature varied from 77 to 350 ${ }^{\circ} \mathrm{F}$. Inductively coupled plasma (ICP), scanning electron microscopy (SEM) and ${ }^{19} \mathrm{~F}$ nuclear magnetic resonance $\left({ }^{19} \mathrm{~F} \mathrm{NMR}\right)$ were employed to follow the reaction kinetics and products. Besides, acetic-HF acid system, which is another important alternative of mud acid, was also investigated to compare with formic-HF acids. 
The species and amounts of reaction products of different clay minerals in organic-HF acids depend on mineral type, acid composition and ratio, and this is further confirmed by coreflood experiments, in which sandstone cores with different mineral compositions give quite different responses to the same acid mixture. As preflush, formic acid becomes more effective in removing carbonate minerals in sandstone cores at higher temperatures. In main flush stage, more concentrated HF can react with more clay minerals, but can also cause higher risk of $\mathrm{CaF}_{2}$ precipitate. Both formic-HF and acetic-HF acids are much milder than mud acid. When reacting with clay minerals, there is no big difference in the behaviors of $13 \mathrm{wt} \%$ acetic-HF acids and $9 \mathrm{wt} \%$ formicHF acids, as long as the HF concentrations are the same. 


\section{DEDICATION}

To my mother 


\section{ACKNOWLEDGEMENTS}

I would like to thank my committee chair, Dr. Nasr-El-Din, and my committee members, Dr. Zhu, and Dr. El-Halwagi, for their guidance and support throughout the course of this research.

Thanks to my colleagues and the department faculty and staff for making my time at Texas A\&M University valuable. Thanks to my friends for their encouragement. I also want to extend my gratitude to Saudi Aramco for funding this research project.

Finally, thanks to my mother and father for their endless love. 


\section{NOMENCLATURE}

AA Acetic Acid

FA Formic Acid

PV Pore Volume 


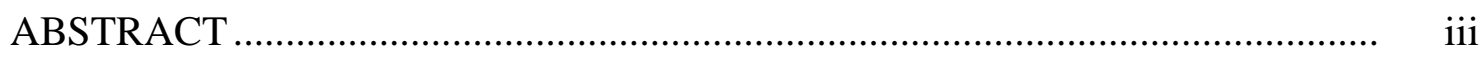

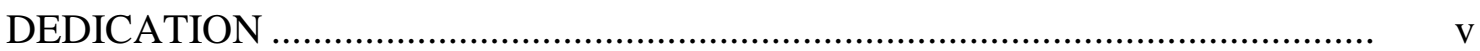

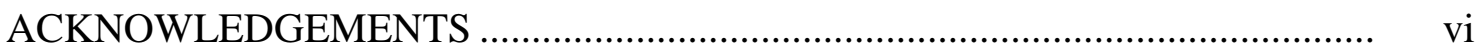

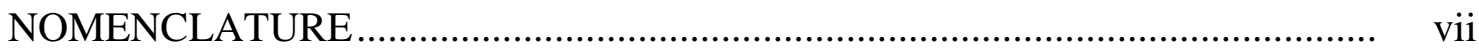

TABLE OF CONTENTS …............................................................................. viii

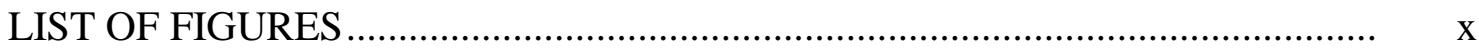

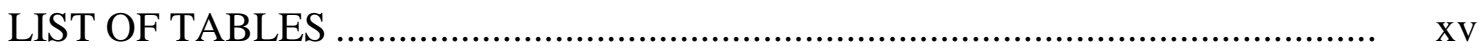

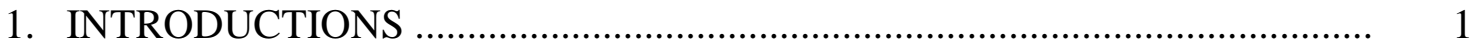

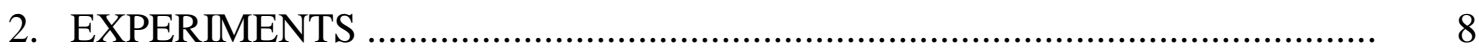

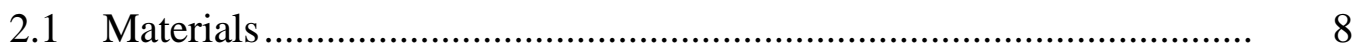

2.2 Formic-HF Acids.............................................................................. 9

2.2.1 Preparation of $9 \mathrm{wt} \%$ formic-HF acids ...................................... 9

2.2.2 Clay solubility test in formic-HF acids ...................................... 11

2.2.3 Core flood experiments on Berea and Bandera sandstone cores using formic-HF acids ............................................................. 13

2.2.4 Core flood experiments on Berea sandstone cores using different amounts of HF ....................................................... 15

2.2.5 Core flood experiments on Berea sandstone cores under different temperatures ............................................................. 16

2.3 Acetic-HF Acids ................................................................................ 18

2.3.1 Preparation of $13 \mathrm{wt} \%$ acetic-HF acids ..................................... 18

2.3.2 Clay solubility test in acetic-HF acids......................................... 19

2.3.3 Core flood experiments on Berea and Bandera sandstone cores using acetic-HF acids ............................................................. 20

3. RESULTS AND DISCUSSIONS ………………................................... 22

$3.1 \quad$ Formic-HF Acids ............................................................................... 22

3.1.1 Clay solubility in formic-HF acids ............................................ 22 
3.1.2 Core flood experiments on Berea and Bandera sandstone cores using formic-HF acids

3.1.3 Core flood experiments on Berea sandstone cores using different amounts of HF

3.1.4 Core flood experiments on Berea sandstone cores under different temperatures

3.2 Acetic-HF Acids

3.2.1 Clay solubility in acetic-HF acids

3.2.2 Core flood experiments on Berea and Bandera sandstone cores using acetic-HF acids

4. CONCLUSIONS 


\section{LIST OF FIGURES}

FIGURE

Page

$1 \quad{ }^{19} \mathrm{~F}$ NMR spectrum of $13.5 \mathrm{wt} \% \mathrm{HCl}-1.5 \mathrm{wt} \% \mathrm{HF}$ reacted with kaolinite at room temperature ........................................................ 4

$2 \quad{ }^{19} \mathrm{~F}$ NMR spectra of aluminum solutions containing varying F/Al rations 5

3 Variable temperature ${ }^{19} \mathrm{~F}$ NMR spectra of $\mathrm{HF}$ acid reacted with $\mathrm{Si}(\mathrm{OH})_{4}$. 6

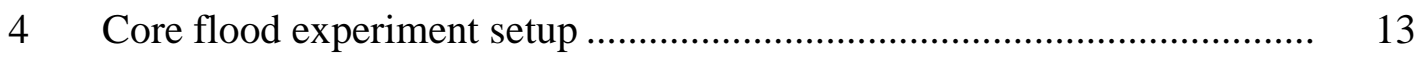

5 Ion concentrations in $9 \mathrm{wt} \%$ formic-HF acid solutions after reactions with kaolinite at room temperature.

$6{ }^{19}$ F NMR spectrum of $9 \mathrm{wt} \%$ formic acid- $0.5 \mathrm{wt} \% \mathrm{HF}$ after reaction with kaolinite for 0.5 hour at $75^{\circ} \mathrm{F}$.

7 Ion concentrations in $9 \mathrm{wt} \%$ formic- $\mathrm{HF}$ acid solutions after reactions with chlorite at room temperature.

8 Ion concentrations in $9 \mathrm{wt} \%$ formic-HF acid solutions after reactions with illite at room temperature.

$9{ }^{19}$ F NMR spectrum of $9 \mathrm{wt} \%$ formic acid- $0.5 \mathrm{wt} \% \mathrm{HF}$ after reaction with chlorite for 0.5 hour at $75^{\circ} \mathrm{F}$.

$10 \quad{ }^{19} \mathrm{~F}$ NMR spectrum of $9 \mathrm{wt} \%$ formic acid- $0.5 \mathrm{wt} \% \mathrm{HF}$ after reaction with illite for 0.5 hour at $75^{\circ} \mathrm{F}$.

11 Pressure drop across the core using $9 \mathrm{wt} \%$ formic acid with $5 \mathrm{wt} \%$ ammonium chloride as a preflush and $3 \mathrm{PV}$ of $9 \mathrm{wt} \%$ formic acid and $1 \mathrm{wt} \% \mathrm{HF}$ as the main flush at $75^{\circ} \mathrm{F}$ and $5 \mathrm{~cm}^{3} / \mathrm{min}$ on a Berea sandstone core

12 Pressure drop across the core using $9 \mathrm{wt} \%$ formic acid with $5 \mathrm{wt} \%$ ammonium chloride as a preflush and $3 \mathrm{PV}$ of $9 \mathrm{wt} \%$ formic acid and $1 \mathrm{wt} \% \mathrm{HF}$ as the main flush at $75^{\circ} \mathrm{F}$ and $5 \mathrm{~cm}^{3} / \mathrm{min}$ on a Bandera sandstone core. 
13 Analysis of coreflood effluent samples for a Berea sandstone core treated by $9 \mathrm{wt} \%$ formic acid with $5 \mathrm{wt} \%$ ammonium chloride as a preflush and $3 \mathrm{PV}$ of $9 \mathrm{wt} \%$ formic acid with $1 \mathrm{wt} \% \mathrm{HF}$ as the main flush at $75^{\circ} \mathrm{F}$ and $5 \mathrm{~cm}^{3} / \mathrm{min}$.

14 Analysis of coreflood effluent samples for a Bandera sandstone core treated by $9 \mathrm{wt} \%$ formic acid with $5 \mathrm{wt} \%$ ammonium chloride as a preflush and $3 \mathrm{PV}$ of $9 \mathrm{wt} \%$ formic- $1 \mathrm{wt} \% \mathrm{HF}$ as the main flush at $75^{\circ} \mathrm{F}$ and $5 \mathrm{~cm}^{3} / \mathrm{min}$

15 Analysis of coreflood effluent samples for a Berea sandstone core treated by $9 \mathrm{wt} \%$ formic acid with $5 \mathrm{wt} \%$ ammonium chloride as a preflush and $3 \mathrm{PV}$ of $9 \mathrm{wt} \%$ formic acid with $1 \mathrm{wt} \% \mathrm{HF}$ as the main flush at $75^{\circ} \mathrm{F}$ and $5 \mathrm{~cm}^{3} / \mathrm{min}$.

16 Pressure drop across the core using $9 \mathrm{wt} \%$ formic acid with $5 \mathrm{wt} \%$ ammonium chloride as a preflush and $3 \mathrm{PV}$ of $9 \mathrm{wt} \%$ formic acid and $1 \mathrm{wt} \% \mathrm{HF}$ as the main flush at $75^{\circ} \mathrm{F}$ and $5 \mathrm{~cm}^{3} / \mathrm{min}$ on a Berea sandstone core.

17 Analysis of coreflood effluent samples for a Berea sandstone core treated by $9 \mathrm{wt} \%$ formic acid with $5 \mathrm{wt} \%$ ammonium chloride as a preflush and $3 \mathrm{PV}$ of $9 \mathrm{wt} \%$ formic acid with $2 \mathrm{wt} \% \mathrm{HF}$ as the main flush at $75^{\circ} \mathrm{F}$ and $5 \mathrm{~cm}^{3} / \mathrm{min}$

18 Pressure drop across the core using $9 \mathrm{wt} \%$ formic acid with $5 \mathrm{wt} \%$ ammonium chloride as a preflush and $3 \mathrm{PV}$ of $9 \mathrm{wt} \%$ formic acid and $2 \mathrm{wt} \% \mathrm{HF}$ as the main flush at $75^{\circ} \mathrm{F}$ and $5 \mathrm{~cm}^{3} / \mathrm{min}$ on a Berea sandstone core.

19 CT number across the Berea sandstone core before and after the acid treatment using $9 \mathrm{wt} \%$ formic acid with $5 \mathrm{wt} \%$ ammonium chloride as a preflush and $3 \mathrm{PV}$ of $9 \mathrm{wt} \%$ formic acid with $1 \mathrm{wt} \%$ $\mathrm{HF}$ as the main flush at $75^{\circ} \mathrm{F}$ and $5 \mathrm{~cm}^{3} / \mathrm{min}$.

20 CT number across the Berea sandstone core before and after the acid treatment using $9 \mathrm{wt} \%$ formic acid with $5 \mathrm{wt} \%$ ammonium chloride as a preflush and $3 \mathrm{PV}$ of $9 \mathrm{wt} \%$ formic acid with $2 \mathrm{wt} \%$ $\mathrm{HF}$ as the main flush at $75^{\circ} \mathrm{F}$ and $5 \mathrm{~cm}^{3} / \mathrm{min}$. 
21 Pressure drop across the core using $9 \mathrm{wt} \%$ formic acid with $5 \mathrm{wt} \%$ ammonium chloride as a preflush and $1 \mathrm{PV}$ of $9 \mathrm{wt} \%$ formic acid and $0.5 \mathrm{wt} \% \mathrm{HF}$ as the main flush at $75^{\circ} \mathrm{F}$ and $5 \mathrm{~cm}^{3} / \mathrm{min}$ on a Berea sandstone core

22 Analysis of coreflood effluent samples for a Berea sandstone core treated by $9 \mathrm{wt} \%$ formic acid with $5 \mathrm{wt} \%$ ammonium chloride as a preflush and $1 \mathrm{PV}$ of $9 \mathrm{wt} \%$ formic acid with $0.5 \mathrm{wt} \% \mathrm{HF}$ as the main flush at room temperature and $5 \mathrm{~cm}^{3} / \mathrm{min}$.

23 Pressure drop across the core using $9 \mathrm{wt} \%$ formic acid at $75^{\circ} \mathrm{F}$ and $5 \mathrm{~cm}^{3} / \mathrm{min}$ on a Berea sandstone core

24 Analysis of coreflood effluent samples of a Berea sandstone core treated by $9 \mathrm{wt} \%$ formic acid at $75^{\circ} \mathrm{F}$ and $5 \mathrm{~cm}^{3} / \mathrm{min}$

25 Pressure drop across the core using $9 \mathrm{wt} \%$ formic acid at $250^{\circ} \mathrm{F}$ and $5 \mathrm{~cm}^{3} / \mathrm{min}$ on a Berea sandstone core.

26 Analysis of coreflood effluent samples of a Berea sandstone core treated by $9 \mathrm{wt} \%$ formic acid at $250^{\circ} \mathrm{F}$ and $5 \mathrm{~cm}^{3} / \mathrm{min}$.

27 Pressure drop across the core using $9 \mathrm{wt} \%$ formic acid with $5 \mathrm{wt} \%$ ammonium chloride as a preflush and $1 \mathrm{PV}$ of $9 \mathrm{wt} \%$ formic acid and $0.5 \mathrm{wt} \% \mathrm{HF}$ as the main flush at $150^{\circ} \mathrm{F}$ and $5 \mathrm{~cm}^{3} / \mathrm{min}$ on a Berea sandstone core

28 Pressure drop across the core using $9 \mathrm{wt} \%$ formic acid with $5 \mathrm{wt} \%$ ammonium chloride as a preflush and $1 \mathrm{PV}$ of $9 \mathrm{wt} \%$ formic acid and $0.5 \mathrm{wt} \% \mathrm{HF}$ as the main flush at $250^{\circ} \mathrm{F}$ and $5 \mathrm{~cm}^{3} / \mathrm{min}$ on a Berea sandstone core

29 Pressure drop across the core using $9 \mathrm{wt} \%$ formic acid with $5 \mathrm{wt} \%$ ammonium chloride as a preflush and $1 \mathrm{PV}$ of $9 \mathrm{wt} \%$ formic acid and $0.5 \mathrm{wt} \% \mathrm{HF}$ as the main flush at $350^{\circ} \mathrm{F}$ and $5 \mathrm{~cm}^{3} / \mathrm{min}$ on a Berea sandstone core

30 CT number across the Berea sandstone core before and after the acid treatment using $9 \mathrm{wt} \%$ formic acid with $5 \mathrm{wt} \%$ ammonium chloride as a preflush and $1 \mathrm{PV}$ of $9 \mathrm{wt} \%$ formic acid with $0.5 \mathrm{wt} \% \mathrm{HF}$ as the main flush at $150^{\circ} \mathrm{F}$ and $5 \mathrm{~cm}^{3} / \mathrm{min}$.... 
31 Analysis of coreflood effluent samples for a Berea sandstone core treated by $9 \mathrm{wt} \%$ formic acid with $5 \mathrm{wt} \%$ ammonium chloride as a preflush and $1 \mathrm{PV}$ of $9 \mathrm{wt} \%$ formic acid with $0.5 \mathrm{wt} \% \mathrm{HF}$ as the main flush at $150^{\circ} \mathrm{F}$ and $5 \mathrm{~cm}^{3} / \mathrm{min}$.

32 Analysis of coreflood effluent samples for a Berea sandstone core treated by $9 \mathrm{wt} \%$ formic acid with $5 \mathrm{wt} \%$ ammonium chloride as a preflush and $1 \mathrm{PV}$ of $9 \mathrm{wt} \%$ formic acid with $0.5 \mathrm{wt} \% \mathrm{HF}$ as the main flush at $250^{\circ} \mathrm{F}$ and $5 \mathrm{~cm}^{3} / \mathrm{min}$.

33 Analysis of coreflood effluent samples for a Berea sandstone core treated by $9 \mathrm{wt} \%$ formic acid with $5 \mathrm{wt} \%$ ammonium chloride as a preflush and $1 \mathrm{PV}$ of $9 \mathrm{wt} \%$ formic acid with $0.5 \mathrm{wt} \% \mathrm{HF}$ as the main flush at $350^{\circ} \mathrm{F}$ and $5 \mathrm{~cm}^{3} / \mathrm{min}$

34 Ion concentrations in $13 \mathrm{wt} \%$ acetic-HF acid solutions after reactions with kaolinite at room temperature

35 Ion concentrations in $13 \mathrm{wt} \%$ acetic-HF acid solutions after reactions with chlorite at room temperature

36 Ion concentrations in $13 \mathrm{wt} \%$ acetic-HF acid solutions after reactions with illite at room temperature

$37{ }^{19}$ F NMR spectrum of $13 \mathrm{wt} \%$ acetic acid- $0.5 \mathrm{wt} \%$ HF after reaction with kaolinite for 0.5 hour at $75^{\circ} \mathrm{F}$...

$38{ }^{19} \mathrm{~F}$ NMR spectrum of $13 \mathrm{wt} \%$ acetic acid- $0.5 \mathrm{wt} \%$ HF after reaction with chlorite for 0.5 hour at $75^{\circ} \mathrm{F}$.

$39{ }^{19} \mathrm{~F}$ NMR spectrum of $13 \mathrm{wt} \%$ acetic acid- $0.5 \mathrm{wt} \%$ HF after reaction with illite for 0.5 hour at $75^{\circ} \mathrm{F}$.

40 Element analysis of kaolinite after treated with $13 \mathrm{wt} \%$ acetic acid$6 \mathrm{wt} \% \mathrm{HF}$ at room temperature

41 Element analysis of chlorite after treated with $13 \mathrm{wt} \%$ acetic acid$6 \mathrm{wt} \% \mathrm{HF}$ at room temperature

42 Element analysis of illite after treated with $13 \mathrm{wt} \%$ acetic acid-6 wt $\%$ $\mathrm{HF}$ at room temperature 
43 Analysis of core flood effluent samples for a Berea sandstone core treated by $13 \mathrm{wt} \%$ acetic acid with $5 \mathrm{wt} \%$ ammonium chloride as a preflush and $3 \mathrm{PV}$ of $13 \mathrm{wt} \%$ acetic acid with $1 \mathrm{wt} \% \mathrm{HF}$ as the main flush at $75^{\circ} \mathrm{F}$ and $5 \mathrm{~cm}^{3} / \mathrm{min}$

44 Analysis of core flood effluent samples for a Bandera sandstone core treated by $13 \mathrm{wt} \%$ acetic acid with $5 \mathrm{wt} \%$ ammonium chloride as a preflush and $3 \mathrm{PV}$ of $13 \mathrm{wt} \%$ acetic acid with 1 wt $\% \mathrm{HF}$ as the main flush at $75^{\circ} \mathrm{F}$ and $5 \mathrm{~cm}^{3} / \mathrm{min}$ 


\section{LIST OF TABLES}

TABLE $\quad$ Page

1 Weight percentage of elements in clay minerals ................................... 8

2 Mineral composition of Berea and Bandera sandstone cores based on weight ...................................................................... 9

3 Acid composition and clay type for clay solubility test in formicHF acids

4 Experimental conditions of core flood experiments on Berea and Bandera sandstone cores using formic-HF acids

5 Experimental conditions of core flood experiments on Berea sandstone cores using different amounts of formic-HF acids.

6 Experimental conditions of core flood experiments on Berea sandstone cores under different temperatures using formic acid

7 Experimental conditions of core flood experiments on Berea sandstone cores under different temperatures using formic-HF acids.

8 Acid composition and clay type for clay solubility test in aceticHF acids

9 Experimental conditions of core flood experiment using aceticHF acids. 


\section{INTRODUCTIONS}

The goal of acidizing sandstone reservoirs is to remove the formation damage caused by drilling, work over, or completion processes, thus to restore the original permeability of the formation. Three main steps are involved, including preflush, main flush, and post flush. In the main stage, mixtures of $\mathrm{HF}$ and $\mathrm{HCl}$ have been extensively employed in the field (Smith and Hendrickson 1965; Gidley 1985). The role of hydrofluoric acid (HF) is to dissolve aluminosilicates and silica, while hydrochloric acid lowers $\mathrm{pH}$, thus keeps reaction products soluble in spent acids.

Field reports showed variable success rates of the treatments using mud acid and formation damage was even reported in some cases (Simon and Anderson 1990). These unsatisfying results were attributed to many drawbacks of this conventional system. First, in the zones that are not adequately covered by preflush, there is a high risk of secondary and tertiary reactions. Second, HCl-senstive clays (e.g., illite) can cause formation damage and decrease the permeability. Third, the high reaction and corrosion rates also cause many problems (Simon and Anderson 1990; Gdanski and Shuchart 1996; Thomas et al. 2002). These problems can be worse at high bottomhole temperatures, due to the accelerated reaction rate and higher corrosivity of the acid system.

To overcome the problems associated with mud acid, organic-HF acids have been used as an alternative to mud acid (Abrams et al. 1983; Shuchart and Gdanski. 1996; Taylor et al. 2005; Al-Harbi et al. 2011).

This thesis follows the style of SPE Production and Operations. 
Among them, formic and acetic acids are the most commonly used ones to substitute for $\mathrm{HCl}$. In our research, stimulation of sandstone reservoirs employing formic-HF acids or acetic-HF acids is investigated.

Both formic and acetic acids are weak acids, and the dissociation equations and the dissociation constants are given in Eq. 1 and 2 (Perrin 1981). Acetic and formic acids were normally used at concentrations of $13 \mathrm{wt} \%$ and $9 \mathrm{wt} \%$ or less, otherwise some reaction products may precipitate (Blake and Walter, 1999).

$$
\begin{gathered}
\mathrm{HCOOH} \leftrightarrow \mathrm{H}^{+}+\mathrm{HCOO}^{-}\left(\mathrm{pK}_{\mathrm{a}, \mathrm{FA}}=3.75\right) \\
\mathrm{CH}_{3} \mathrm{COOH} \leftrightarrow \mathrm{H}^{+}+\mathrm{HCOO}^{-}\left(\mathrm{pK}_{\mathrm{a}, \mathrm{AA}}=4.76\right)
\end{gathered}
$$

The main purpose of preflush is to remove carbonates. The reaction between organic acid and calcite at high pressure is given in Eq. 1 (Chatelain et al. 1976).

$$
2 \mathrm{H}^{+}(\mathrm{aq})+\mathrm{CaCO}_{3} \leftrightarrow \mathrm{Ca}^{2+}(\mathrm{aq})+\mathrm{H}_{2} \mathrm{O}+\mathrm{CO}_{2}
$$

When weak acid reacts on the surface of calcite, the consumption of $\mathrm{H}^{+}$can drive the acid dissociation to the right of Eq. 3. Undissociated acids are transported to the surface by diffusion, and then the $\mathrm{H}^{+}$ions are generated in situ through dissociation (Eqs. 1 and 2). When $\mathrm{pH}$ is less than 4, the backward reaction can be ignored, and the forward reaction rate depends on both $\mathrm{H}^{+}$concentration, and the reaction rate constant (k) (Buijse et al. 2004).

Though research has been done regarding the organic-acid/carbonates system (Chatelain et al. 1976; Buijse et al. 2004; Chang et al 2008), none of it was targeted at the carbonates in sandstone reservoirs. One paper reported that when $14 \mathrm{wt} \%$ formic acid was used as preflush on a Muzza sandstone core at $400^{\circ} \mathrm{F}$, calcium concentration 
started to decrease after 8 PV (Scheuerman 1988). Nowadays, it is known that formic acid is often used at a concentration of $9 \mathrm{wt} \%$ in the field, because calcium formate can precipitate at higher concentrations (Blake and Walter 1999). But there is no study to show the effectiveness of $9 \mathrm{wt} \%$ formic acid in removing carbonates in sandstone reservoirs at various temperatures.

In sandstone acidizing, HF acid dissolves aluminosilicates, and organic acids help to maintain a low $\mathrm{pH}$, which is necessary to keep reaction products soluble. HF is a weak acid. Its dissociation equation and dissociation constant at room temperature are given in Eq. 4 (Perrin 1981).

$$
\mathrm{HF} \leftrightarrow \mathrm{H}^{+}+\mathrm{F}^{-}\left(\mathrm{pK}_{\mathrm{a}, \mathrm{HF}}=3.17\right)
$$

Though acetic-HF and formic-HF acids have been applied for a long period, not much work has been done to understand these systems (Shuchart and Gdanski 1996). The chemistry involved in organic-HF acidizing is complicated, due to the complexity of reaction products, mineralogy, reaction mechanism, and so on. A lot of modern analytical techniques have been employed, to interpret the chemical reactions involved, including inductively coupled plasma (ICP), atomic absorption spectroscopies (AA), scanning electron microscopy (SEM), X-ray diffraction (XRD), and X-ray fluorescence (XRF), etc. ${ }^{19} \mathrm{~F}$ nuclear magnetic resonance spectrometry $\left({ }^{19} \mathrm{~F}\right.$ NMR) was first employed by Schuchart and Buster (1995) to investigate the reactions between clays and $\mathrm{HCl}-\mathrm{HF}$ acids. This technique can detect the chemical species containing fluoride in their structure. 
Schuchart and Buster (1995) first analyzed a sample of $13.5 \mathrm{wt} \% \mathrm{HCl}-1.5 \mathrm{wt} \%$ $\mathrm{HF}$ after reaction with kaolinite. They found two groups of signals in the ${ }^{19} \mathrm{~F} \mathrm{NMR}$ spectrum at around $-50 \mathrm{ppm}$ and $-80 \mathrm{ppm}$ respectively when using $\mathrm{CF}_{3} \mathrm{COOH}$ as reference (Fig. 1). The signals around $-80 \mathrm{ppm}$ were assigned to belong to aluminum fluorides, while the ones around $-50 \mathrm{ppm}$ belong to silicon fluorides. They further did more research to understand the reactions between aluminosilicate and $\mathrm{HF}$ using ${ }^{19} \mathrm{~F}$ NMR.

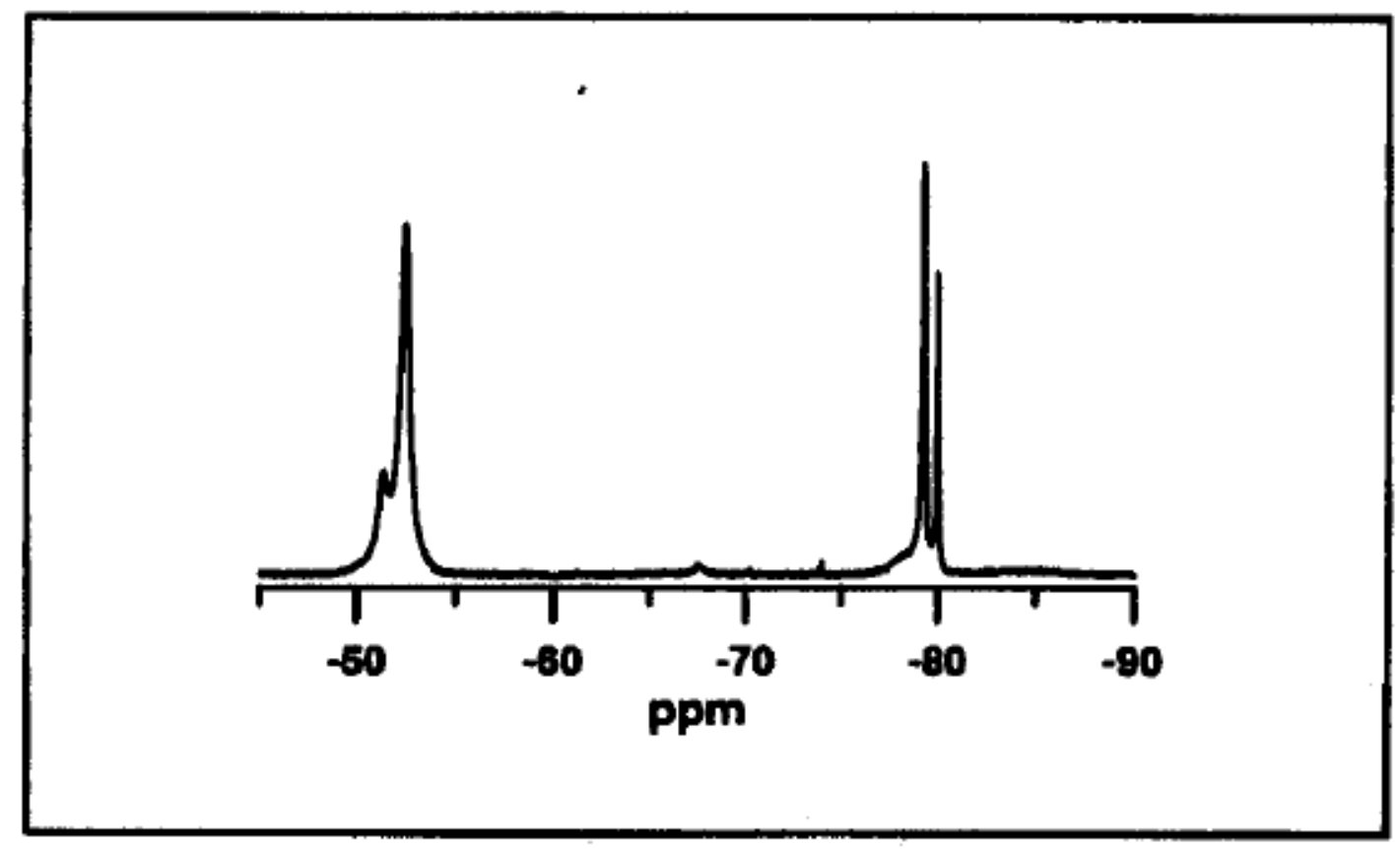

Fig. 1- ${ }^{19} \mathrm{~F}$ NMR spectrum of $13.5 \mathrm{wt} \% \mathrm{HCl}-1.5 \mathrm{wt} \% \mathrm{HF}$ reacted with kaolinite at room temperature (Shuchart and Gdanski 1996).

Theoretically, aluminum can coordinate with up to 6 fluoride ions to complete the octahedral coordination. Therefore, aluminum and fluoride can form several 
different complexes including $\mathrm{AlF}^{2+}, \mathrm{AlF}_{2}{ }^{+}, \mathrm{AlF}_{3}, \mathrm{AlF}_{4}^{-}, \mathrm{AlF}_{5}{ }^{2-}$, and $\mathrm{AlF}_{6}{ }^{3-}$. However, the distribution of different aluminum fluoride complexes depends on a lot of factors, such as the concentrations of ions, ionic strength, and $\mathrm{pH}$, etc. Schuchart and Buster (1995) found that under acetic condition, when vary F/Al ratio from 0.2 to 6.26 , only significant amount of $\mathrm{AlF}_{2}{ }^{+}$and $\mathrm{AlF}^{2+}$ were detected by ${ }^{19} \mathrm{~F} \mathrm{NMR} . \mathrm{AlF}^{2+}$ signal was observed more upfield (lower ppm) than $\mathrm{AlF}_{2}^{+}$(Fig. 2). Since F/Al ratio was increased to 2.27 , HF started to form in solution, and gave a signal at $-85.5 \mathrm{ppm}$.

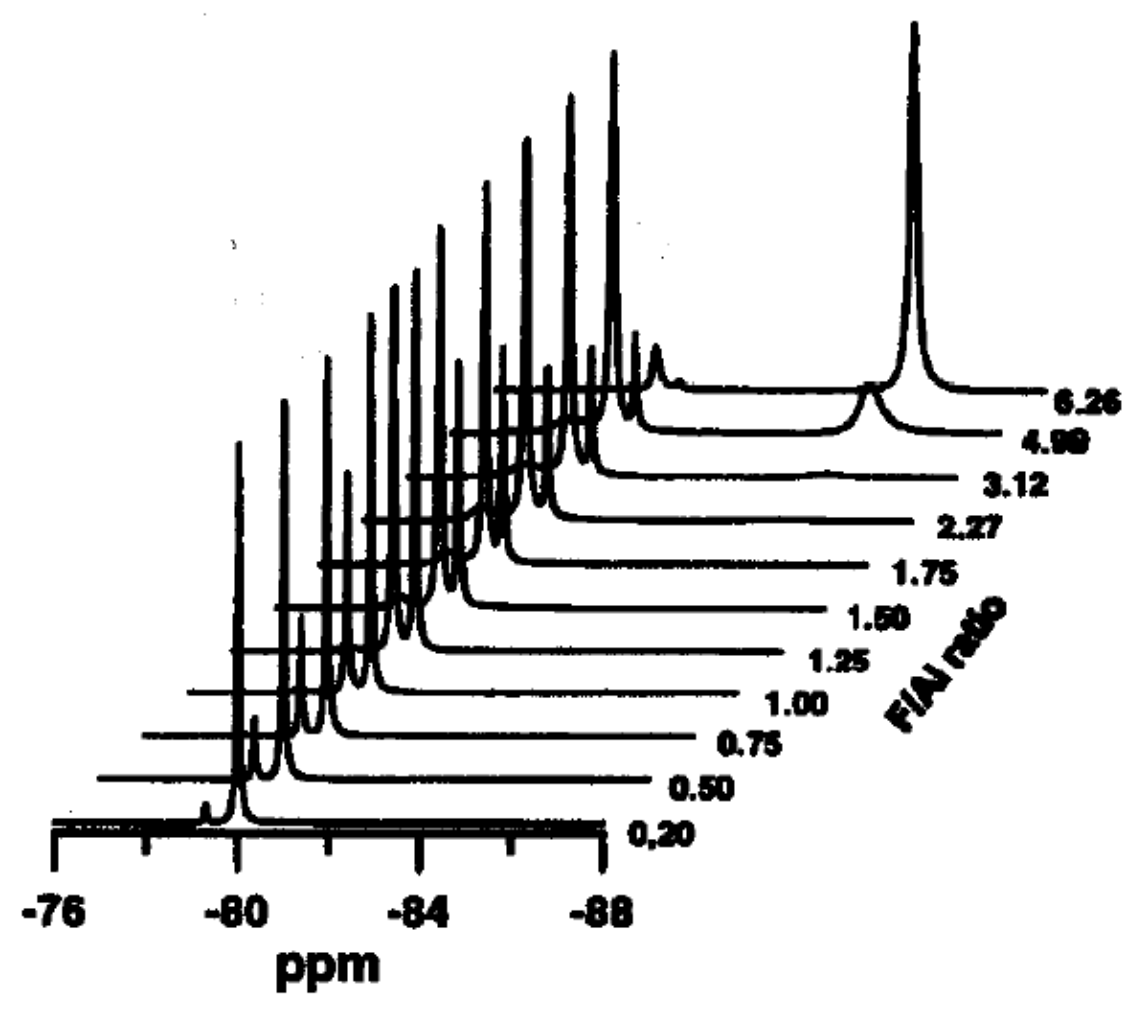

Fig. 2- ${ }^{19} \mathrm{~F}$ NMR spectra of aluminum solutions containing varying $\mathrm{F} / \mathrm{Al}$ rations (Shuchart and Gdanski 1996). 
Researches used to believe that after the reaction of aluminosilicate with HF, silicon was dissolved in the form of $\mathrm{H}_{2} \mathrm{SiF}_{6}$. However, it was later found by ${ }^{19} \mathrm{~F} \mathrm{NMR}$ that after reaction between $15 \mathrm{wt} \% \mathrm{HCl}-3 \mathrm{wt} \% \mathrm{HF}$ and $\mathrm{Si}(\mathrm{OH})_{4}$, one single was peak was observed on ${ }^{19}$ F NMR spectrum at first. However, more peaks started to appear when lower the temperature (Fig. 3). And a total of five peaks were observed at $-45^{\circ} \mathrm{C}$, which were assigned as $\mathrm{SiF}_{3}\left(\mathrm{H}_{2} \mathrm{O}\right)_{3}{ }^{+}$, equatorial fluoride of $\mathrm{SiF}_{5}\left(\mathrm{H}_{2} \mathrm{O}\right)^{-}, \mathrm{SiF}_{6}{ }^{2-}$, $\mathrm{SiF}_{4}\left(\mathrm{H}_{2} \mathrm{O}\right)_{2}$, and axial fluoride of $\mathrm{SiF}_{5}\left(\mathrm{H}_{2} \mathrm{O}\right)^{-}$, respectively. The broad peak observed on ${ }^{19}$ F NMR spectrum under room temperature was caused by fast exchange of different silicon fluoride species.

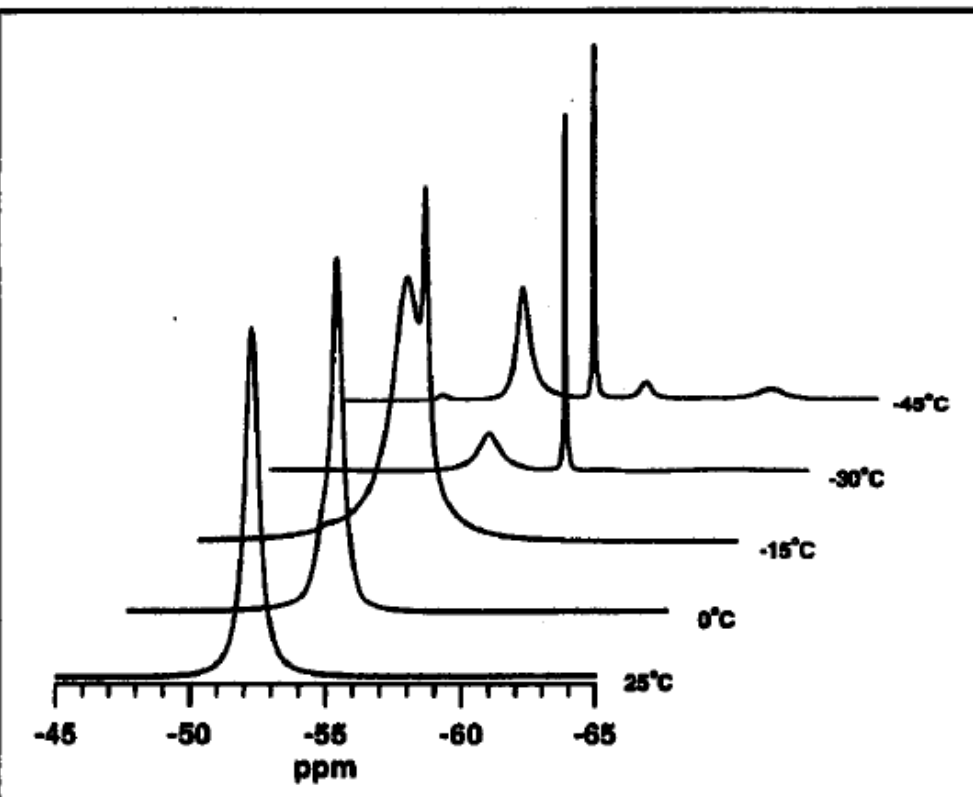

Fig. 3 - Variable temperature ${ }^{19} \mathrm{~F}$ NMR spectra of $\mathrm{HF}$ acid reacted with $\mathrm{Si}(\mathrm{OH})_{4}($ Shuchart and Gdanski1996). 
It was found that there were actually three orders of reactions involved between $\mathrm{HF}$ and clays. The reaction kinetics of primary, secondary, and tertiary reactions have all been reported (Gdanski 1998, 1999, 2000), and are briefly described below.

Primary reaction between HF and aluminosilicates can be generally written in form of Eq. 5 (Gdanski 2000).

$$
(5+x) \mathrm{HF}+\mathrm{M}-\mathrm{Al}-\mathrm{Si}+(3-\mathrm{x}+1) \mathrm{H}^{+} \rightarrow \mathrm{HSiF}_{5}+\mathrm{AlF}_{\mathrm{x}}^{(3-\mathrm{x})}+\mathrm{M}^{+}+\mathrm{H}_{2} \mathrm{O}
$$

Where: $\mathrm{x}=$ number of fluoride ions required to dissolve each $\mathrm{Al} ; \mathrm{M}=$ other cations, such as $\mathrm{Na}^{+}$.

Kinetics of this reaction is dominated by mass-transfer effect and is faster at higher temperatures (Gdanski 2000).

The secondary reaction is the one between fluosilicic acid and aluminosilicates (Eq. 6) (Gdanski 1999).

$$
\mathrm{x} / 5 \mathrm{HSiF}_{5}+\mathrm{M}-\mathrm{Al}-\mathrm{Si}+(3-\mathrm{x}+1) \mathrm{H}^{+}+\mathrm{H}_{2} \mathrm{O} \rightarrow \mathrm{AlF}_{\mathrm{x}}{ }^{(3-\mathrm{x})}+\mathrm{M}^{+}+\text {silica gel } \ldots \ldots .
$$

The rate constant of secondary reaction was found to be very sensitive to temperature. Below $125^{\circ} \mathrm{F}$, this reaction was very slow, but the speed above $125^{\circ} \mathrm{F}$ was very fast and quickly went to completion (Gdanski 1999).

The tertiary reaction was reported in general form of Eq. 7 (Shuchart and Buster 1995).

$\mathrm{y} \mathrm{AlF}_{\mathrm{x}}{ }^{3-\mathrm{x}}+(\mathrm{x}-\mathrm{y}) \mathrm{Al}-\mathrm{Si}+3(\mathrm{x}-\mathrm{y}) \mathrm{H}^{+} \rightarrow \mathrm{x} \mathrm{AlF}_{\mathrm{y}}{ }^{3-\mathrm{y}}+(\mathrm{x}-\mathrm{y})$ silica gel

Where: $\mathrm{y}=$ number of fluorides coordinated with Al after tertiary reaction.

The rate constant of tertiary reaction was determined under various temperatures and the reaction with clay was found to be very slow below $200^{\circ} \mathrm{F}$ (Gdanski 1998). 


\section{EXPERIMENTS}

\subsection{Materials}

Formic, acetic, and hydrochloric acids were obtained from Sigma-Aldrich with concentrations of 99.0, 96.0, and $36.5 \mathrm{wt} \%$, respectively. Ammonium chloride was obtained from Sigma with an assay of more than $99.5 \mathrm{wt} \%$. Ammonium bifluoride was supplied by Alfa Aesar, and the purity was $95 \mathrm{wt} \%$.

All clay minerals (kaolinite, chlorite and illite) were obtained from Ward's company in bulk form. They were grinded and sifted. The diameters of clay particles used in all the experiments are within the range of 50 and $100 \mu \mathrm{m}$. The element composition of these three clay minerals is shown in Table $\mathbf{1 .}$

Table 1 Weight percentage of elements in clay minerals

\begin{tabular}{|c|c|c|c|}
\hline Element, wt\% & Kaolinite & Chlorite & Illite \\
\hline $\mathrm{Si}$ & 19.72 & 11.85 & 23.52 \\
\hline $\mathrm{Al}$ & 19.33 & 12.92 & 11.06 \\
\hline $\mathrm{Fe}$ & 0 & 9.22 & 3.09 \\
\hline $\mathrm{Mg}$ & 0 & 13.45 & 2.19 \\
\hline
\end{tabular}

Both Berea and Bandera sandstone cores were used in the experiments. Core plugs were cut from Berea or Bandera sandstone blocks and the size of the cores was 1.5 
in. $\times 6$ in. The mineralogy of the Berea and Bandera sandstone cores are given in Table

2.

Table 2 Mineral Composition of Berea and Bandera sandstone cores based on weight

\begin{tabular}{|c|c|c|}
\hline Mineral, wt\% & Berea & Bandera \\
\hline Quartz & 86 & 16 \\
\hline Dolomite & 1 & - \\
\hline Calcite & 2 & 12 \\
\hline Feldspar & 3 & 3 \\
\hline Kaolinite & 5 & 10 \\
\hline Illite & 1 & 1 \\
\hline Chlorite & 2 & \\
\hline
\end{tabular}

\subsection{Formic-HF Acids}

\subsubsection{Preparation of 9 wt\% formic- $\mathrm{HF}$ acids}

9 wt \% Formic acid solutions with different concentrations of HF acid were

prepared. All HF used in this experiment is produced by mixing ammonium bifluoride $\left(\mathrm{NH}_{4} \cdot \mathrm{HF}_{2}\right)$ and $\mathrm{HCl}(\mathrm{Eq} .8)$.

$\mathrm{NH}_{4} \cdot \mathrm{HF}_{2}+\mathrm{HCl} \rightarrow 2 \mathrm{HF}+2 \mathrm{NH}_{4} \mathrm{Cl}$ 
So to prepare this acid mixture, formic acid, hydrochloric acid, water, and ammonium bifluoride were needed. Take the preparation of $200 \mathrm{~g}$ of $9 \mathrm{wt} \%$ formic-1 wt $\%$ HF acids as an example.

- Necessary information

Water: Density is $1 \mathrm{~g} / \mathrm{ml}$

Ammonium bifluoride: Molecular Weight (MW) is $57 \mathrm{~g} / \mathrm{mol}$

Purity is $95 \mathrm{wt} \%$

Formic acid: Purity is $96 \mathrm{wt} \%$

Density is $1.2 \mathrm{~g} / \mathrm{ml}$

Hydrochloric acid: Purity is $36.5 \mathrm{wt} \%$

Density is $1.18 \mathrm{~g} / \mathrm{ml}$

- Volume of $96 \%$ formic acid needed

$200 \mathrm{~g} \times 9 \mathrm{wt} \%=18 \mathrm{~g}$ of pure formic acid

$18 \mathrm{~g} / 96 \mathrm{wt} \%=18.75 \mathrm{~g}$ of $96 \%$ formic acid

$18.75 \mathrm{~g} /(1.2 \mathrm{~g} / \mathrm{ml})=15.625 \mathrm{ml}$ of $96 \%$ formic acid

- Molar mass of HF

$200 \mathrm{~g} \times 1 \mathrm{wt} \%=2 \mathrm{~g} \mathrm{HF}$

$2 \mathrm{~g} /(20 \mathrm{~g} / \mathrm{mol})=0.1 \mathrm{~mol}$

Based on Eq.8, $0.05 \mathrm{~mol}$ of $\mathrm{HCl}$ and $0.05 \mathrm{~mol}$ of ammonium bifluoride are needed.

- Volume of $36.5 \mathrm{wt} \% \mathrm{HCl}$

$0.05 \mathrm{~mol} * 36.5 \mathrm{~g} / \mathrm{mol}=1.825 \mathrm{~g}$ of pure $\mathrm{HCl}$ 
$1.825 \mathrm{~g} / 36.5 \mathrm{wt} \%=5 \mathrm{~g}$ of $36.5 \mathrm{wt} \%$ hydrochloric solution

$5 \mathrm{~g} /(1.18 \mathrm{~g} / \mathrm{ml})=4.23 \mathrm{ml}$ of $36.5 \%$ hydrochloric solution

- Weight of ammonium bifluoride (ABF):

$0.05 \mathrm{~mol} \times 57(\mathrm{~g} / \mathrm{mol})=2.85 \mathrm{~g}$ of pure $\mathrm{ABF}$

$2.85 \mathrm{~g} / 95 \mathrm{wt} \%=3.0 \mathrm{~g}$ of ABF with purity of $95 \mathrm{wt} \%$

At the end, add water to the system to make the total weight as 200 grams.

\subsubsection{Clay solubility test in formic-HF acids}

Five acid fluids containing $9 \mathrm{wt} \%$ formic acid with different HF concentrations were prepared. To a $50 \mathrm{ml}$ plastic beaker, add $20 \mathrm{~g}$ of $9 \mathrm{wt} \%$ formic-HF acids and a magnetic stirring bar. Add $4 \mathrm{~g}$ of clay powder in to the acids, and then start stirring at room temperature. The details regarding acid compositions and clay types for each test are listed in Table 3.

Table 3 Acid composition and clay type for clay solubility test in formic-HF acids

\begin{tabular}{|c|c|c|}
\hline Test \# & Acid Composition & Clay \\
\hline F-0.5-K & $9 \mathrm{wt} \%$ formic-0.5 wt\% HF acids & Kaolinite \\
\hline F-1-K & $9 \mathrm{wt} \%$ formic-1 wt\% HF acids & Kaolinite \\
\hline F-2-K & $9 \mathrm{wt} \%$ formic-2 wt\% HF acids & Kaolinite \\
\hline F-3-K & $9 \mathrm{wt} \%$ formic-3 wt\% HF acids & Kaolinite \\
\hline F-6-K & $9 \mathrm{wt} \%$ formic-6 wt\% HF acids & Kaolinite \\
\hline F-0.5-C & $9 \mathrm{wt} \%$ formic-0.5 wt\% HF acids & Chlorite \\
\hline
\end{tabular}


Table 3 Continued

\begin{tabular}{|c|c|c|}
\hline Test \# & Acid Composition & Clay \\
\hline F-1-C & $9 \mathrm{wt} \%$ formic-1 wt\% HF acids & Chlorite \\
\hline F-2-C & $9 \mathrm{wt} \%$ formic-2 wt\% HF acids & Chlorite \\
\hline F-3-C & $9 \mathrm{wt} \%$ formic-3 wt\% HF acids & Chlorite \\
\hline F-6-C & $9 \mathrm{wt} \%$ formic-6 wt $\%$ HF acids & Chlorite \\
\hline F-0.5-I & $9 \mathrm{wt} \%$ formic-0.5 wt\% HF acids & Illite \\
\hline F-1-I & $9 \mathrm{wt} \%$ formic-1 wt $\%$ HF acids & Illite \\
\hline F-2-I & $9 \mathrm{wt} \%$ formic-2 wt $\%$ HF acids & Illite \\
\hline F-3-I & $9 \mathrm{wt} \%$ formic-3 $\mathrm{wt} \% \mathrm{HF}$ acids & Illite \\
\hline F-6-I & $9 \mathrm{wt} \%$ formic-6 wt $\%$ HF acids & \\
\hline
\end{tabular}

After stirring for 0.5 hour, filtrate the reaction suspension using plastic funnel and $0.2 \mu \mathrm{m}$ filter paper. The concentrations of $\mathrm{Si}, \mathrm{Al}, \mathrm{Ca}, \mathrm{Mg}, \mathrm{Fe}$ in filtrate were analyzed by inductively coupled plasma (ICP) analysis using Optima 7000 DV ICPOES system and WinLab $32^{\mathrm{TM}}$ software. The solid part was dried under room temperature, then analyzed by energy-dispersive X-ray spectroscopy (EDS), to obtain the element composition. 


\subsubsection{Core flood experiments on Berea and Bandera sandstone cores using formic-HF} acids

To investigate the effect of mineralogy on the outcome of acidizing, coreflood experiments were also conducted beside the clay solubility test.

The sandstone cores were first dried at $250^{\circ} \mathrm{F}$ for 5 hours, and then saturated with $5 \mathrm{wt} \%$ ammonium chloride for 2 hours under vacuum. The pore volume of the core was determined by dividing the weight difference of the saturated core and the dry core by the density of brine.

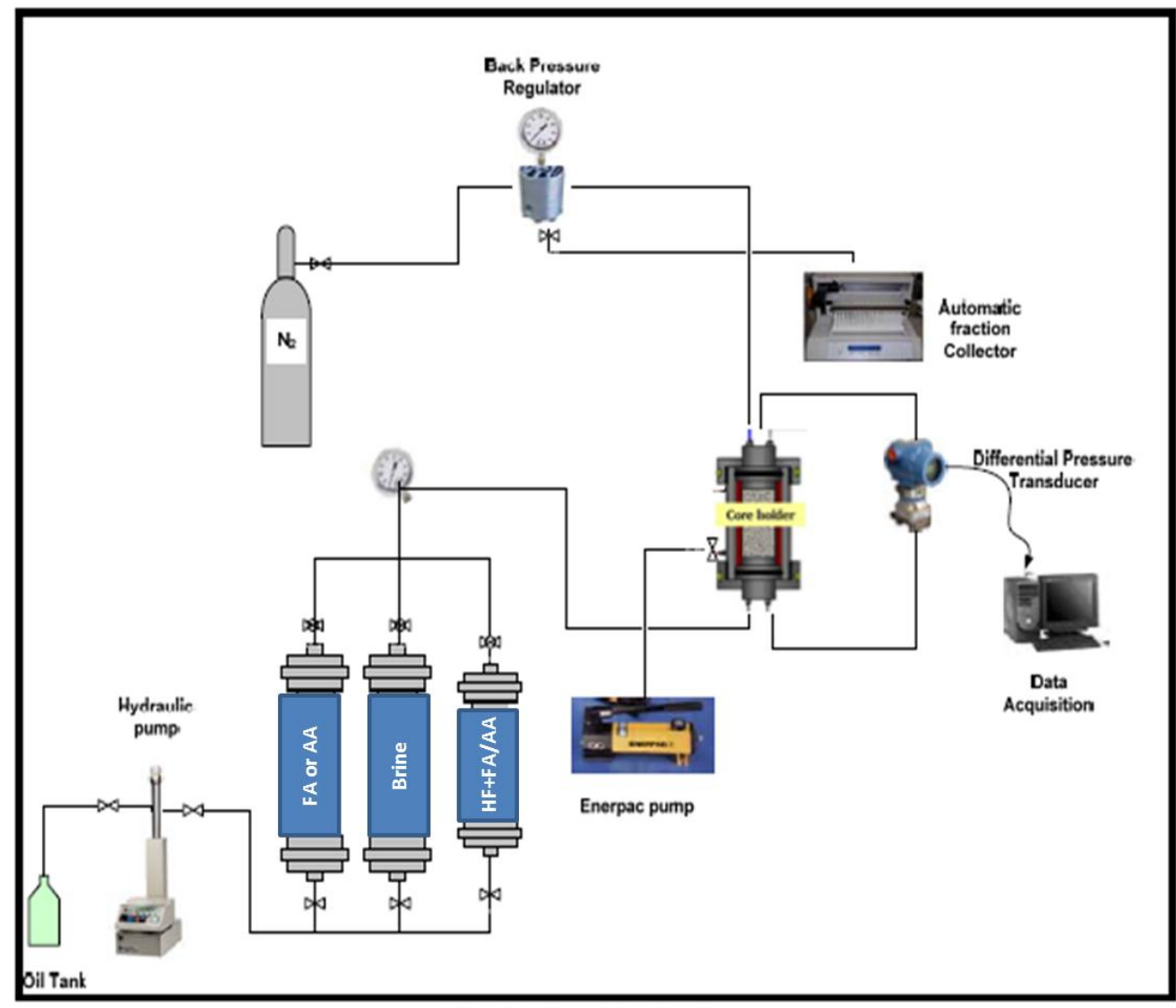

Fig. 4-Core flood experiment setup. 
The setup of the coreflood experiment is shown in Fig. 4. After the core was loaded into the core holder, the back pressure was adjusted to $1000 \mathrm{psi}$, while the overburden pressure was 2000 psi. The injection rate was $5 \mathrm{~cm}^{3} / \mathrm{min}$ in both experiments.

In all core flood experiments, $5 \mathrm{wt} \%$ ammonium chloride was injected to the core as preflush till the pressure drop was stablized, followed by acid preflush and then acid main flush. After these were acid post flush. At the end, $5 \mathrm{wt} \%$ ammonium chloride was injected as brine post flush till the pressure drop was stablized. The pressure drop at the beginning and end of the experiment were recored to calculate the initial and final permeability based on Darcy's Equation. Details regarding the coreflood experiment using formic-HF acids were listed in Table 4.

Table 4 Experimental conditions of core flood experiments on Berea and Bandera sandstone cores using formic-HF acids

\begin{tabular}{|c|r|c|}
\hline Experiment \# & F-1 & F-2 \\
\hline Sandstone Core Type & Berea sandstone core & Bandera sandstone core \\
\hline Acid Preflush & $9 \mathrm{wt} \%$ formic acid & $9 \mathrm{wt} \%$ formic acid \\
\hline Acid Main flush & $9 \mathrm{wt} \%$ formic- $1 \mathrm{wt} \% \mathrm{HF}$ acids & $9 \mathrm{wt} \%$ formic- 1 wt $\%$ HF acids \\
\hline Acid Post flush & $9 \mathrm{wt} \%$ formic acid & $9 \mathrm{wt} \%$ formic acid \\
\hline Temperature & & $75^{\circ} \mathrm{F}$ \\
\hline
\end{tabular}


The core effluent samples were collected and analyzed to determine the concentrations of $\mathrm{Ca}, \mathrm{Mg}, \mathrm{Fe}, \mathrm{Al}$, and $\mathrm{Si}$ by ICP analysis using Optima $7000 \mathrm{DV}$ ICPOES system and WinLab $32^{\mathrm{TM}}$ software.

\subsubsection{Core flood experiments on Berea sandstone cores using different amounts of HF}

To investigate the effect of HF amount on the outcome of acidizing, core flood experiments employing different concentrations or volumes of HF during main flush stage were conducted. The setup and conditions during the experiments are the same as described in 2.2.3. The details for each experiment are listed in Table 5.

Table 5 Experimental conditions of core flood experiments on Berea sandstone cores using different amounts of formic-HF acids

\begin{tabular}{|c|c|c|c|}
\hline Experiment \# & F-3 & F-4 & F-5 \\
\hline Acid preflush & $9 \mathrm{wt} \%$ formic acid & $9 \mathrm{wt} \%$ formic acid & $9 \mathrm{wt} \%$ formic acid \\
\hline Acid main flush & $9 \mathrm{wt} \%$ formic-1 wt $\% \mathrm{HF}$ & $9 \mathrm{wt} \%$ formic-2 wt $\%$ & $9 \mathrm{wt} \%$ formic-0.5 wt $\%$ \\
& acids & HF acids acids & 1 PV \\
\hline Acid main flush volume & $3 \mathrm{PV}$ & $3 \mathrm{PV}$ & $9 \mathrm{wt} \%$ formic acid \\
\hline Acid post flush & $9 \mathrm{wt} \%$ formic acid & $9 \mathrm{wt} \%$ formic acid & $75^{\circ} \mathrm{F}$ \\
\hline Temperature & $75^{\circ} \mathrm{F}$ & $75^{\circ} \mathrm{F}$ & \\
\hline
\end{tabular}


The core effluent samples were then collected and analyzed to determine the concentrations of $\mathrm{Ca}, \mathrm{Mg}, \mathrm{Fe}, \mathrm{Al}$, and Si by ICP analysis using Optima $7000 \mathrm{DV}$ ICPOES system and WinLab $32^{\mathrm{TM}}$ software. The sandstone cores were scanned by X-ray computed tomography (CT) both before and after the coreflood experiments. The CT results were analyzed utilizing ImageJ software.

\subsubsection{Core flood experiments on Berea sandstone cores under different temperatures}

To study the effect of temperature on the preflush stage using formic acid, core flood experiments on Berea sandstone cores were conducted under different temperatures using only formic acid. The setup and conditions during the experiments are the same as described in 2.2.3. The details for each experiment are listed in Table 6.

Table 6 Experimental conditions of core flood experiments on Berea sandstone cores under different temperatures using formic acid

\begin{tabular}{|c|c|c|}
\hline Experiment \# & F-6 & F-7 \\
\hline Acid preflush & $9 \mathrm{wt} \%$ formic acid & $9 \mathrm{wt} \%$ formic acid \\
\hline Acid preflush volume & $10 \mathrm{PV}$ & $10 \mathrm{PV}$ \\
\hline Acid main flush & N/A $/ \mathrm{A}$ \\
\hline Acid post flush & N/A & N/A \\
\hline Temperature & $75^{\circ} \mathrm{F}$ & $250^{\circ} \mathrm{F}$ \\
\hline
\end{tabular}


To investigate the effect of temperature on the outcome of acidizing, core flood experiments on Berea sandstone cores were conducted under different temperatures. The setup and conditions during the experiments are the same as described in 2.2.3. The details for each experiment are listed in Table 7.

Table 7 Experimental conditions of core flood experiments on Berea sandstone cores under different temperatures using formic-HF acids

\begin{tabular}{|c|c|c|c|}
\hline Experiment \# & F-8 & F-9 & F-10 \\
\hline Acid preflush & $9 \mathrm{wt} \%$ formic acid & $9 \mathrm{wt} \%$ formic acid & $9 \mathrm{wt} \%$ formic acid \\
\hline Acid main flush & $9 \mathrm{wt} \%$ formic-0.5 & $9 \mathrm{wt} \%$ formic-0.5 wt\% & $9 \mathrm{wt} \%$ formic-0.5 wt $\%$ \\
& wt\% HF acids & HF acids & HF acids \\
\hline Acid main flush volume & $1 \mathrm{PV}$ & $1 \mathrm{PV}$ & $1 \mathrm{PV}$ \\
\hline Acid post flush & $9 \mathrm{wt} \%$ formic acid & $9 \mathrm{wt} \%$ formic acid & $9 \mathrm{wt} \%$ formic acid \\
\hline Temperature & $150^{\circ} \mathrm{F}$ & $250^{\circ} \mathrm{F}$ & $350^{\circ} \mathrm{F}$ \\
\hline
\end{tabular}

The core effluent samples were then collected and analyzed to determine the concentrations of $\mathrm{Ca}, \mathrm{Mg}, \mathrm{Fe}, \mathrm{Al}$, and Si by ICP analysis using Optima 7000 DV ICPOES system and WinLab $32^{\mathrm{TM}}$ software. The sandstone cores were scanned by X-ray computed tomography (CT) both before and after the coreflood experiments. The CT results were analyzed utilizing ImageJ software. 


\subsection{Acetic-HF Acids}

\subsubsection{Preparation of 13 wt\% acetic-HF acids}

Acid fluids containing $13 \mathrm{wt} \%$ acetic acid with different concentrations of HF were also prepared. An example of preparation of $200 \mathrm{~g}$ of $13 \mathrm{wt} \%$ acetic- $1 \mathrm{wt} \% \mathrm{HF}$ is shown here.

To prepare $13 \mathrm{wt} \%$ acetic- $1 \mathrm{wt} \% \mathrm{HF}$ acids, acetic acid, hydrochloric acid, water, and ammonium bifluoride were needed.

- Necessary information

Water: density is $1 \mathrm{~g} / \mathrm{ml}$

Ammonium bifluoride: Molecular Weight (MW) is $57 \mathrm{~g} / \mathrm{mol}$

$$
\text { Purity is } 95 \mathrm{wt} \%
$$

Acetic acid: Purity is $99.7 \mathrm{wt} \%$

Density is $1.049 \mathrm{~g} / \mathrm{ml}$

Hydrochloric acid: Purity is $36.5 \mathrm{wt} \%$

Density is $1.18 \mathrm{~g} / \mathrm{ml}$

- Volume of $99.7 \%$ acetic acid needed

$200 \mathrm{~g} \times 13 \mathrm{wt} \%=26 \mathrm{~g}$ of pure formic acid

$26 \mathrm{~g} / 99.7 \mathrm{wt} \%=26.08 \mathrm{~g}$ of $96 \%$ formic acid

$26.08 \mathrm{~g} /(1.049 \mathrm{~g} / \mathrm{ml})=24.86 \mathrm{ml}$ of $99.7 \mathrm{wt} \%$ formic acid

- Molar mass of HF

$200 \mathrm{~g} \times 1 \%=2 \mathrm{~g} \mathrm{HF}$ 
$2 \mathrm{~g} /(20 \mathrm{~g} / \mathrm{mol})=0.1 \mathrm{~mol}$

Based on Eq. 2.1, $0.05 \mathrm{~mol}$ of $\mathrm{HCl}$ and $0.05 \mathrm{~mol}$ of ammonium bifluoride are needed.

- Volume of $36.5 \mathrm{wt} \% \mathrm{HCl}$

$0.05 \mathrm{~mol} \times 36.5 \mathrm{~g} / \mathrm{mol}=1.825 \mathrm{~g}$ of pure $\mathrm{HCl}$

$1.825 \mathrm{~g} / 36.5 \%=5 \mathrm{~g}$ of $36.5 \%$ hydrochloric solution

$5 \mathrm{~g} /(1.18 \mathrm{~g} / \mathrm{ml})=4.23 \mathrm{ml}$ of $36.5 \%$ hydrochloric solution

- Weight of ammonium bifluoride (ABF)

$0.05 \mathrm{~mol} \times 57(\mathrm{~g} / \mathrm{mol})=2.85 \mathrm{~g}$ of pure $\mathrm{ABF}$

$2.85 \mathrm{~g} / 95 \%=3.0 \mathrm{~g}$ of $95 \% \mathrm{ABF}$

At the end, add water to the system to make the total weight as 200 grams.

\subsubsection{Clay solubility test in acetic-HF acids}

The acid compositions and clays used in all the clay solubility tests in acetic-HF acids are listed in Table $\mathbf{8}$. All the experimental procedures are the same as described in 2.2.2.

Table 8 Acid composition and clay type for clay solubility test in acetic-HF acids

\begin{tabular}{|c|c|c|}
\hline Test \# & Acid Composition & Clay \\
\hline A-0.5-K & $13 \mathrm{wt} \%$ acetic- $0.5 \mathrm{wt} \%$ HF acids & Kaolinite \\
\hline A-1-K & $13 \mathrm{wt} \%$ acetic $-1 \mathrm{wt} \%$ HF acids & Kaolinite \\
\hline A-2-K & $13 \mathrm{wt} \%$ acetic $-2 \mathrm{wt} \%$ HF acids & Kaolinite \\
\hline
\end{tabular}


Table 8 Continued

\begin{tabular}{|c|c|c|}
\hline Test \# & Acid Composition & Clay \\
\hline A-3-K & $13 \mathrm{wt} \%$ acetic $-3 \mathrm{wt} \% \mathrm{HF}$ acids & Kaolinite \\
\hline A-6-K & $13 \mathrm{wt} \%$ acetic $-6 \mathrm{wt} \% \mathrm{HF}$ acids & Kaolinite \\
\hline A-0.5-C & $13 \mathrm{wt} \%$ acetic $-0.5 \mathrm{wt} \% \mathrm{HF}$ acids & Chlorite \\
\hline A-1-C & $13 \mathrm{wt} \%$ acetic $-1 \mathrm{wt} \% \mathrm{HF}$ acids & Chlorite \\
\hline $\mathrm{A}-2-\mathrm{C}$ & $13 \mathrm{wt} \%$ acetic $-2 \mathrm{wt} \% \mathrm{HF}$ acids & Chlorite \\
\hline A-3-C & $13 \mathrm{wt} \%$ acetic $-3 \mathrm{wt} \% \mathrm{HF}$ acids & Chlorite \\
\hline A-6-C & $13 \mathrm{wt} \%$ acetic $-6 \mathrm{wt} \% \mathrm{HF}$ acids & Chlorite \\
\hline A-0.5-I & $13 \mathrm{wt} \%$ acetic $-0.5 \mathrm{wt} \% \mathrm{HF}$ acids & Illite \\
\hline A-1-I & $13 \mathrm{wt} \%$ acetic $-1 \mathrm{wt} \% \mathrm{HF}$ acids & Illite \\
\hline A-2-I & $13 \mathrm{wt} \%$ acetic $-2 \mathrm{wt} \% \mathrm{HF}$ acids & Illite \\
\hline A-3-I & $13 \mathrm{wt} \%$ acetic $-3 \mathrm{wt} \% \mathrm{HF}$ acids & Illite \\
\hline
\end{tabular}

\subsubsection{Core flood experiments on Berea and Bandera sandstone cores using acetic-HF} acids

The setup, procedures and conditions of core flood experiments using acetic-HF acids are the same as described in 2.2.3 using formic-HF acids. The details of these two experiments are listed in Table 9. 
Table 9 Experimental conditions of core flood experiment using acetic-HF acids

\begin{tabular}{|c|c|c|}
\hline Experiment \# & A-1 & A-2 \\
\hline Sandstone core type & Berea sandstone core & Bandera sandstone core \\
\hline Acid preflush & $13 \mathrm{wt} \%$ formic acid & $13 \mathrm{wt} \%$ formic acid \\
\hline Acid main flush & $13 \mathrm{wt} \%$ formic- $1 \mathrm{wt} \% \mathrm{HF}$ acids & $13 \mathrm{wt} \%$ formic- $1 \mathrm{wt} \% \mathrm{HF}$ acids \\
\hline Acid post flush & $13 \mathrm{wt} \%$ formic acid & $13 \mathrm{wt} \%$ formic acid \\
\hline Temperature & $75^{\circ} \mathrm{F}$ & $75^{\circ} \mathrm{F}$ \\
\hline
\end{tabular}




\section{RESULTS AND DISCUSSIONS}

\subsection{Formic-HF Acids}

\subsubsection{Clay solubility in formic-HF acids}

After the reactions of kaolinite with $9 \mathrm{wt} \%$ formic acid and $\mathrm{HF}$, only $\mathrm{Si}$ and $\mathrm{Al}$ were detected in the spent acid solutions. This is because kaolinite is majorly composed of $\mathrm{Al}, \mathrm{Si}$, and $\mathrm{O}$ only (Table 1). Concentrations of $\mathrm{Si}$ and $\mathrm{Al}$ are shown in Fig. 5. With the increase of $\mathrm{HF}$ concentration, $\mathrm{Si}$ and $\mathrm{Al}$ concentrations in spent acids also increase. This indicate that more $\mathrm{Si}$ and $\mathrm{Al}$ were released by kaolinite in more concentrated $\mathrm{HF}$, thought the concentration of formic acid did not change. Besides, the concentrations of $\mathrm{Si}$ and $\mathrm{Al}$ were nearly proportional to $\mathrm{HF}$ concentration, and the molar ratio between $\mathrm{Si}$ and Al was nearly 1:1 in all these experiments. This indicates that only primary reaction occurred under the experiment condition, since the secondary and tertiary reactions can alter the $\mathrm{Si} / \mathrm{Al}$ ratio significantly. 


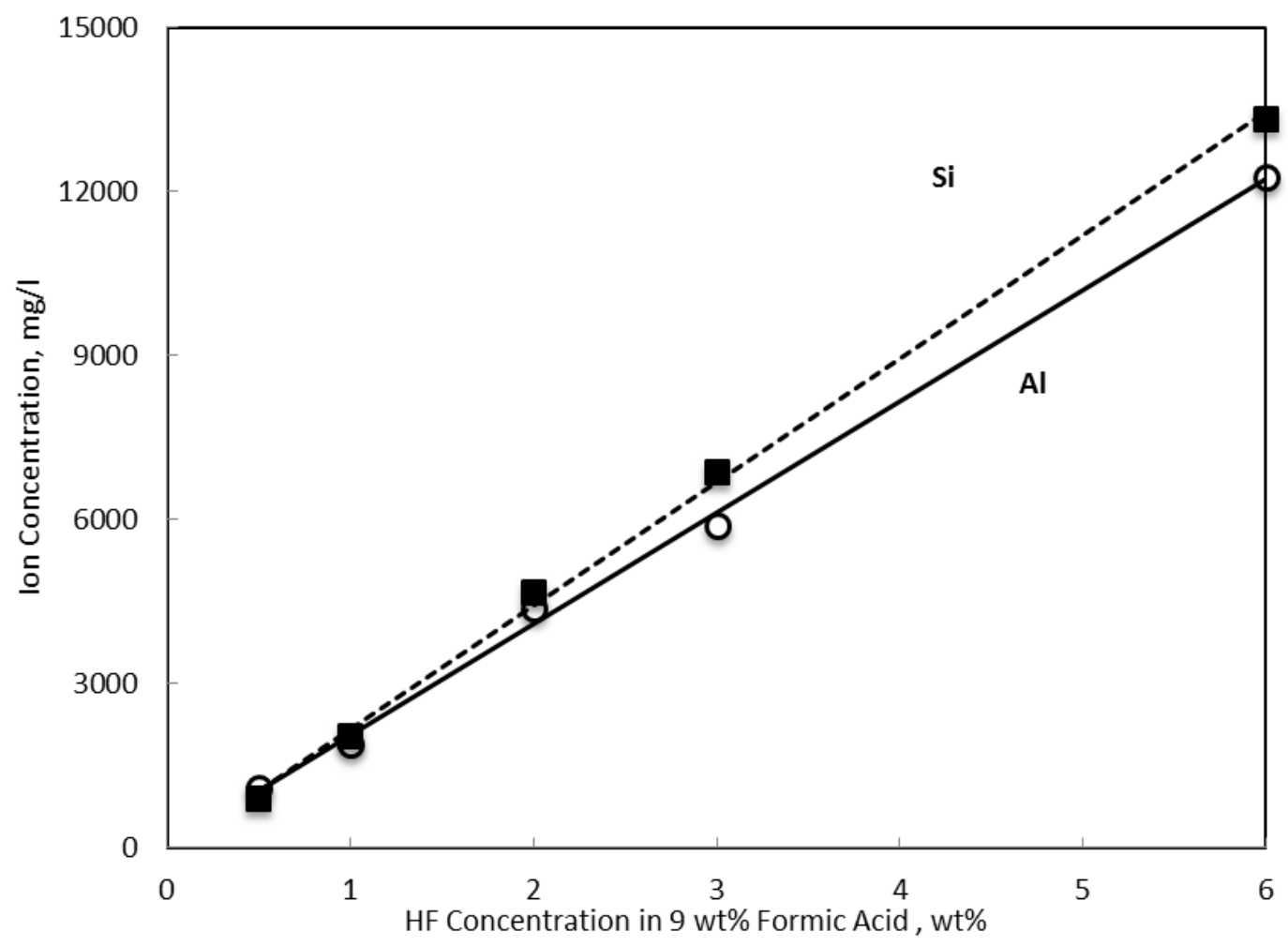

Fig. 5-Ion concentrations in $9 \mathrm{wt} \%$ formic-HF acid solutions after reactions with kaolinite at room temperature.

${ }^{19} \mathrm{~F}$ NMR spectra of $9 \mathrm{wt} \%$ formic acid $-0.5 \mathrm{wt} \% \mathrm{HF}$ after reaction with kaolinite is shown in Fig. 6. $\mathrm{CFCl}_{3}$ was used as a reference, of which the chemical shift is $0 \mathrm{ppm}$. To compare our results with literature reported values (Shuchart et al. 1995), we calculated the chemical shifts using trifluoro acetic acid $\left(\mathrm{CF}_{3} \mathrm{COOH}\right)$ as a reference first. $\mathrm{CF}_{3} \mathrm{COOH}$ has a chemical shift of $-76.55 \mathrm{ppm}$ relative to $\mathrm{CFCl}_{3}$ (Dungan et al. 1970). Therefore, the chemical shift in our spectra should $+76.55 \mathrm{ppm}$ to be the chemical shift relative to $\mathrm{CF}_{3} \mathrm{COOH}$. 
In the ${ }^{19} \mathrm{~F}$ NMR spectrum of $9 \mathrm{wt} \%$ formic acid $-0.5 \mathrm{wt} \% \mathrm{HF}$ after reaction with kaolinite (Fig. 6), there are two groups of signals in the spectrum, one is between -130 to $-132 \mathrm{ppm}$, and the other one is between -157 to $-159 \mathrm{ppm}$. As described before, these chemical shifts can be converted to nearly -54.45 and $-81.45 \mathrm{ppm}$, respectively, if we use $\mathrm{CF}_{3} \mathrm{COOH}$ as a reference. These values are very close to the values reported by Shuchart and Buster (1995). In their paper, they assigned the group of peaks near $-53 \mathrm{ppm}$ as silicon fluoride species, while those near $-80 \mathrm{ppm}$ as aluminum fluoride species. Based on their conclusions, and our ICP results, these two groups of peaks were assigned to belong to silicon fluorides and aluminum fluorides respectively. It is reported that HF had a chemical shift at $-85.5 \mathrm{ppm}$ (Shuchart et al 1995). However, there is no peak in that region in Fig. 6. Therefore it can be concluded that when the weight ratio between kaolinite and $9 \mathrm{wt} \%$ formic- $0.5 \mathrm{wt} \% \mathrm{HF}$ acids is $1: 5$, HF was completely consumed after 0.5 hour at room temperature, and both aluminum fluoride and silicon fluoride species were produced.

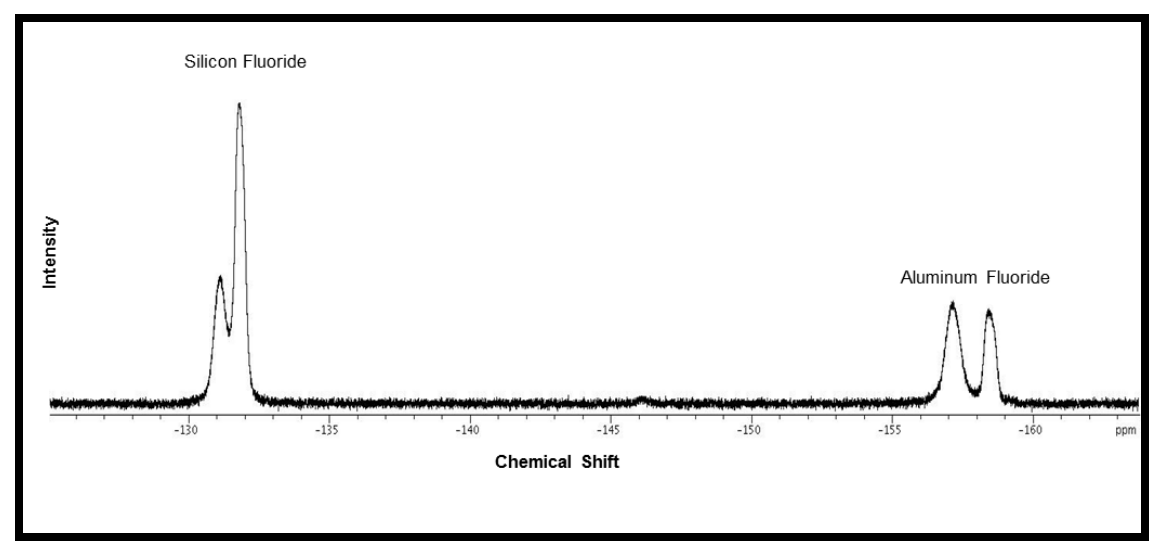

Fig. 6- ${ }^{19} \mathrm{~F}$ NMR spectrum of $9 \mathrm{wt} \%$ formic acid- $0.5 \mathrm{wt} \% \mathrm{HF}$ after reaction with kaolinite for 0.5 hour at $75^{\circ} \mathrm{F}$. 
After the reactions of acetic-HF acids with chlorite and illite (Figs. 7 and 8), Si and Fe were the major metal ions that were found in the spent acid solutions. Almost no $\mathrm{Al}$ was detected in all the experiments, though $\mathrm{Al}$ is a major element composition in chlorite and illite (Table 1). The absence of Al in spent acid could be caused by either the 2:1 structure of chlorite and illite, which makes the Al not very accessible, or the competition from Fe, which can form complex with F also (Al-harbi et al. 2011).

Besides, concentrations of Si and Fe increased when we brought up HF concentration, and $\mathrm{Si}$ increased more rapidly than Fe did.

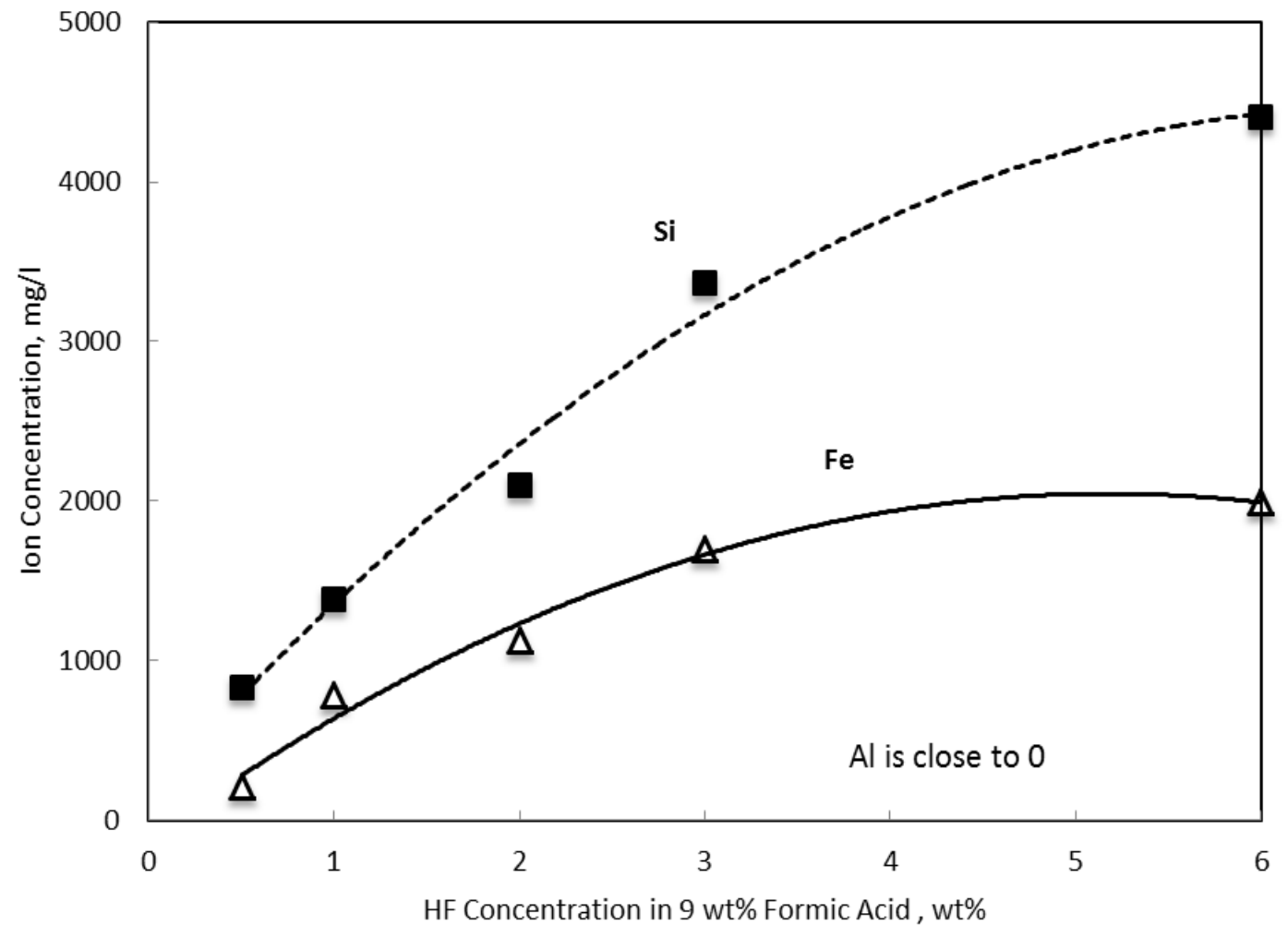

Fig. 7-Ion concentrations in $9 \mathrm{wt} \%$ formic-HF acid solutions after reactions with chlorite at room temperature. 


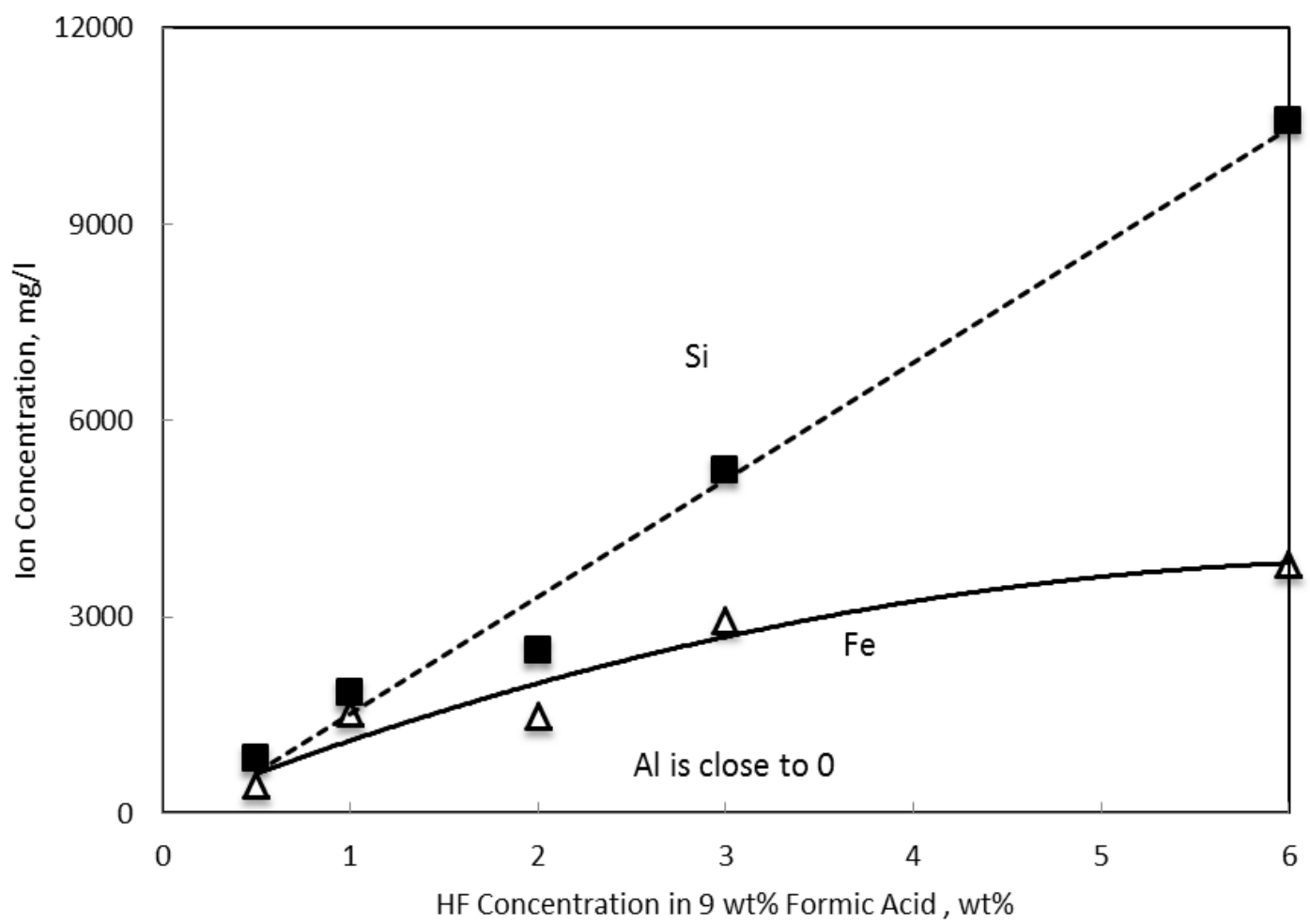

Fig. 8-Ion concentrations in $9 \mathrm{wt} \%$ formic-HF acid solutions after reactions with illite at room temperature.

In the ${ }^{19} \mathrm{~F}$ NMR spectra of $9 \mathrm{wt} \%$ formic acid $-0.5 \mathrm{wt} \% \mathrm{HF}$ after reaction with chlorite and illite (Figs. 9 and 10), the major peaks are noted in the region of -126 to $129 \mathrm{ppm}$. These indicate that most of the fluoride ions are coordinated with silicon. Also, no HF peak is observed, which means that HF was completely consumed. It can be concluded that HF was completely consumed, and silicon fluoride species were the major products. 


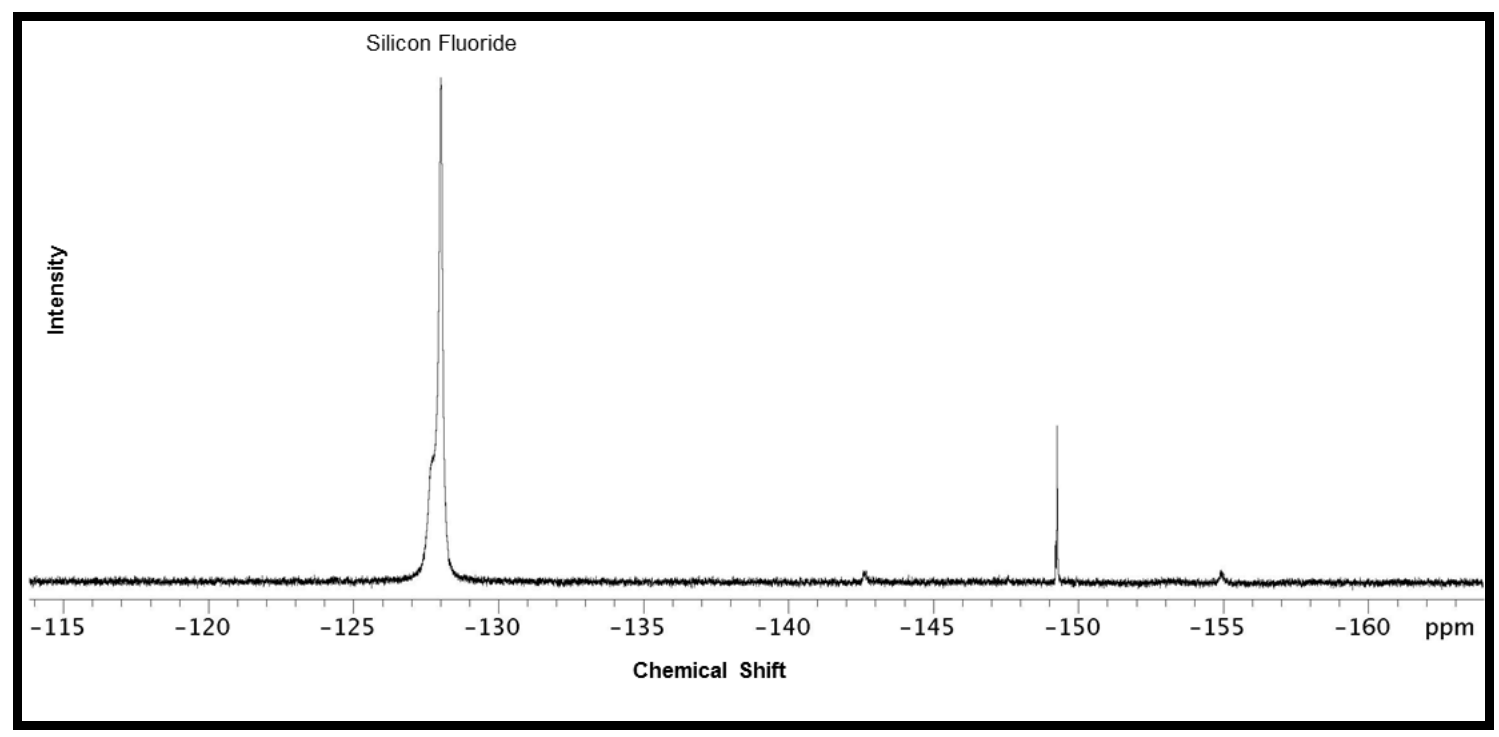

Fig. 9- ${ }^{19} \mathrm{~F}$ NMR spectrum of $9 \mathrm{wt} \%$ formic acid-0.5 wt $\%$ HF after reaction with chlorite for 0.5 hour at $75^{\circ} \mathrm{F}$.

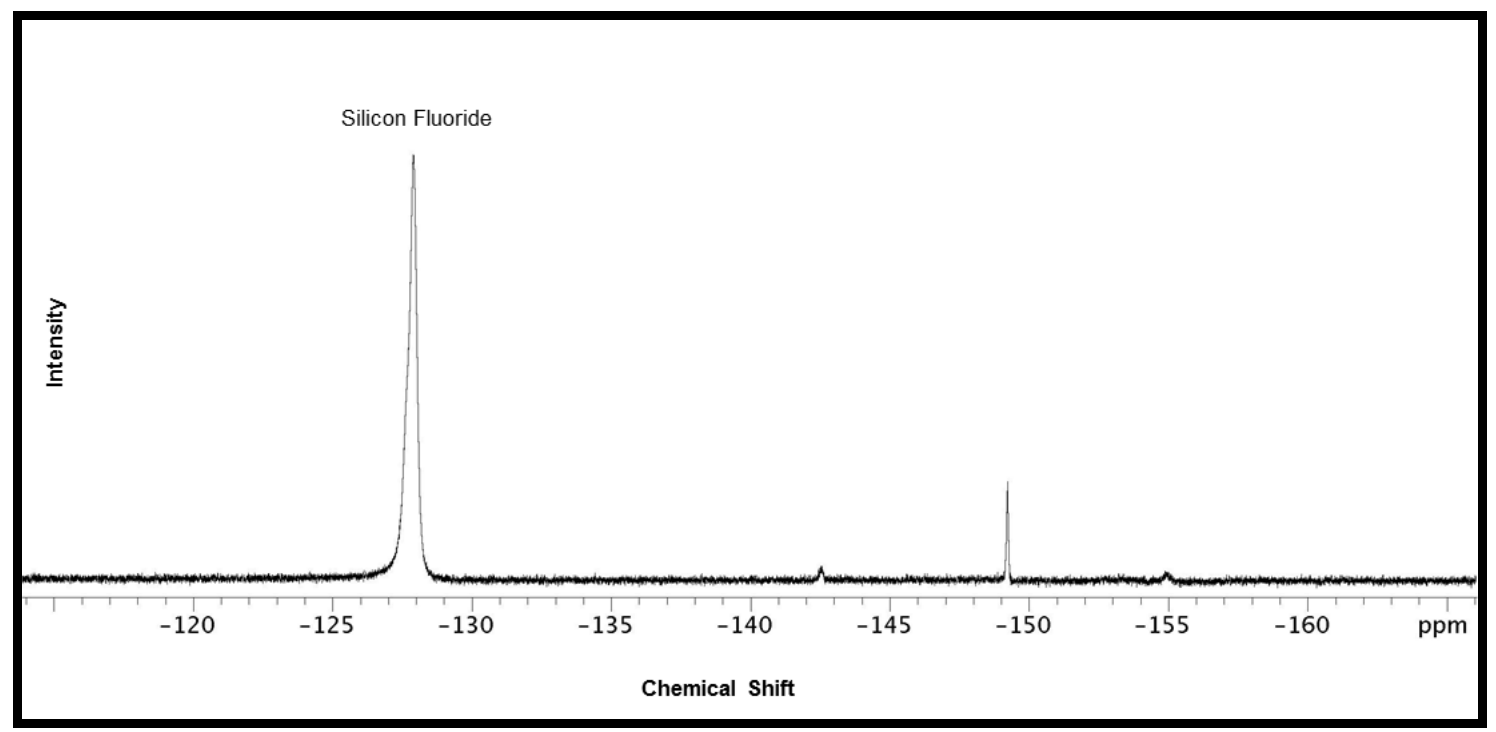

Fig. 10 - ${ }^{19}$ F NMR spectrum of $9 \mathrm{wt} \%$ formic acid- $0.5 \mathrm{wt} \% \mathrm{HF}$ after reaction with illite for 0.5 hour at $75^{\circ} \mathrm{F}$. 


\subsubsection{Core flood experiments on Berea and Bandera sandstone cores using formic-HF} acids

Core flood experiments were conducted on both Berea and Bandera sandstone cores, which have different mineralogy. The pressure drop during each core flood experiments is shown in Fig. 11 and Fig. 12.

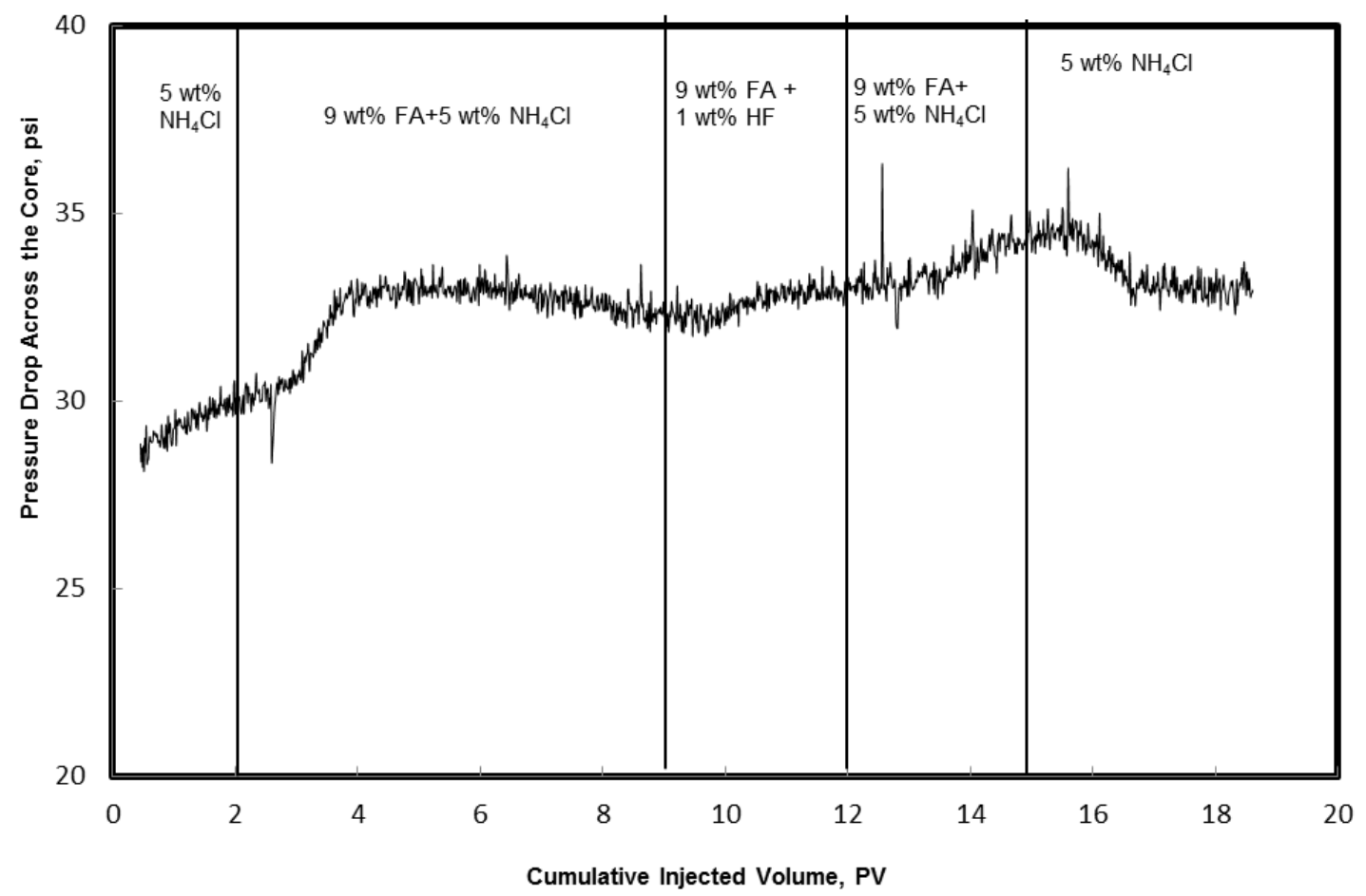

Fig. 11-Pressure drop across the core using $9 \mathrm{wt} \%$ formic acid with $5 \mathrm{wt} \%$ ammonium chloride as a preflush and $3 \mathrm{PV}$ of $9 \mathrm{wt} \%$ formic acid and $1 \mathrm{wt} \% \mathrm{HF}$ as the main flush at $75^{\circ} \mathrm{F}$ and $5 \mathrm{~cm}^{3} / \mathrm{min}$ on a Berea sandstone core. 


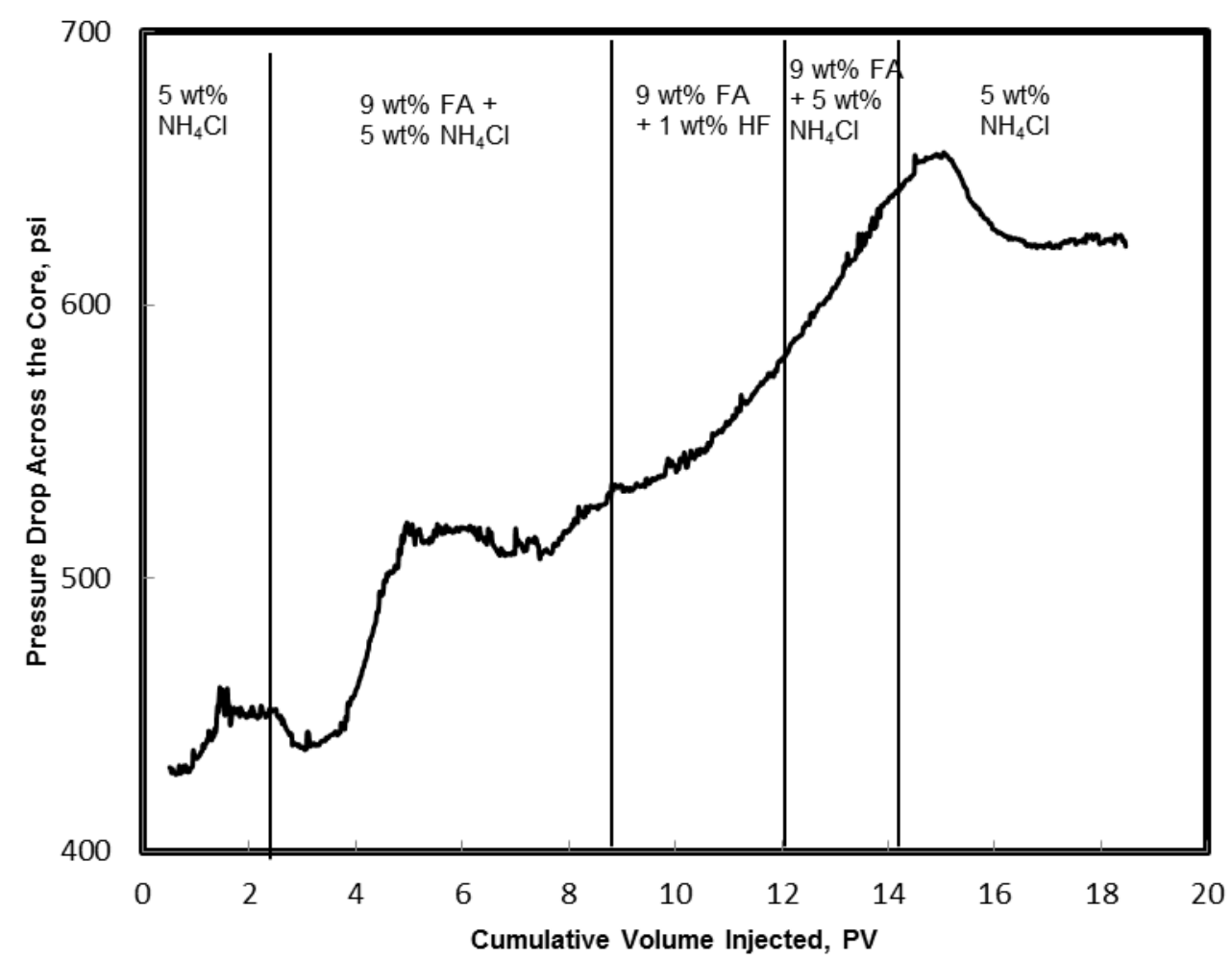

Fig. 12-Pressure drop across the core using $9 \mathrm{wt} \%$ formic acid with $5 \mathrm{wt} \%$ ammonium chloride as a preflush and $3 \mathrm{PV}$ of $9 \mathrm{wt} \%$ formic acid and $1 \mathrm{wt} \% \mathrm{HF}$ as the main flush at $75^{\circ} \mathrm{F}$ and $5 \mathrm{~cm}^{3} / \mathrm{min}$ on a Bandera sandstone core.

Concentrations of ions in effluent samples collected during both core flood experiments were shown in Figs. 13 and 14. In the core flood experiment on Berea sandstone (Fig. 13), the concentrations of $\mathrm{Si}$ and Al were very low during the acid preflush stage. This indicated that formic acid does not react with clay minerals at all. Since the injection of $9 \mathrm{wt} \%$ formic- $1 \mathrm{wt} \% \mathrm{HF}$ acids, both $\mathrm{Si}$ and $\mathrm{Al}$ concentrations increased quickly. Si concentration reached as high as $1,500 \mathrm{mg} / \mathrm{l}$, while $\mathrm{Al}$ 
concentration also rose up to $1,000 \mathrm{mg} / \mathrm{l}$. This indicates that the clay minerals inside the Berea sandstone core reacted with HF in the main flush stage.

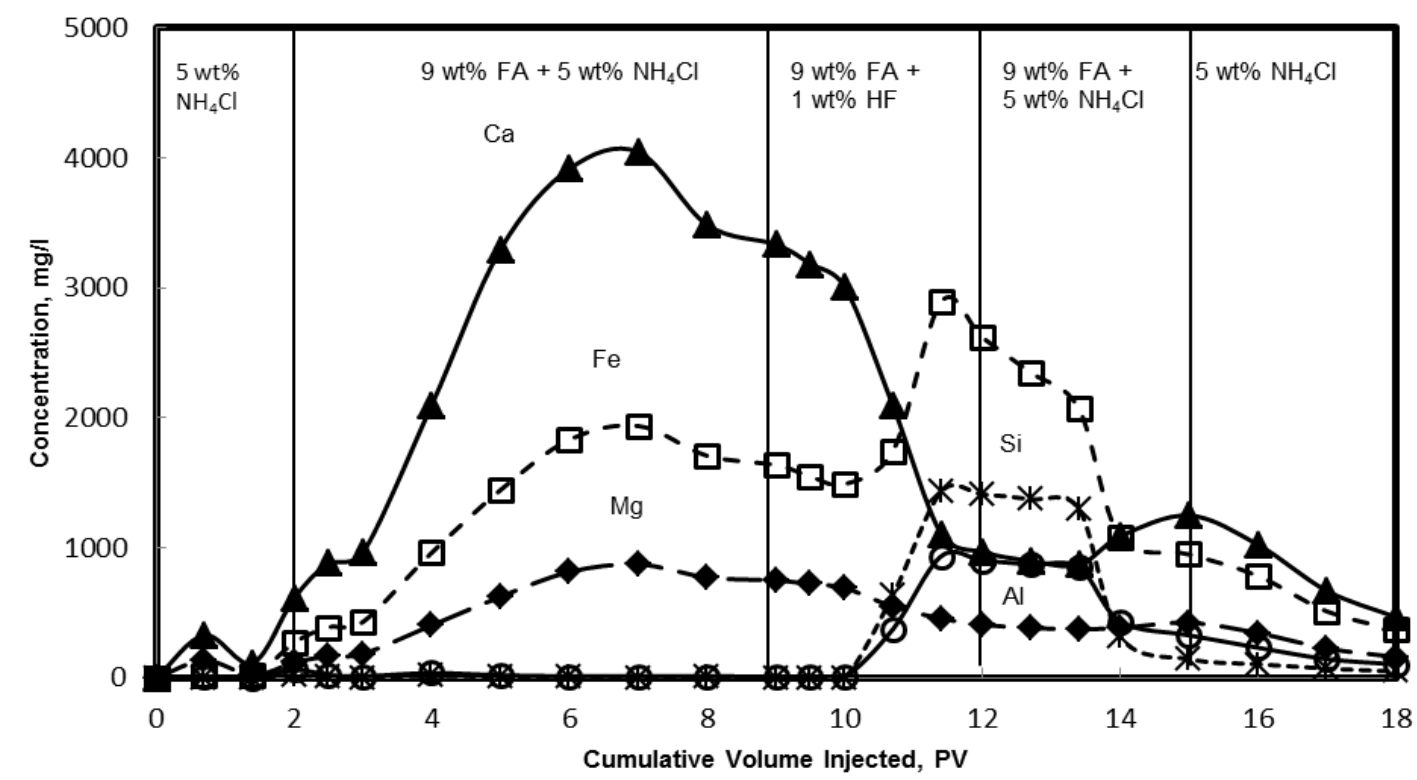

Fig. 13-Analysis of coreflood effluent samples for a Berea sandstone core treated by $9 \mathrm{wt} \%$ formic acid with $5 \mathrm{wt} \%$ ammonium chloride as a preflush and $3 \mathrm{PV}$ of $9 \mathrm{wt} \%$ formic acid with $1 \mathrm{wt} \% \mathrm{HF}$ as the main flush at $75^{\circ} \mathrm{F}$ and $5 \mathrm{~cm}^{3} / \mathrm{min}$.

However, in the core flood experiment on the Bandera sandstone core, $\mathrm{Si}$ concentration reached as high as $1,000 \mathrm{mg} / \mathrm{l}$ during the main flush stage, while $\mathrm{Al}$ concentration was very low during the whole experiment (Fig. 14). This difference in $\mathrm{Al}$ and $\mathrm{Si}$ concentrations can be explained by the mineralogy differences of these two cores. As shown in Table 2, Berea sandstone core has high percentage of kaolinite (5\%) and low percentages of chlorite $(2 \%)$ and illite (1\%). When treated by HF, kaolinite can 
release large and nearly equal amounts of $\mathrm{Si}$ and $\mathrm{Al}$, while chlorite and illite can only release $\mathrm{Si}$. So the overall effect is that $\mathrm{Si}$ concentration was a little higher than $\mathrm{Al}$ concentration during the main flush stage. In the Bandera sandstone core, the major clay mineral is illite, which can release large amount of Si when treated by HF, but no Al. As a result, the concentration of $\mathrm{Si}$ was very high during the main flush stage in the core flood experiment on the Bandera sandstone core, while Al concentration was very low.

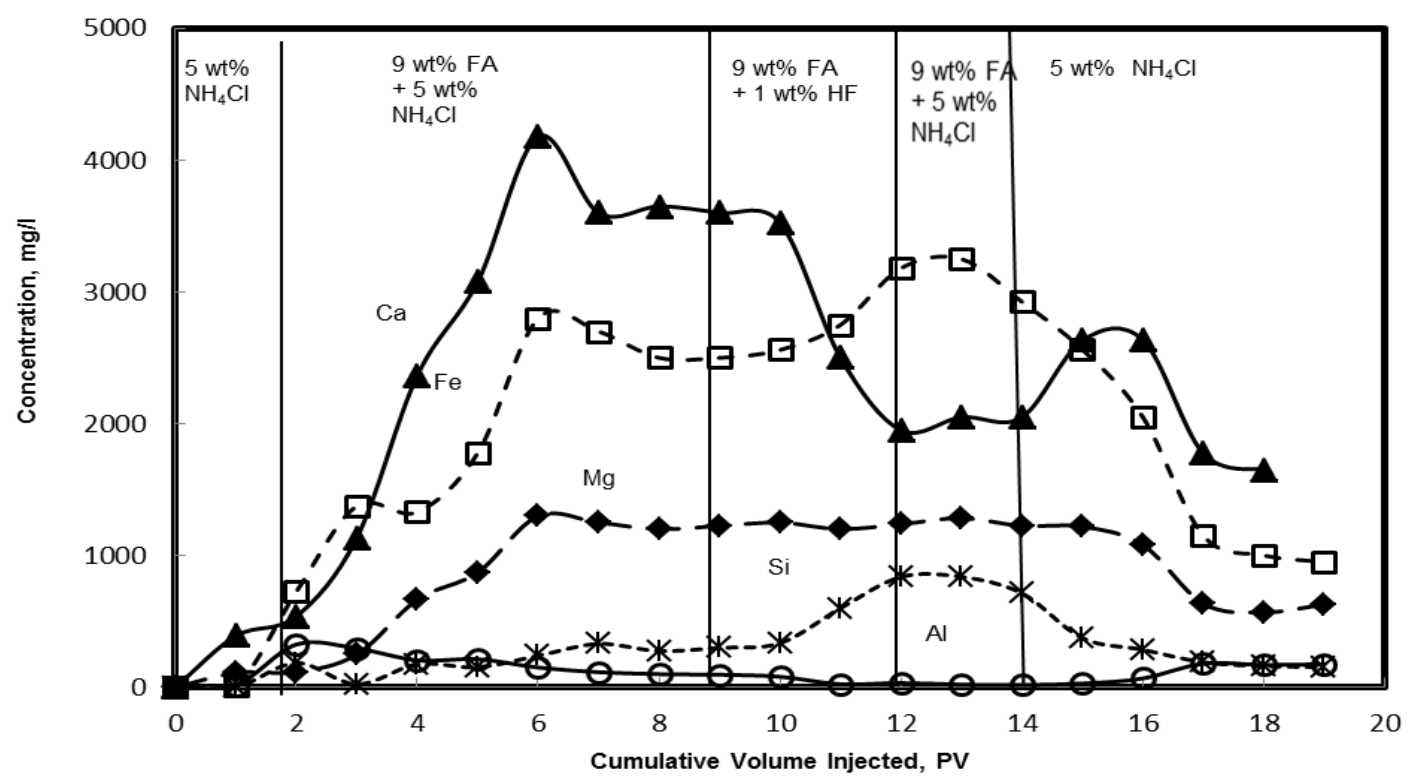

Fig. 14-Analysis of core flood effluent samples for a Bandera sandstone core treated by $9 \mathrm{wt} \%$ formic acid with $5 \mathrm{wt} \%$ ammonium chloride as a preflush and $3 \mathrm{PV}$ of $9 \mathrm{wt} \%$ formic- $1 \mathrm{wt} \% \mathrm{HF}$ as the main flush at $75^{\circ} \mathrm{F}$ and $5 \mathrm{~cm}^{3} / \mathrm{min}$. 


\subsubsection{Core flood experiments on Berea sandstone cores using different amount of HF}

To investigate the impact of HF amount on the outcome of acidizing, core flood experiments F-3 through F-4 were conducted (Table 5). In core flood experiment F-3, 3 pore volumes of $1 \mathrm{wt} \% \mathrm{HF}$ and $9 \mathrm{wt} \%$ formic acid were used in the main flush stage. It was noticed that the concentration of $\mathrm{Ca}$ suddenly dropped when the formic-HF acids were injected (Fig. 15). This indicated that Ca precipitated during this stage, and caused the permeability to decrease from 55 to $50 \mathrm{md}$ (Fig. 16). On the other hand, the highest concentrations of Si and $\mathrm{Al}$ were 1,300 and $600 \mathrm{mg} / \mathrm{l}$, respectively (Fig. 15), and these came from the reaction of aluminosilicates with $\mathrm{HF}$, which produced soluble silicon and aluminum fluorides.

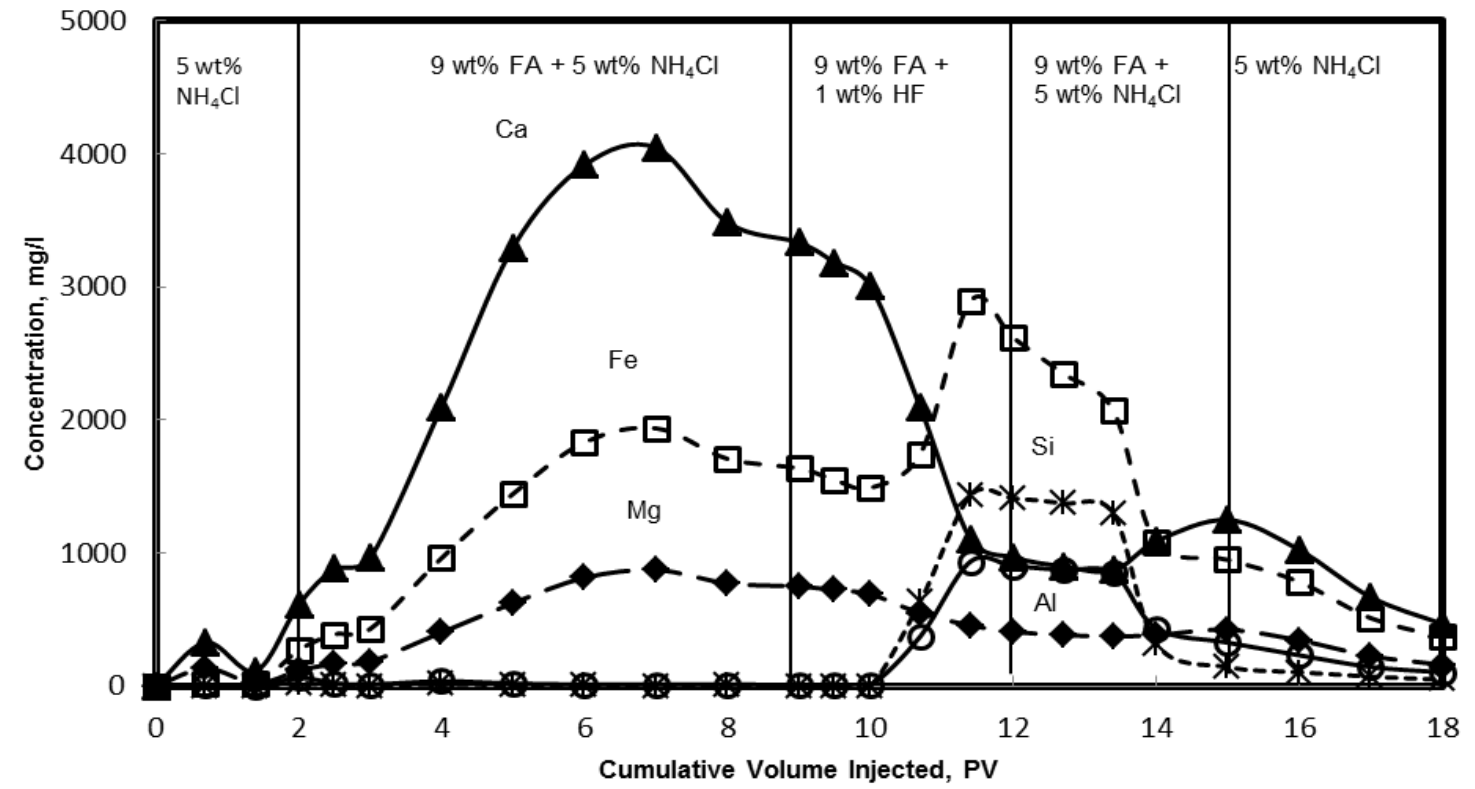

Fig. 15-Analysis of coreflood effluent samples for a Berea sandstone core treated by $9 \mathrm{wt} \%$ formic acid with $5 \mathrm{wt} \%$ ammonium chloride as a preflush and $3 \mathrm{PV}$ of $9 \mathrm{wt} \%$ formic acid with $1 \mathrm{wt} \% \mathrm{HF}$ as the main flush at $75^{\circ} \mathrm{F}$ and $5 \mathrm{~cm}^{3} / \mathrm{min}$. 


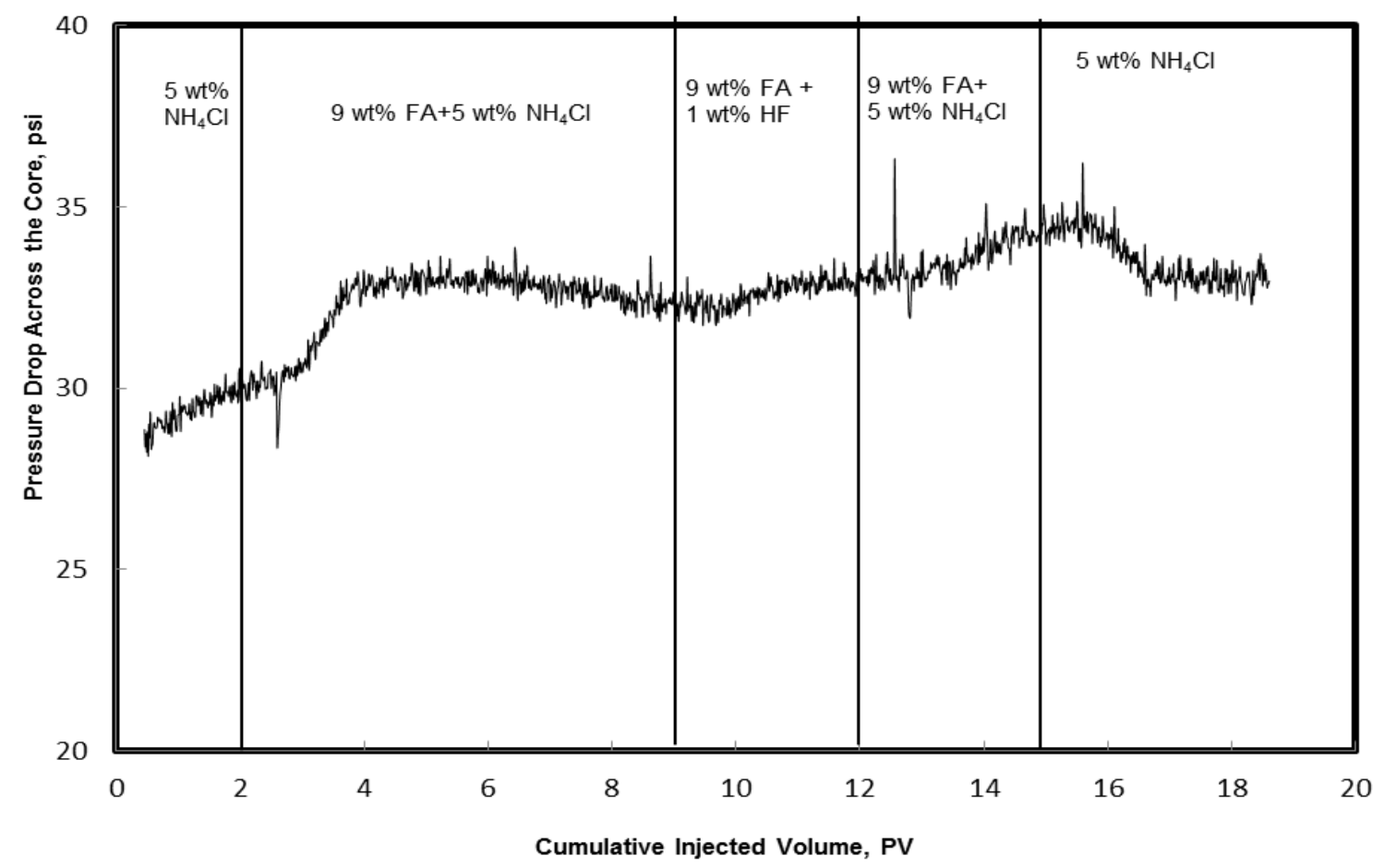

Fig. 16-Pressure drop across the core using $9 \mathrm{wt} \%$ formic acid with $5 \mathrm{wt} \%$ ammonium chloride as a preflush and $3 \mathrm{PV}$ of $9 \mathrm{wt} \%$ formic acid and $1 \mathrm{wt} \% \mathrm{HF}$ as the main flush at $75^{\circ} \mathrm{F}$ and $5 \mathrm{~cm}^{3} / \mathrm{min}$ on a Berea sandstone core.

In core flood experiment F-4, $2 \mathrm{wt} \% \mathrm{HF}$ and $9 \mathrm{wt} \%$ formic acid were used in the main flush. The highest concentrations of Si and Al were 3,500 and 1,700 mg/l (Fig.17), respectively, which were both much higher than in coreflood experiment F-3 (Fig.15). Therefore, it can be concluded that a higher concentration of HF is more effective in removing the aluminosilicates. As in experiment F-3, the concentration of Ca decreased significantly during this stage. Meanwhile, more damage was observed at the same time when the permeability decreased from 54 to 43 md (Fig. 18). 


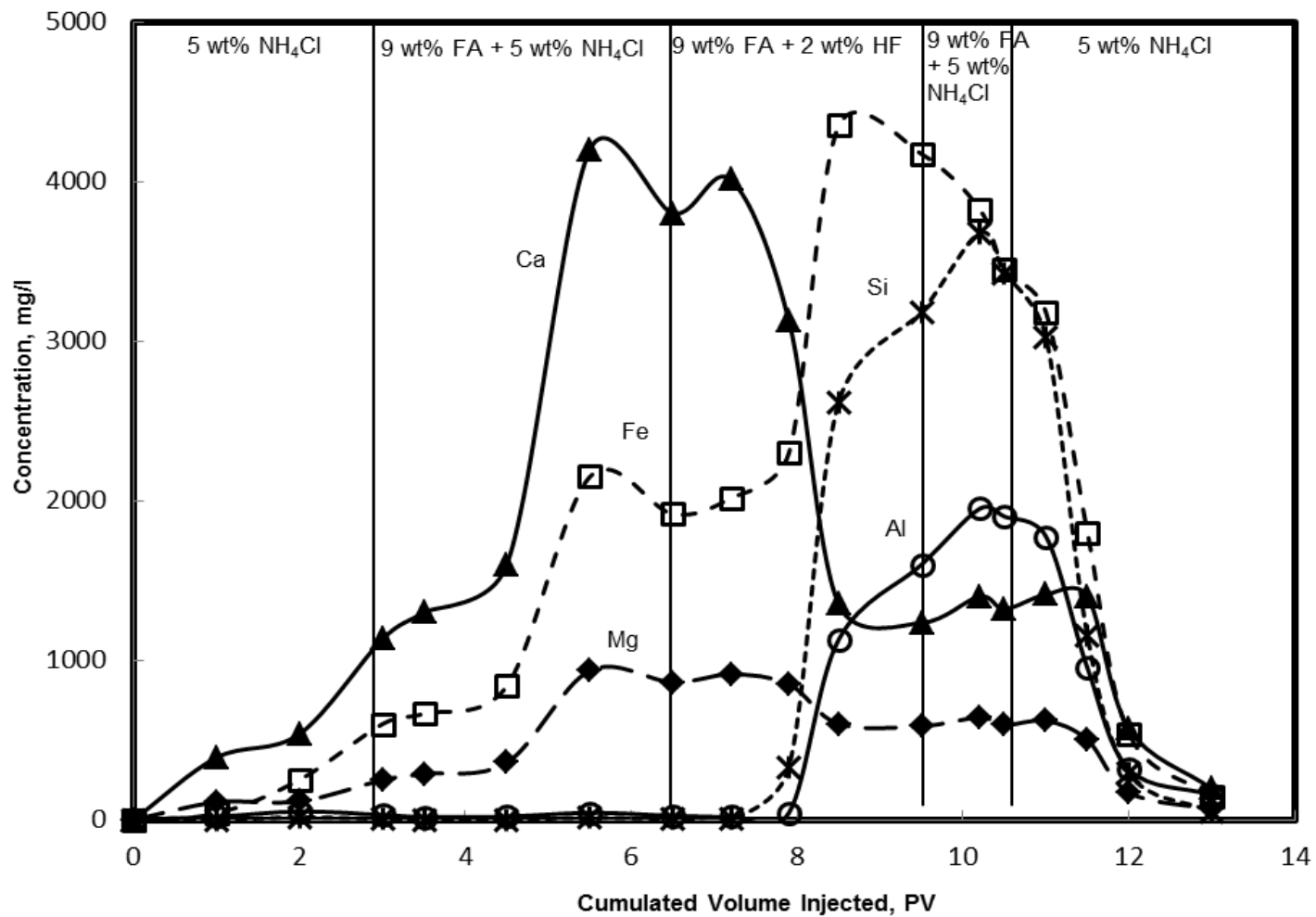

Fig. 17-Analysis of coreflood effluent samples for a Berea sandstone core treated by $9 \mathrm{wt} \%$ formic acid with $5 \mathrm{wt} \%$ ammonium chloride as a preflush and $3 \mathrm{PV}$ of $9 \mathrm{wt} \%$ formic acid with $2 \mathrm{wt} \% \mathrm{HF}$ as the main flush at $75^{\circ} \mathrm{F}$ and $5 \mathrm{~cm}^{3} / \mathrm{min}$. 


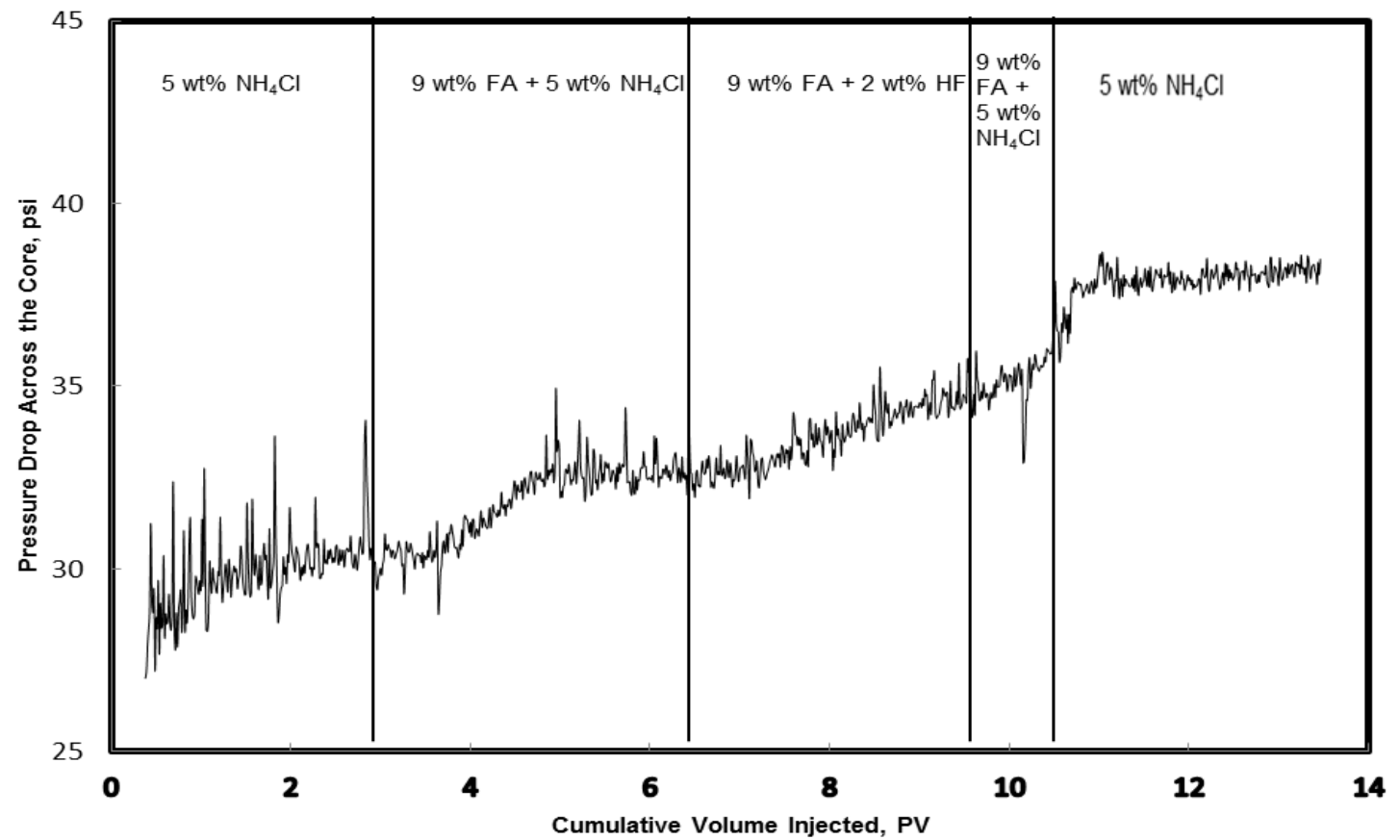

Fig. 18-Pressure drop across the core using $9 \mathrm{wt} \%$ formic acid with $5 \mathrm{wt} \%$ ammonium chloride as a preflush and $3 \mathrm{PV}$ of $9 \mathrm{wt} \%$ formic acid and $2 \mathrm{wt} \% \mathrm{HF}$ as the main flush at $75^{\circ} \mathrm{F}$ and $5 \mathrm{~cm}^{3} / \mathrm{min}$ on a Berea sandstone core.

CT number increases were observed both in coreflood experiments \#3 and \#4

(Figs. 19 and 20). 


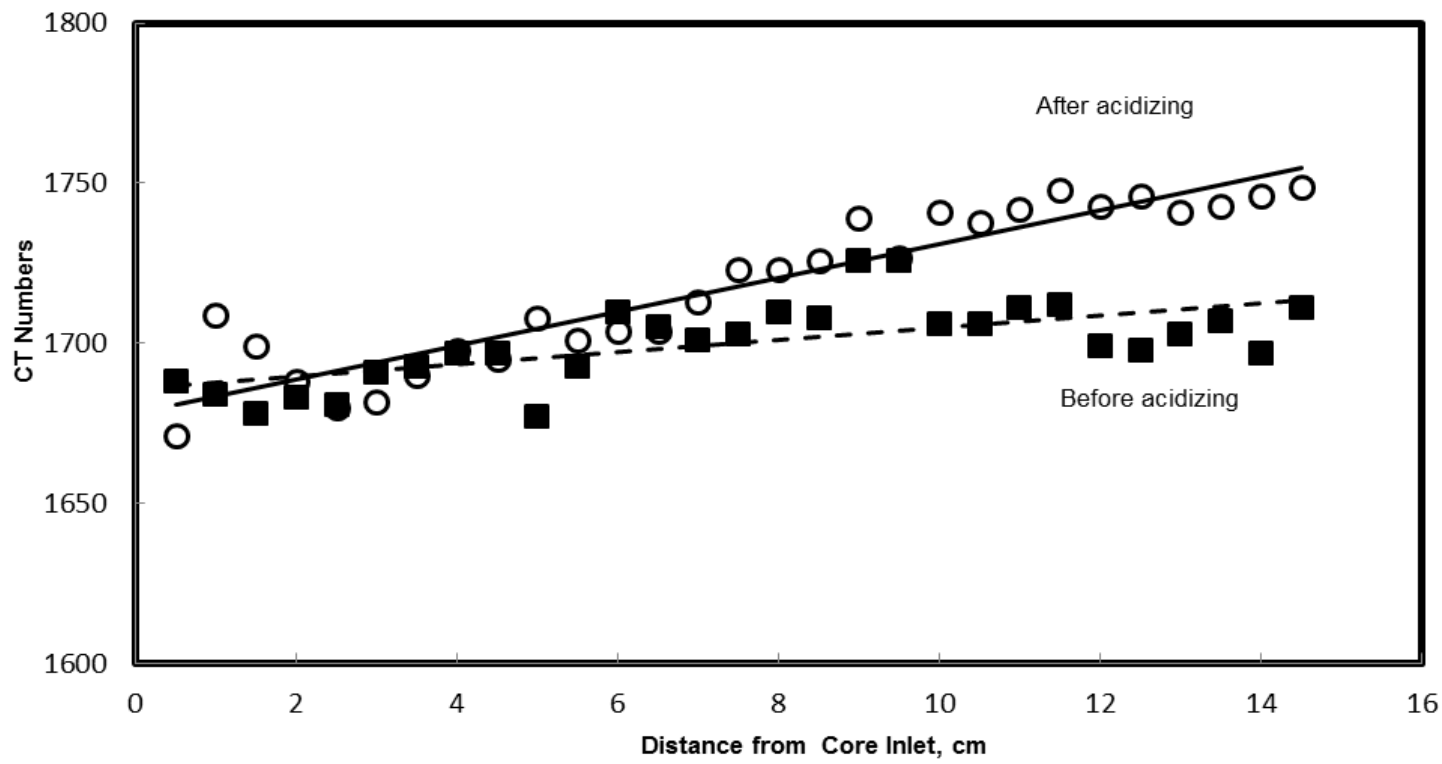

Fig. 19-CT number across the Berea sandstone core before and after the acid treatment using $9 \mathrm{wt} \%$ formic acid with $5 \mathrm{wt} \%$ ammonium chloride as a preflush and $3 \mathrm{PV}$ of $9 \mathrm{wt} \%$ formic acid with $1 \mathrm{wt} \% \mathrm{HF}$ as the main flush at $75^{\circ} \mathrm{F}$ and $5 \mathrm{~cm}^{3} / \mathrm{min}$.

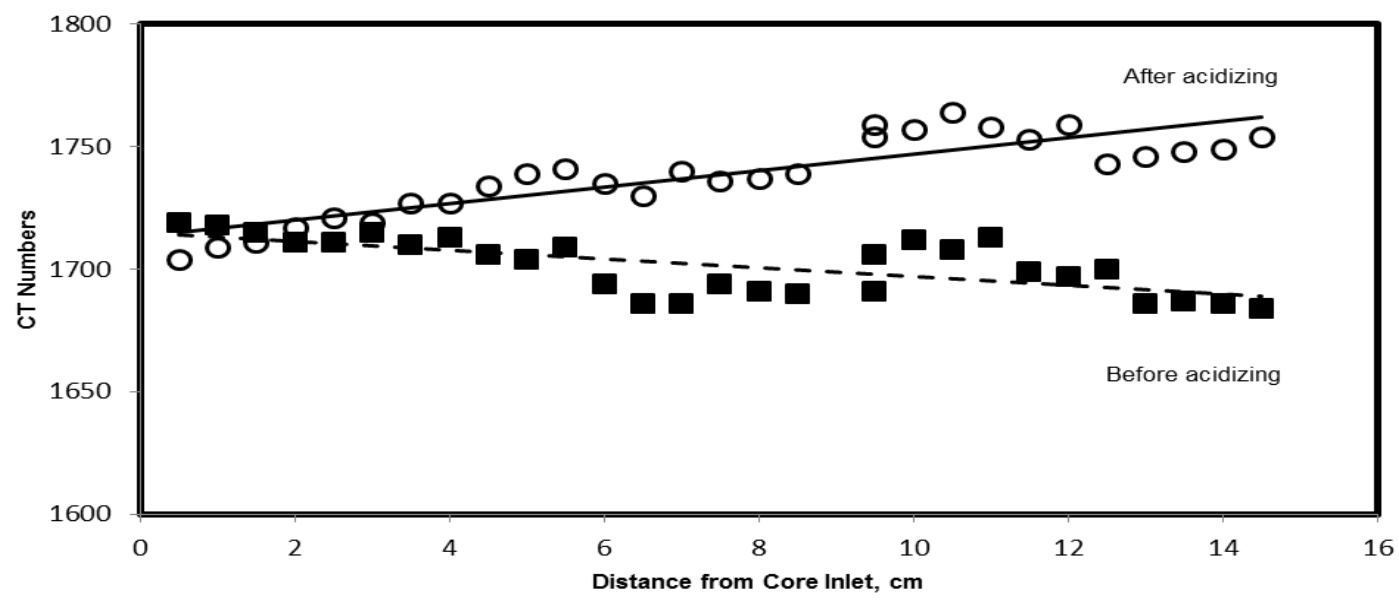

Fig. 20-CT number across the Berea sandstone core before and after the acid treatment using $9 \mathrm{wt} \%$ formic acid with $5 \mathrm{wt} \%$ ammonium chloride as a preflush and $3 \mathrm{PV}$ of $9 \mathrm{wt} \%$ formic acid with $2 \mathrm{wt} \% \mathrm{HF}$ as the main flush at $75^{\circ} \mathrm{F}$ and $5 \mathrm{~cm}^{3} / \mathrm{min}$.

The CT number is related to the bulk density as shown in Eq. 9 (Izgec 2009).

$$
\rho_{\text {bulk }}=a C T N+b
$$


Where $\rho_{\text {bulk }}$ is the bulk density, $C T N$ represents the CT number, $a$ is the slope, and $b$ is the intercept of the linear relation between $C T N$ and the bulk density.

The higher CT numbers after the acid treatment indicated that higher-density precipitate was formed inside the core. The increase in CT number became larger towards the outlet of core, which means that precipitate accumulated while HF was consumed. Also, formic acid was not able to maintain the solubility of reaction products. It is known that $\mathrm{CaF}_{2}$, has a density of $3.18 \mathrm{~g} / \mathrm{cm}^{3}$, which is larger than that of sandstone $\left(2.65 \mathrm{~g} / \mathrm{cm}^{3}\right)$ (Perry 2011). Besides, $\mathrm{CaF}_{2}$ has ever been reported as precipitation when HF was pumped down hole and mixed with spent acid there, which has high concentration of $\mathrm{Ca}$ (Mohammad et al. 2011). Combining with the sudden drop of Ca after injection of formic-HF acids, it can be inferred that Ca precipitated in the form of $\mathrm{CaF}_{2}$.

To further confirm the hypothesis of $\mathrm{CaF}_{2}$ precipitate, coreflood experiments $\mathrm{F}-5$ was conducted. It employed 1 PV of $9 \mathrm{wt} \%$ formic acid $-0.5 \mathrm{wt} \% \mathrm{HF}$. Compared with coreflood experiment F-3, the fluoride amount in this experiment was much smaller, also the extent of mixing the spent acid containing $\mathrm{Ca}$ with the solution containing fluoride ions was reduced. If the hypothesis regarding the $\mathrm{CaF}_{2}$ precipitate was true, less permeability loss should be achieved. And this is the case in core flood experiment F-5, where the permeability only slightly decreased from 62 to $60 \mathrm{md}$ (Fig. 21). Less Ca concentration drop was observed after the injection of HF at the same time(Fig. 22). This proved that $\mathrm{Ca}$ did precipitate in the form of $\mathrm{CaF}_{2}$ when main acid was injected, and 
$1 \mathrm{PV}$ of $9 \mathrm{wt} \%$ formic acid- $0.5 \mathrm{wt} \% \mathrm{HF}$ could cause less damage to the core compared with 3 PV of 9 wt $\%$ formic acid -1 wt $\% \mathrm{HF}$.

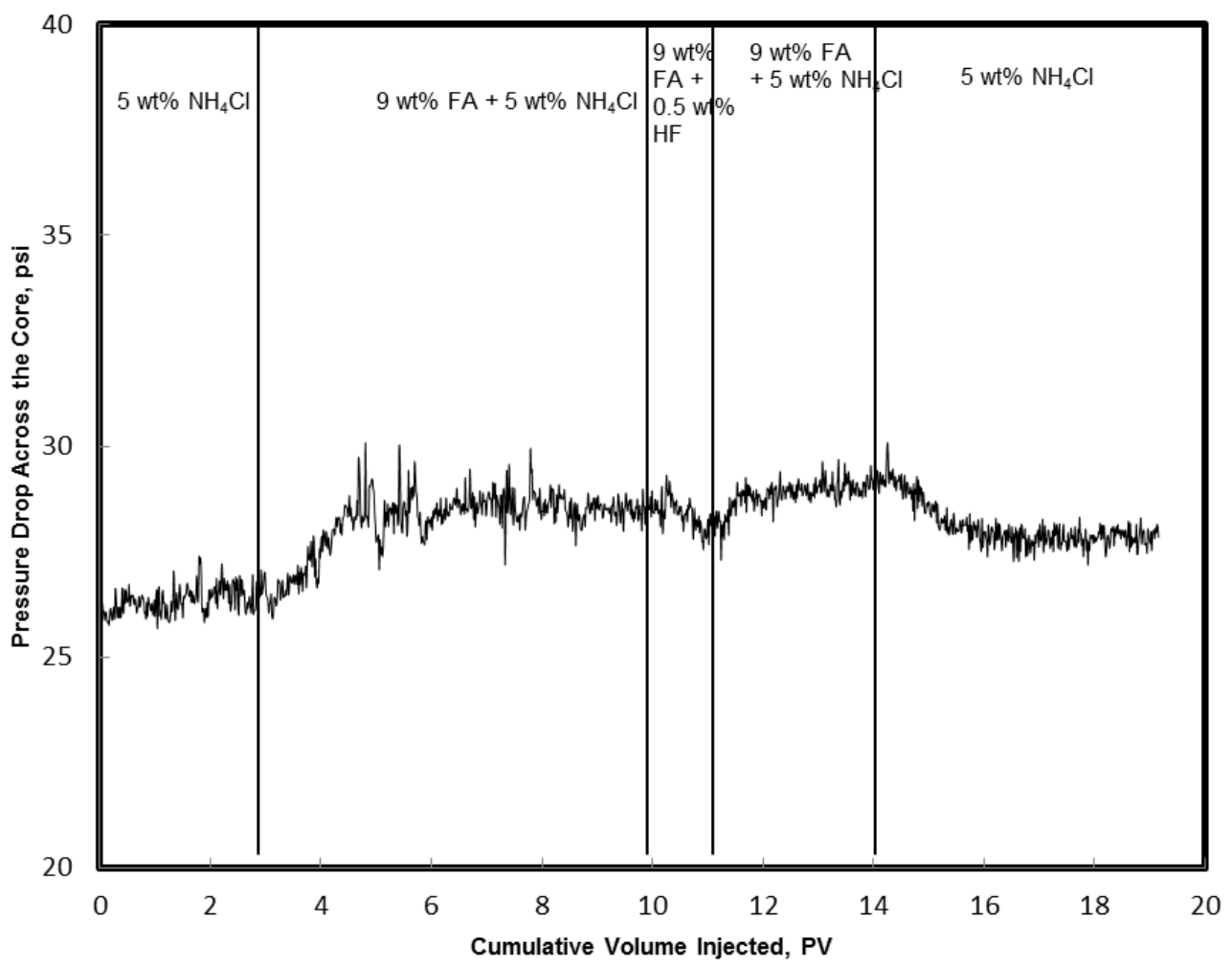

Fig. 21-Pressure drop across the core using $9 \mathrm{wt} \%$ formic acid with $5 \mathrm{wt} \%$ ammonium chloride as a preflush and $1 \mathrm{PV}$ of $9 \mathrm{wt} \%$ formic acid and $0.5 \mathrm{wt} \% \mathrm{HF}$ as the main flush at $75^{\circ} \mathrm{F}$ and $5 \mathrm{~cm}^{3} / \mathrm{min}$ on a Berea sandstone core. 


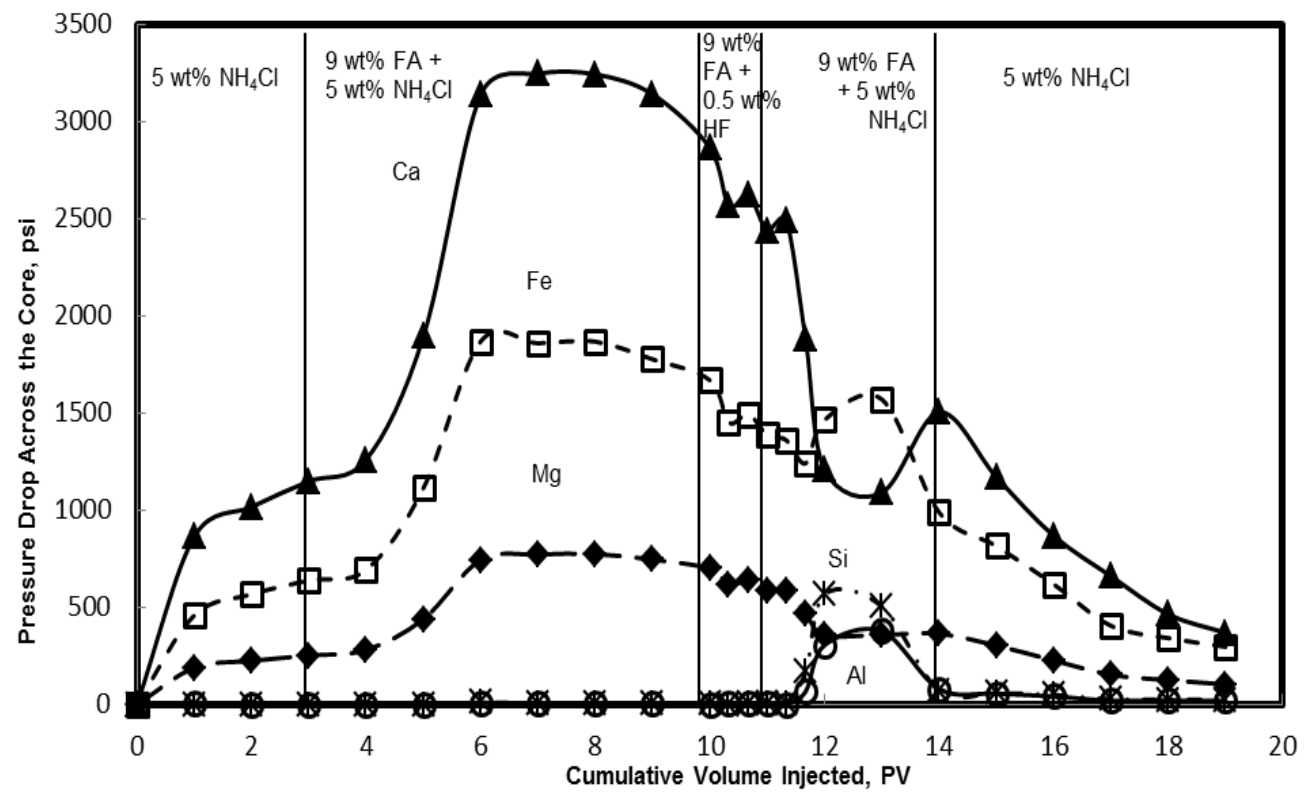

Fig. 22-Analysis of coreflood effluent samples for a Berea sandstone core treated by $9 \mathrm{wt} \%$ formic acid with $5 \mathrm{wt} \%$ ammonium chloride as a preflush and $1 \mathrm{PV}$ of $9 \mathrm{wt} \%$ formic acid with $0.5 \mathrm{wt} \% \mathrm{HF}$ as the main flush at room temperature and $5 \mathrm{~cm}^{3} / \mathrm{min}$.

\subsubsection{Core flood experiments on Berea sandstone cores under different temperatures}

Coreflood experiments F-6 and F-7 were conducted to investigate the effect of formic acid solution on sandstone cores and the influence of temperature during the acid preflush stage. In coreflood experiment F-6, $10 \mathrm{PV}$ of $9 \mathrm{wt} \%$ formic acid were injected into the Berea sandstone core at room temperature. The pressure drop across the core increased at first, and then decreased very slowly. Eventually, the permeability of the core decreased from 60 to 56 md (Fig. 23 ). 


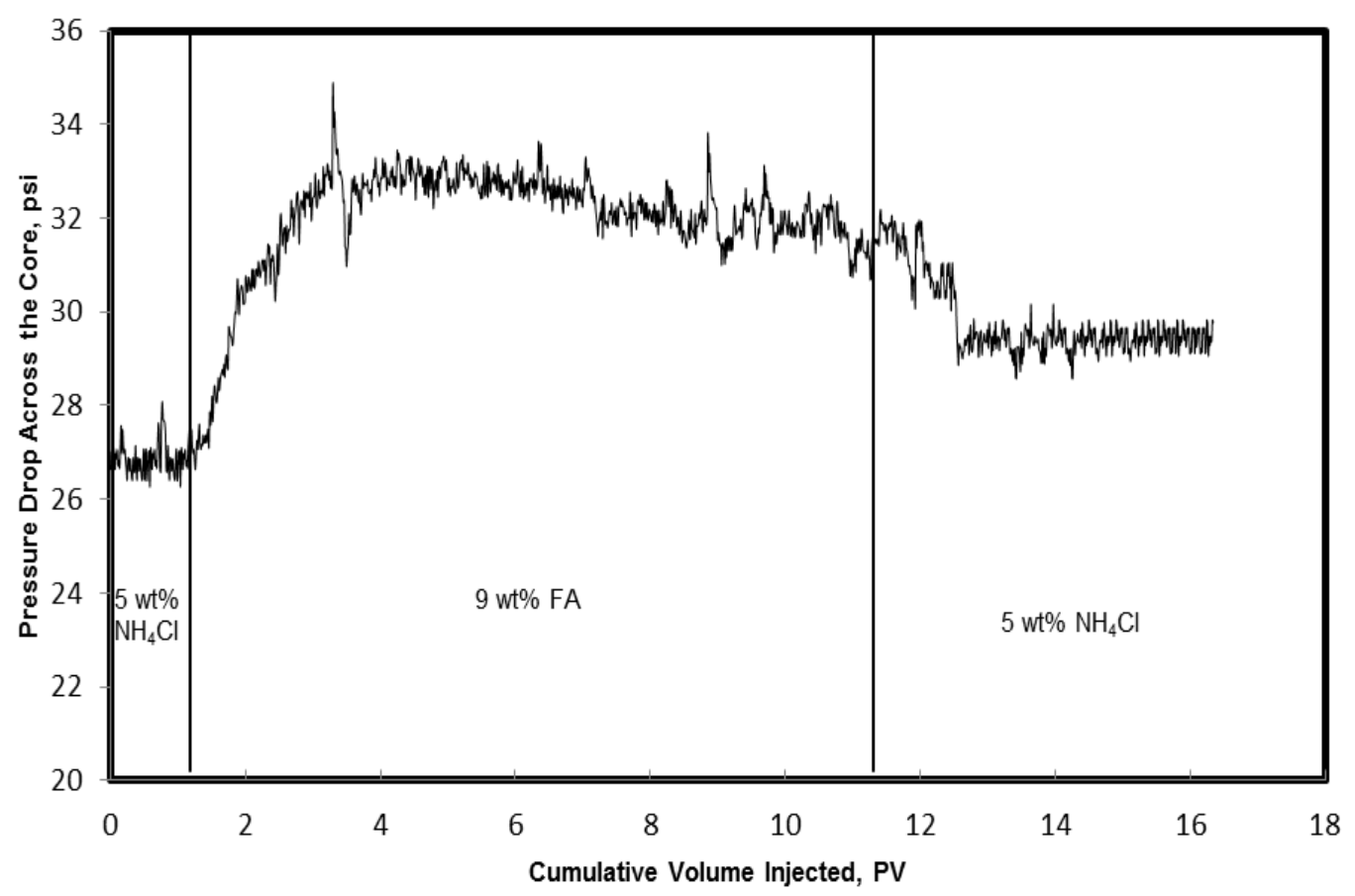

Fig. 23-Pressure drop across the core using $9 \mathrm{wt} \%$ formic acid at $75^{\circ} \mathrm{F}$ and $5 \mathrm{~cm}^{3} / \mathrm{min}$ on a Berea sandstone core.

The analysis of core flood experiment F-6 is shown in Fig. 6. At room temperature, large amounts of $\mathrm{Ca}, \mathrm{Fe}$, and $\mathrm{Mg}$ were removed by formic acid (Fig. 24). The concentrations of $\mathrm{Ca}, \mathrm{Fe}$, and $\mathrm{Mg}$ kept on increasing with the injection of acid, and reached their highest value after 6 PV of acid, and then started to drop very slowly. When $10 \mathrm{PV}$ of acid were injected, the concentrations of $\mathrm{Ca}, \mathrm{Fe}$, and $\mathrm{Mg}$ were 2,500, 1,400, and $600 \mathrm{mg} / \mathrm{l}$, respectively, which were still very high. Therefore, it can be concluded that a large volume of formic acid is needed to remove carbonates from Berea sandstone at room temperature. 


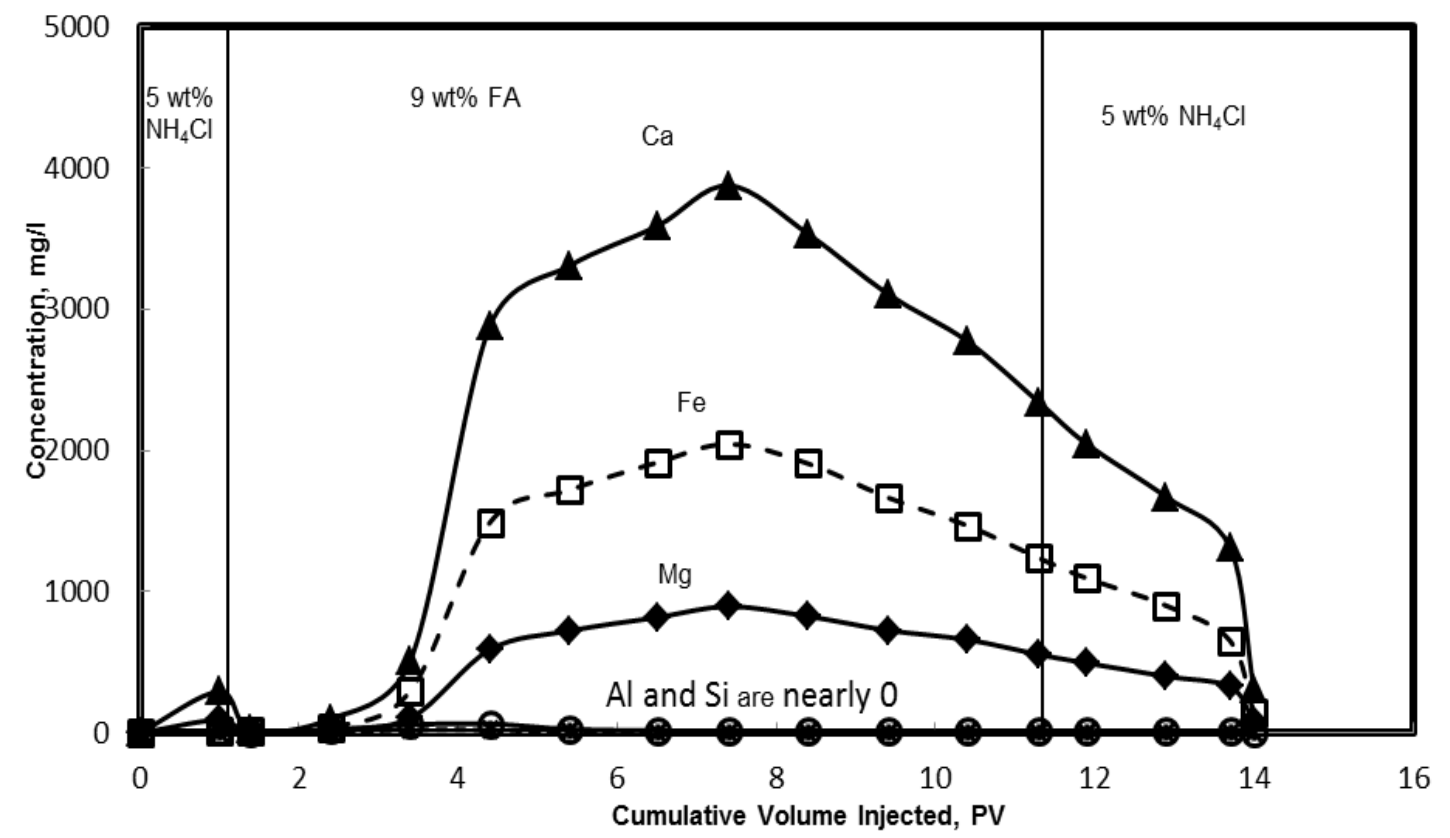

Fig. 24-Analysis of coreflood effluent samples of a Berea sandstone core treated by $9 \mathrm{wt} \%$ formic acid at $75^{\circ} \mathrm{F}$ and $5 \mathrm{~cm}^{3} / \mathrm{min}$.

In core flood experiment F-7, $10 \mathrm{PV}$ of $9 \mathrm{wt} \%$ formic acid was injected into the Berea sandstone core at $250^{\circ} \mathrm{F}$. The pressure drop across the core increased at the beginning of the injection of acid, and then decreased more rapidly than in core flood experiment F-6. The permeability increased from 56 to $58 \mathrm{md}$ (Fig. 25). 


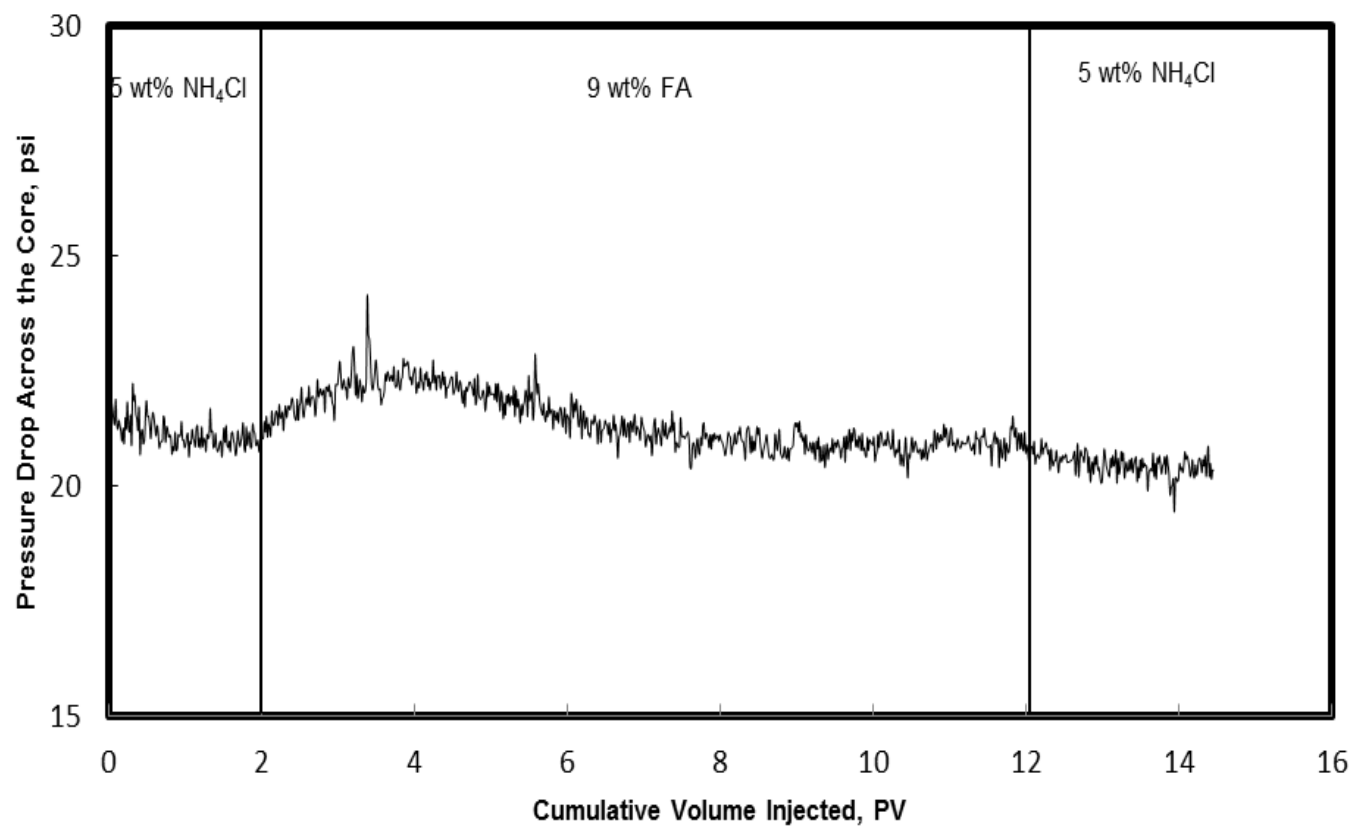

Fig. 25-Pressure drop across the core using $9 \mathrm{wt} \%$ formic acid at $250^{\circ} \mathrm{F}$ and $5 \mathrm{~cm}^{3} / \mathrm{min}$ on a Berea sandstone core.

In core flood experiment F-7, much higher concentrations of metal ions than at room temperature were observed. Also, it was noted that the concentrations of these ions started to drop rapidly only after 4 PV of acid preflush (Fig. 26). Much more cementing materials were removed than at room temperature. 


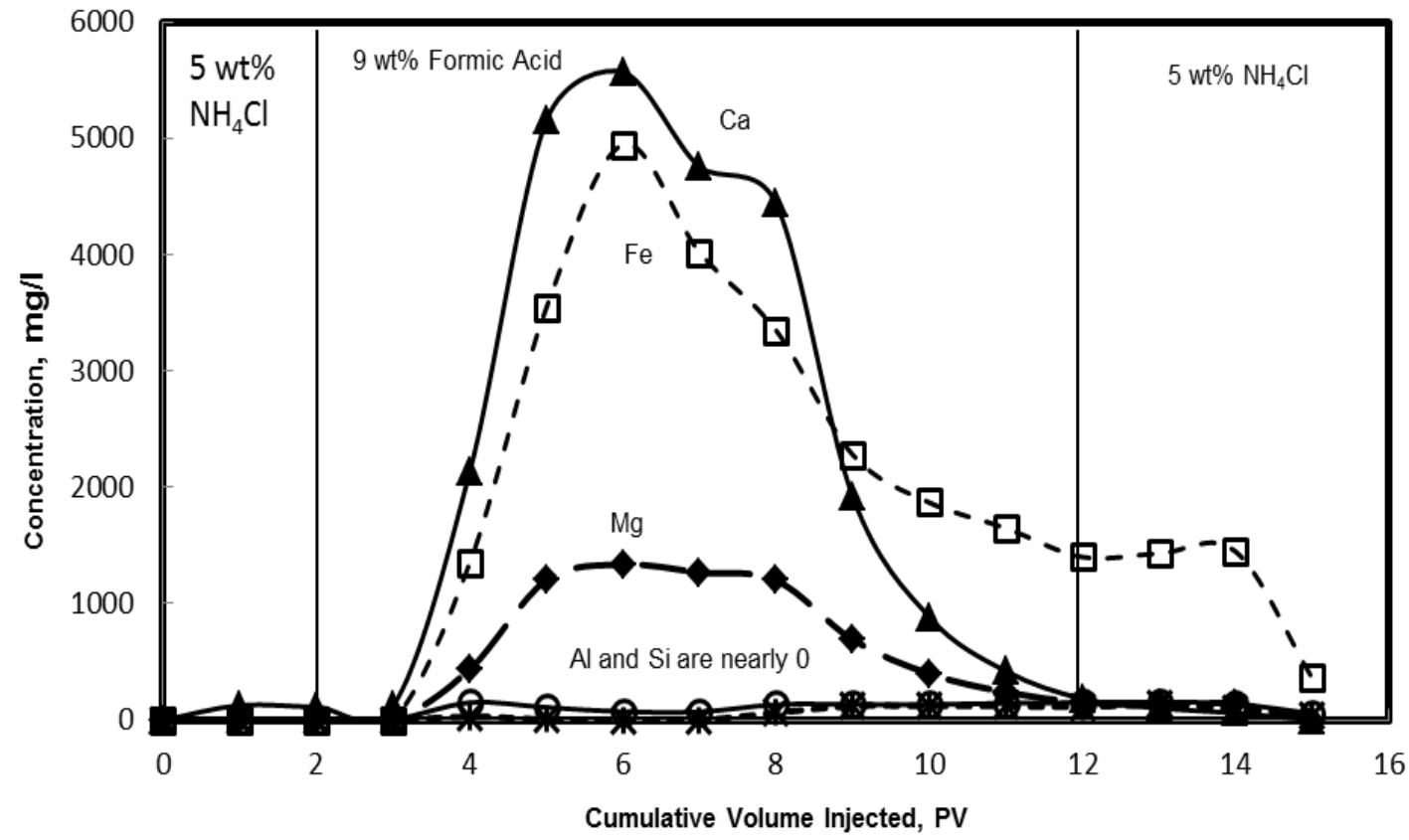

Fig. 26-Analysis of coreflood effluent samples of a Berea sandstone core treated by $9 \mathrm{wt} \%$ formic acid at $250^{\circ} \mathrm{F}$ and $5 \mathrm{~cm}^{3} / \mathrm{min}$.

Besides, Al and Si concentrations in core flood experiments F-6 and F-7 were both low during the whole process (Figs. 24 and 26). These indicate that formic acid is not effective in leaching $\mathrm{Al}$ or $\mathrm{Si}$ from clays present in Berea sandstone cores up to $250^{\circ} \mathrm{F}$, and the clay minerals inside the core were untouched during the preflush stage formic acid.

Core flood experiments F-8 to F-10 were conducted at 150,250 , and $350^{\circ} \mathrm{F}$, respectively, to compare with core flood experiment $\mathrm{F}-5$ which was under $75^{\circ} \mathrm{F}$. In coreflood experiment F-8, the permeability of the core increased from 56 to $58 \mathrm{md}$ after the acid treatment (Fig. 27). This permeability improvement is better than in core flood experiment F-5. 


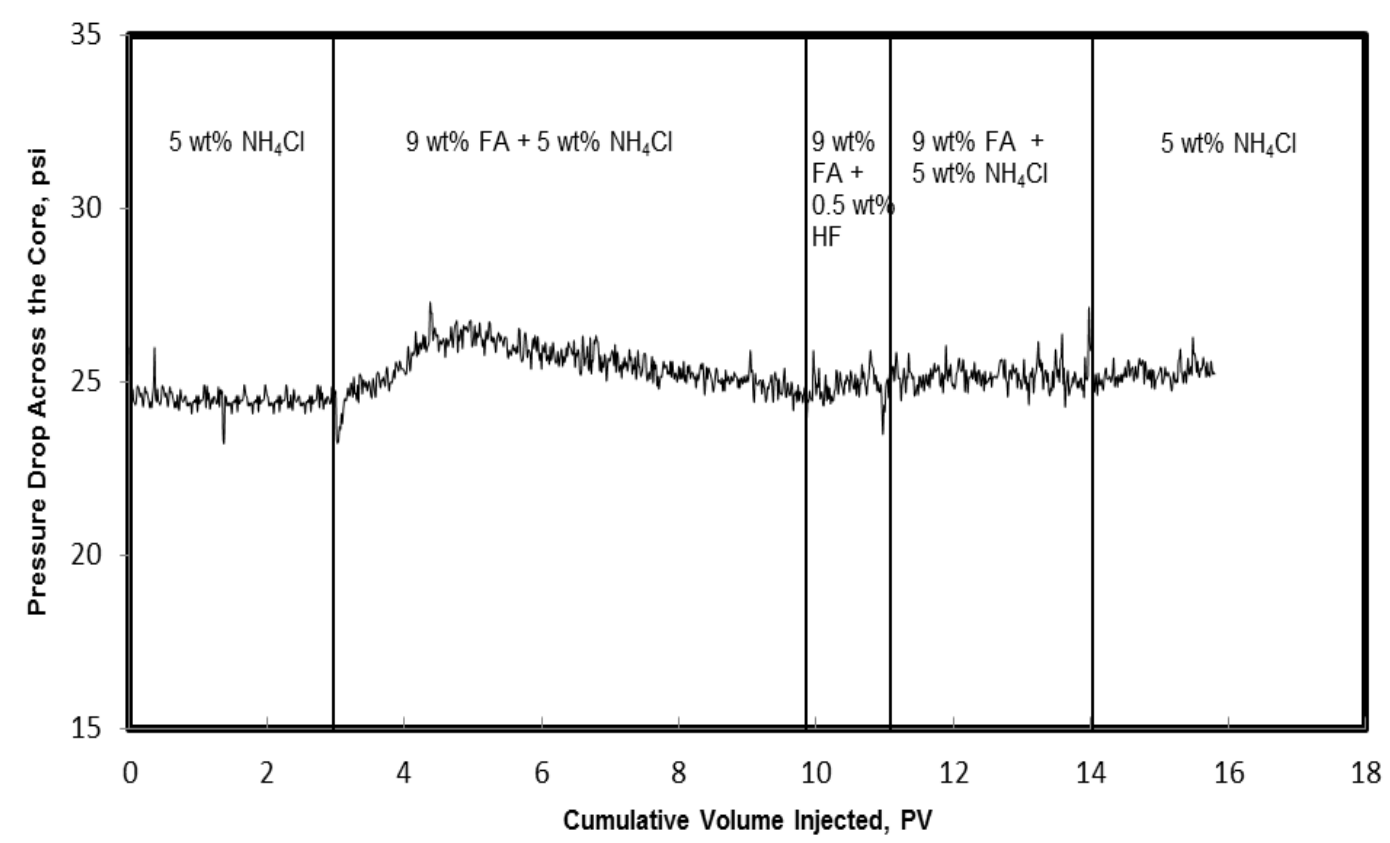

Fig. 27-Pressure drop across the core using $9 \mathrm{wt} \%$ formic acid with $5 \mathrm{wt} \%$ ammonium chloride as a preflush and $1 \mathrm{PV}$ of $9 \mathrm{wt} \%$ formic acid and $0.5 \mathrm{wt} \% \mathrm{HF}$ as the main flush at $150^{\circ} \mathrm{F}$ and $5 \mathrm{~cm}^{3} / \mathrm{min}$ on a Berea sandstone core.

In coreflood experiment F-8, the permeability of the core increased from 63 to 67 md (Fig. 28), and the permeability increased from 60 to $64 \mathrm{md}$ in coreflood experiment \#8 (Fig. 29). These improvements can be attributed to small amount of fluorides and effective removal of carbonates during preflush, which both leave less possibility for $\mathrm{CaF}_{2}$ to precipitate. The decreased density can further prove these after acid treatment (Fig. 30). 


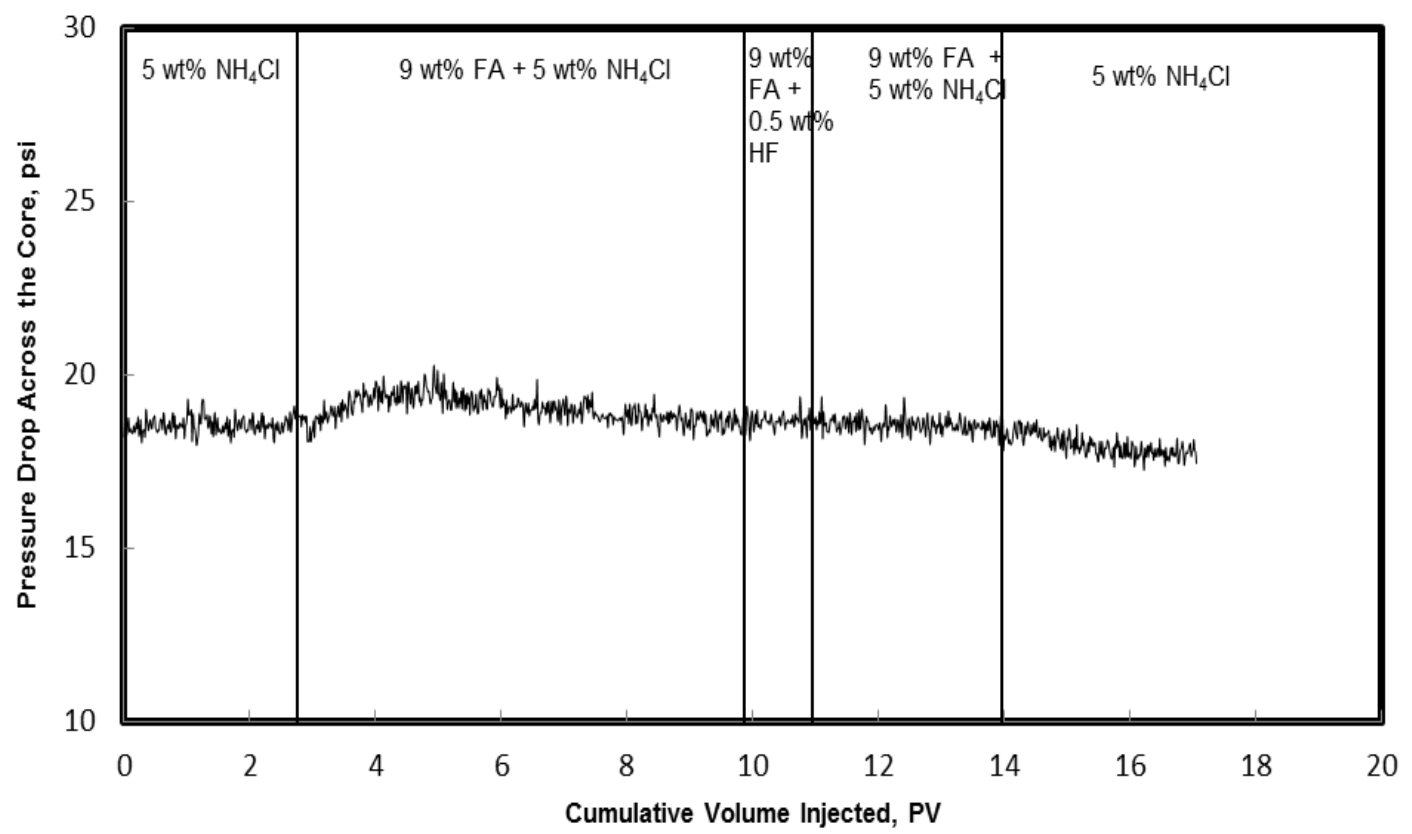

Fig. 28-Pressure drop across the core using $9 \mathrm{wt} \%$ formic acid with $5 \mathrm{wt} \%$ ammonium chloride as a preflush and $1 \mathrm{PV}$ of $9 \mathrm{wt} \%$ formic acid and $0.5 \mathrm{wt} \% \mathrm{HF}$ as the main flush at $250^{\circ} \mathrm{F}$ and $5 \mathrm{~cm}^{3} / \mathrm{min}$ on a Berea sandstone core.

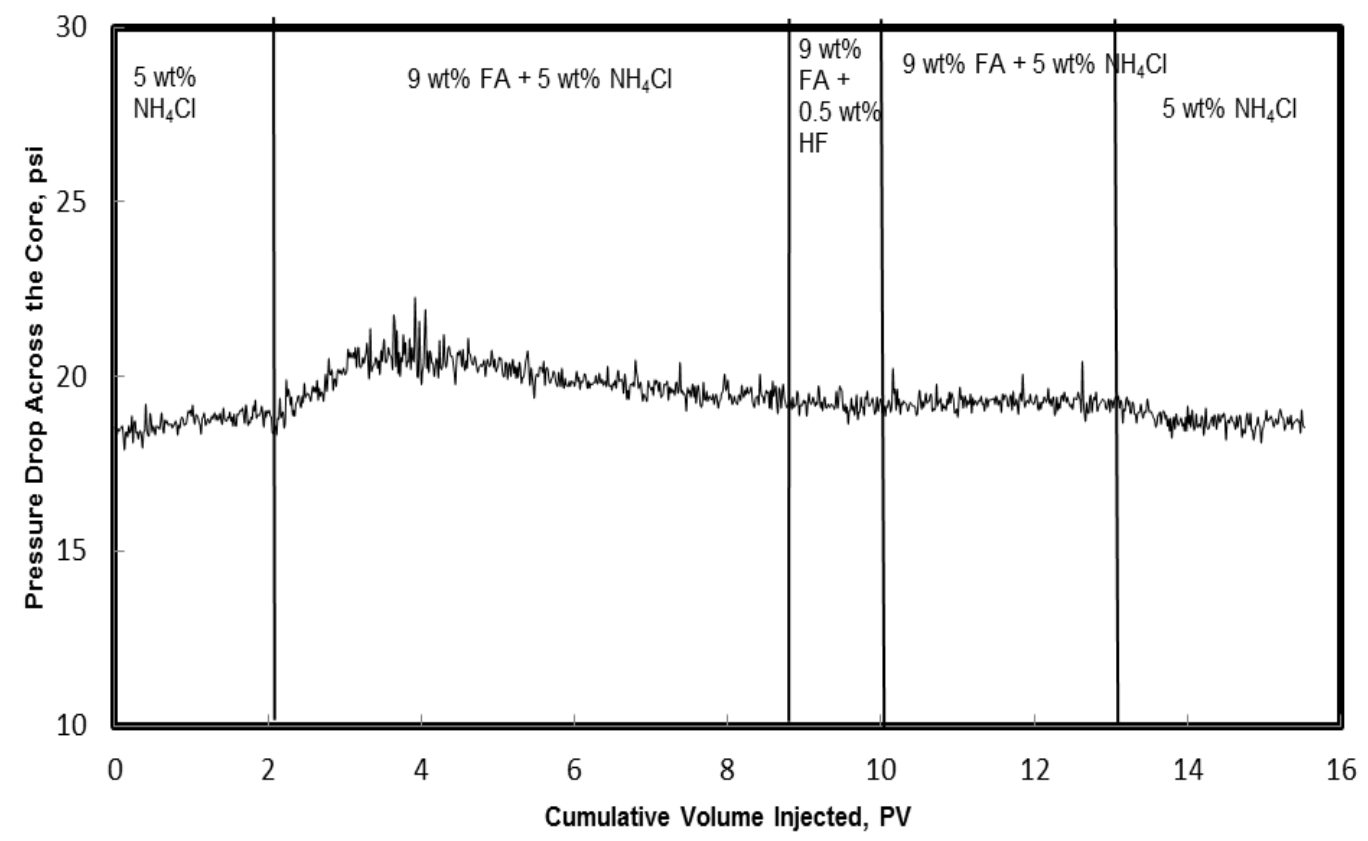

Fig. 29-Pressure drop across the core using $9 \mathrm{wt} \%$ formic acid with $5 \mathrm{wt} \%$ ammonium chloride as a preflush and $1 \mathrm{PV}$ of $9 \mathrm{wt} \%$ formic acid and $0.5 \mathrm{wt} \% \mathrm{HF}$ as the main flush at $350^{\circ} \mathrm{F}$ and $5 \mathrm{~cm}^{3} / \mathrm{min}$ on a Berea sandstone core. 


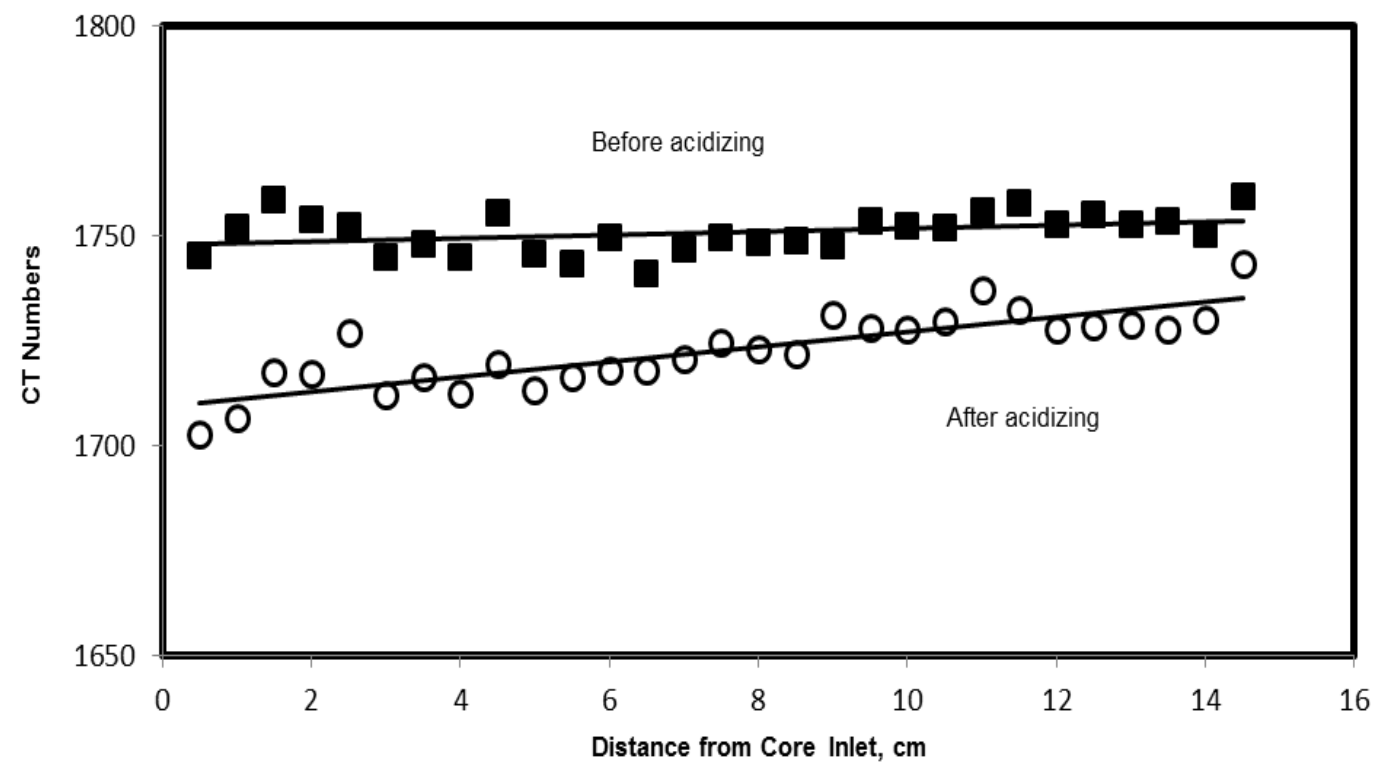

Fig. 30-CT number across the Berea sandstone core before and after the acid treatment using $9 \mathrm{wt} \%$ formic acid with $5 \mathrm{wt} \%$ ammonium chloride as a preflush and $1 \mathrm{PV}$ of $9 \mathrm{wt} \%$ formic acid with $0.5 \mathrm{wt} \%$ $\mathrm{HF}$ as the main flush at $150^{\circ} \mathrm{F}$ and $5 \mathrm{~cm}^{3} / \mathrm{min}$.

Overall, better permeability improvements were achieved at higher temperatures, when $1 \mathrm{PV}$ of $9 \mathrm{wt} \%$ formic acid and $0.5 \mathrm{wt} \% \mathrm{HF}$ was used in the main stage.

The ratio of $\mathrm{Si} / \mathrm{Al}$ was also investigated. At room temperature, the ratio of $\mathrm{Si} / \mathrm{Al}$ was nearly 2:1 (Fig. 22). However, Si/Al ratio decreased to $1: 1$ at $150^{\circ} \mathrm{F}$ (Fig. 31), and 1:2 at $250^{\circ} \mathrm{F}$ (Fig. 32). Si/Al ratio further dropped to $1: 3$ at $350^{\circ} \mathrm{F}$ (Fig. 33). 


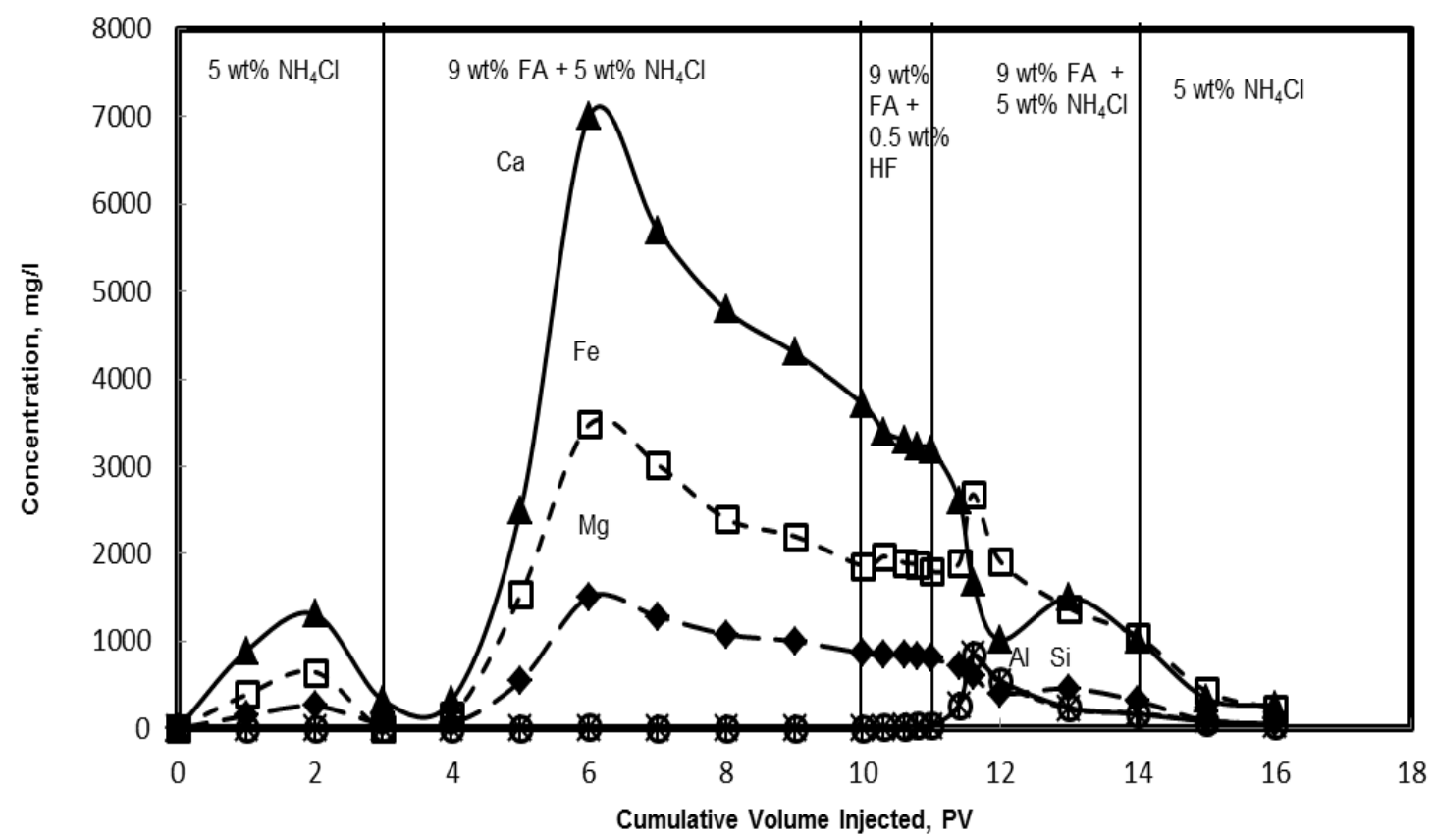

Fig. 31-Analysis of coreflood effluent samples for a Berea sandstone core treated by $9 \mathrm{wt} \%$ formic acid with $5 \mathrm{wt} \%$ ammonium chloride as a preflush and $1 \mathrm{PV}$ of $9 \mathrm{wt} \%$ formic acid with $0.5 \mathrm{wt} \% \mathrm{HF}$ as the main flush at $150^{\circ} \mathrm{F}$ and $5 \mathrm{~cm}^{3} / \mathrm{min}$.

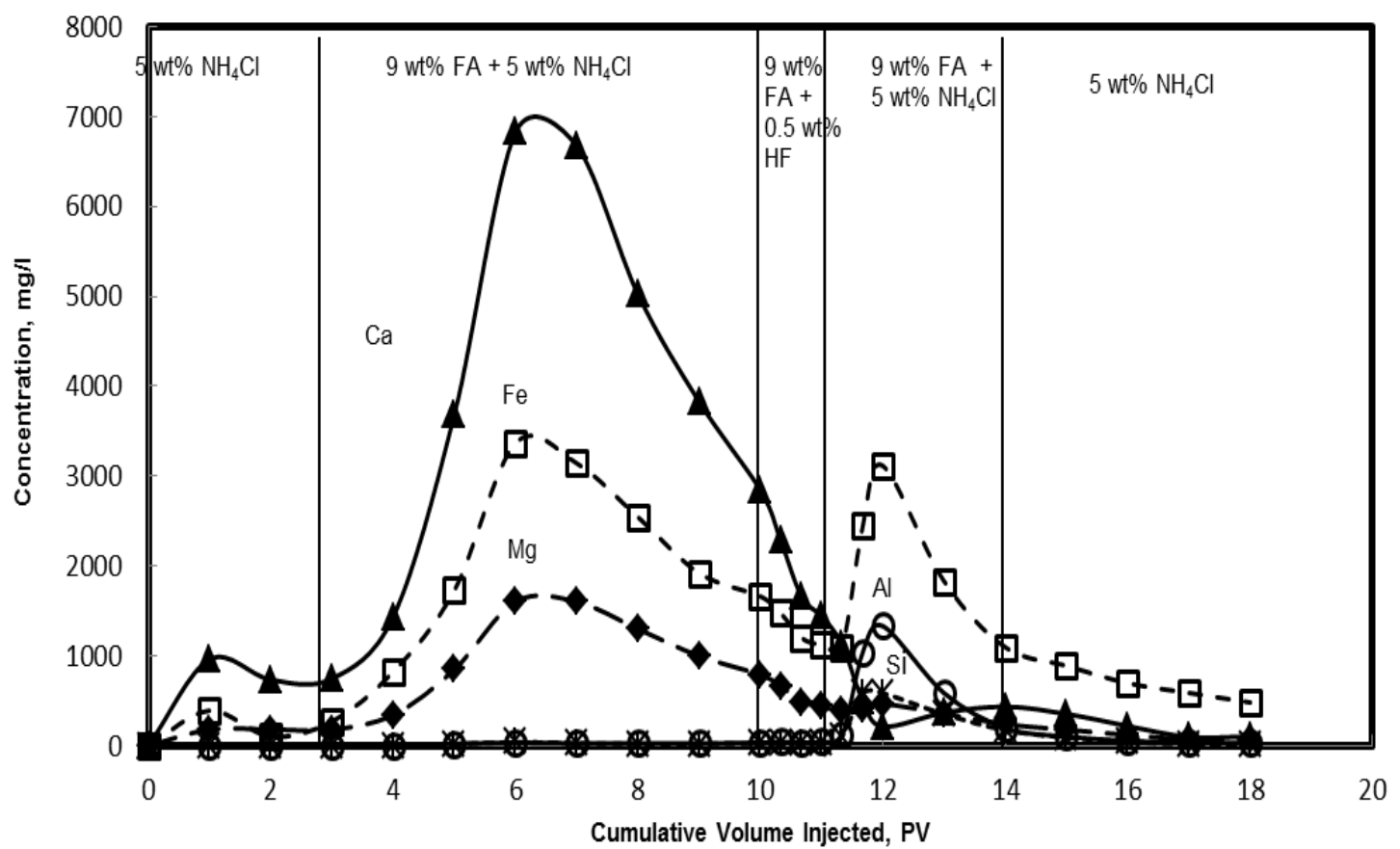

Fig. 32-Analysis of coreflood effluent samples for a Berea sandstone core treated by $9 \mathrm{wt} \%$ formic acid with $5 \mathrm{wt} \%$ ammonium chloride as a preflush and $1 \mathrm{PV}$ of $9 \mathrm{wt} \%$ formic acid with $0.5 \mathrm{wt} \% \mathrm{HF}$ as the main flush at $250^{\circ} \mathrm{F}$ and $5 \mathrm{~cm}^{3} / \mathrm{min}$. 


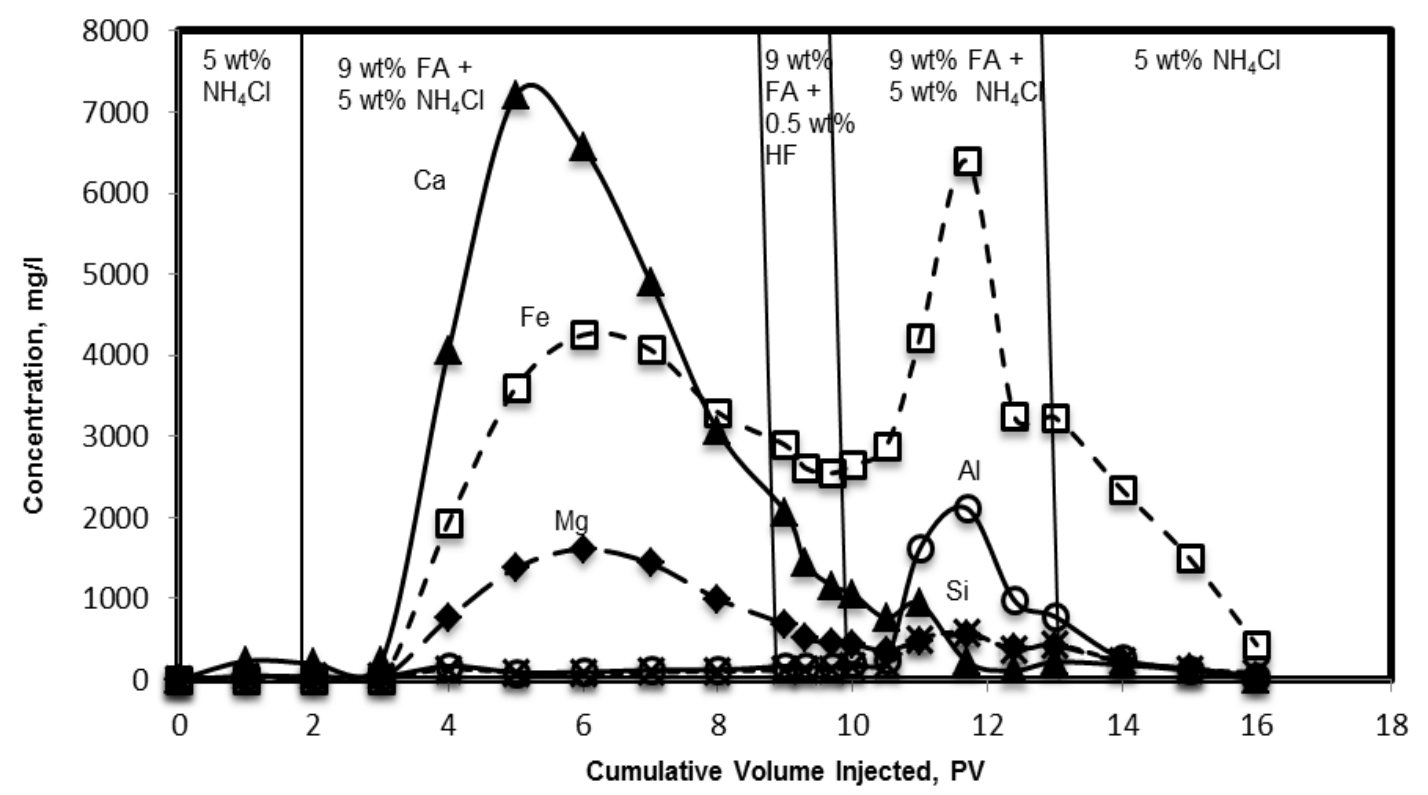

Fig. 33-Analysis of coreflood effluent samples for a Berea sandstone core treated by $9 \mathrm{wt} \%$ formic acid with $5 \mathrm{wt} \%$ ammonium chloride as a preflush and $1 \mathrm{PV}$ of $9 \mathrm{wt} \%$ formic acid with $0.5 \mathrm{wt} \% \mathrm{HF}$ as the main flush at $350^{\circ} \mathrm{F}$ and $5 \mathrm{~cm}^{3} / \mathrm{min}$.

This change can be explained by the secondary reaction of aluminosilicates with HF. When temperature increased, the extent of secondary reaction increased as well. In the secondary reaction, fluosilicic acid was consumed by aluminosilicates to generate more aluminum fluoride species, while Si transferred from fluosilicic acid to silica gel. Thus, the concentration of $\mathrm{Al}$ in spent acid solution increased, while the concentration of $\mathrm{Si}$ decreased. As a result, the ratio of $\mathrm{Si} / \mathrm{Al}$ decreased with the increase of temperature. 


\subsection{Acetic-HF Acids}

\subsubsection{Clay solubility in acetic-HF acids}

The ion concentrations in $13 \mathrm{wt} \%$ acetic-HF acids after reaction with clay minerals for 0.5 hour under room temperature are shown in this part. HF concentration varied from $0.5 \mathrm{wt} \%$ to $6 \mathrm{wt} \%$. After the reactions with kaolinite (Fig.34), only Si and $\mathrm{Al}$ were detected in the spent acid solutions, since kaolinite is composed of $\mathrm{Al}, \mathrm{Si}$, and $\mathrm{O}$ only. With the increase of HF concentration, more Si and Al were released at the same time. The values in each experiment are very close to the results of kaolinite solubility test in formic-HF acids (Fig. 5).

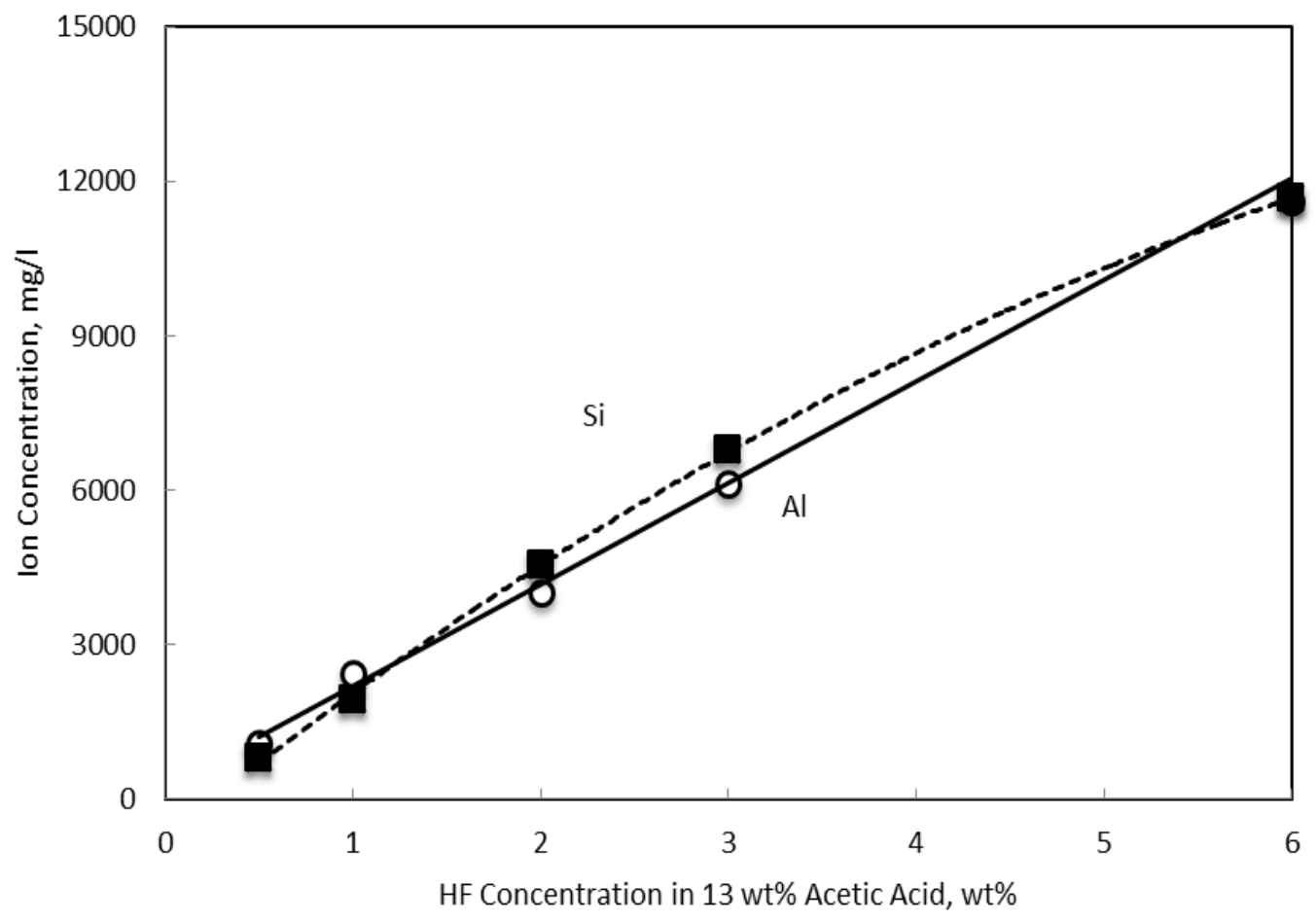

Fig. 34-Ion concentrations in $13 \mathrm{wt} \%$ acetic-HF acid solutions after reactions with kaolinite at room temperature. 
After the reactions of acetic-HF acids with chlorite and illite (Figs. 35 and 36), $\mathrm{Si}$ and $\mathrm{Fe}$ were the major metal ions that were found in the spent acid solutions also. No Al was detected in all the experiments. This observation is also the same as what we found in the chlorite and illite solubility tests in formic-HF acids.

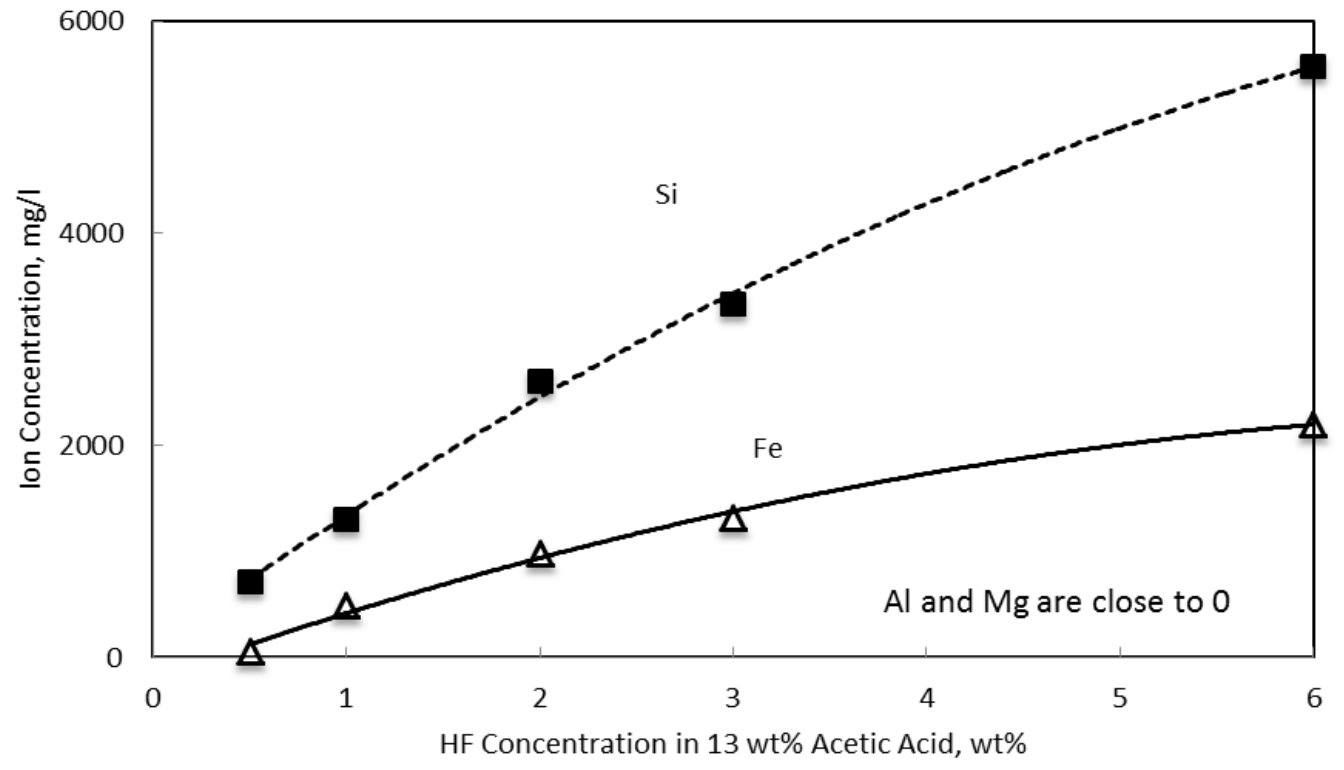

Fig. 35-Ion concentrations in $13 \mathrm{wt} \%$ acetic-HF acid solutions after reactions with chlorite at room temperature. 


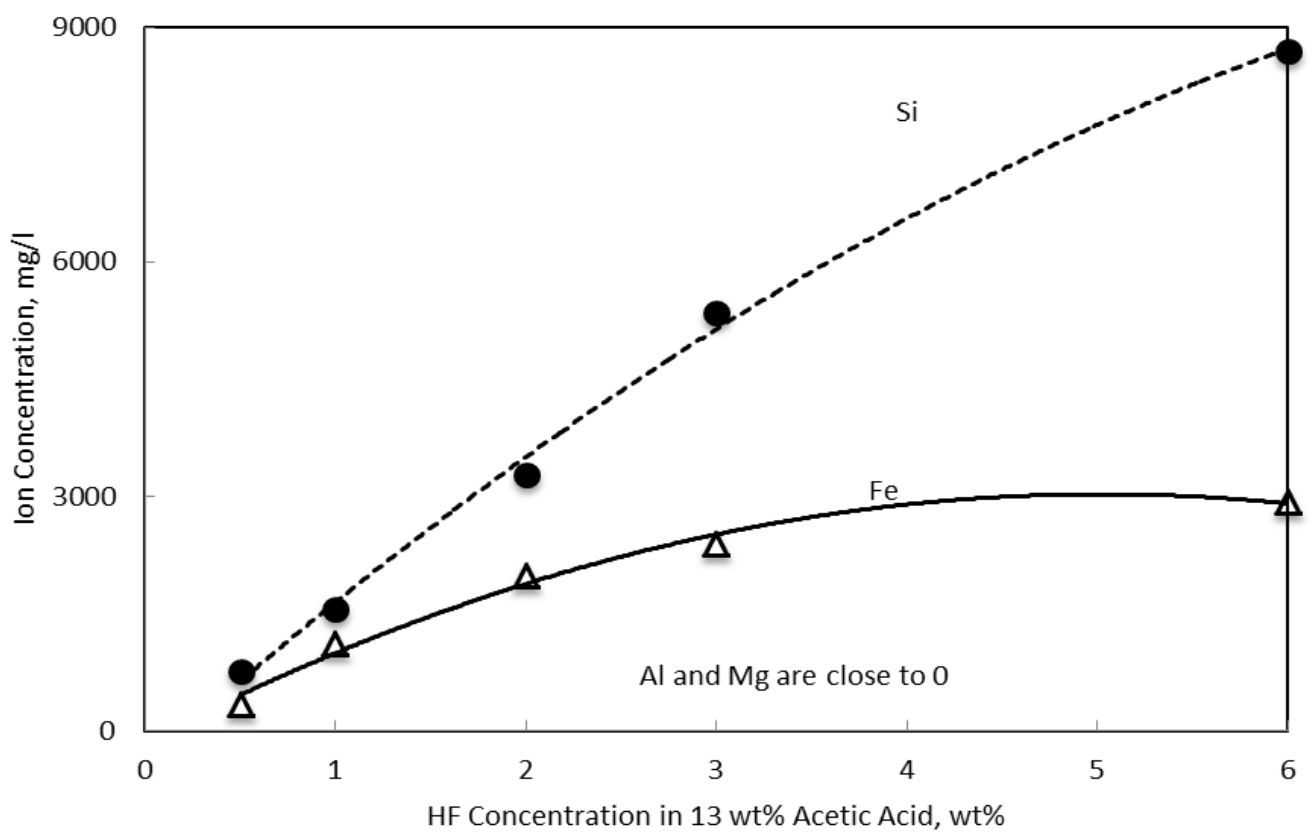

Fig. 36-Ion concentrations in $13 \mathrm{wt} \%$ acetic-HF acid solutions after reactions with illite at room temperature.

${ }^{19} \mathrm{~F}$ NMR spectra of $13 \mathrm{wt} \%$ acetic acid $-0.5 \mathrm{wt} \% \mathrm{HF}$ after reaction with kaolinite, illite, and chlorite are shown in Figs. 37 through $39 . \mathrm{CFCl}_{3}$ was used as a reference also. In the ${ }^{19} \mathrm{~F}$ NMR spectrum of $13 \mathrm{wt} \%$ acetic acid $-0.5 \mathrm{wt} \% \mathrm{HF}$ after reaction with kaolinite (Fig. 37), there are two groups of signals in the spectrum, one is at $-129 \mathrm{ppm}$, and the other one is at $-155 \mathrm{ppm}$. As described before, these chemical shifts can be converted to nearly -52.45 and $-78.45 \mathrm{ppm}$, respectively, if we use $\mathrm{CF}_{3} \mathrm{COOH}$ as a reference. These values are very close to the values reported by Shuchart and Buster (1995). Also, the peaks' shape and positions are very similar to what we found in the kaolinite solubility test in formic-HF acids (Fig. 6). There is no peak in that region of HF. Therefore it can be concluded that when the weight ratio between kaolinite and 13 $\mathrm{wt} \%$ acetic- $0.5 \mathrm{wt} \% \mathrm{HF}$ acids is $1: 5$, HF was completely consumed after 0.5 hour at 
room temperature, and both aluminum fluoride and silicon fluoride species were produced.

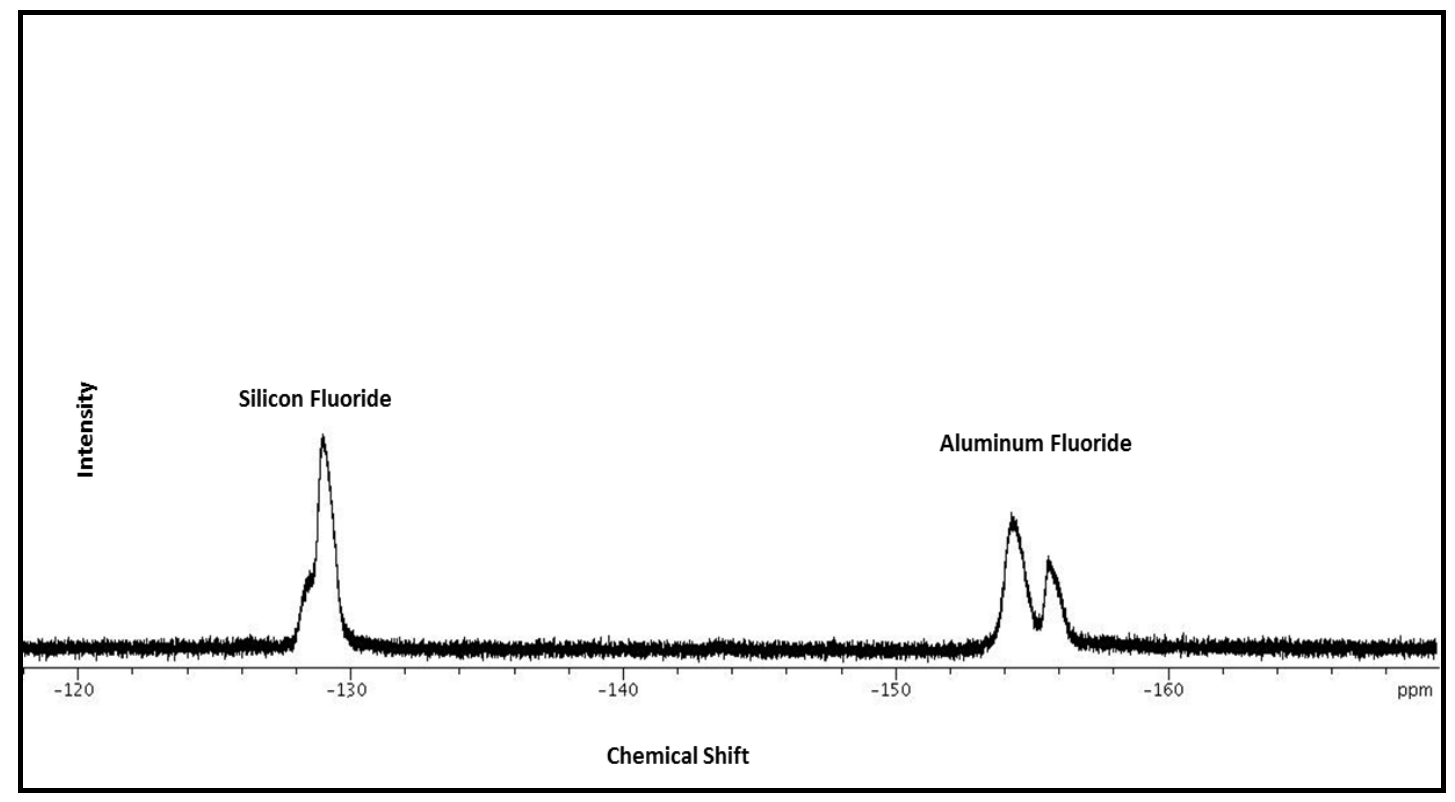

Fig. 37- ${ }^{19} \mathrm{~F}$ NMR spectrum of $13 \mathrm{wt} \%$ acetic acid- $0.5 \mathrm{wt} \% \mathrm{HF}$ after reaction with kaolinite for 0.5 hour at $75^{\circ} \mathrm{F}$.

In the ${ }^{19} \mathrm{~F}$ NMR spectra of $13 \mathrm{wt} \%$ acetic acid $-0.5 \mathrm{wt} \% \mathrm{HF}$ after reaction with chlorite and illite (Figs. 38 and 39), the only peaks are noted in the region of silicon fluorides. These indicate that all of the fluoride ions in spent acids are coordinated with silicon. Also, no HF peak is observed, which means that HF was completely consumed. It can be concluded that HF was completely consumed, and silicon fluoride species were the major products. 


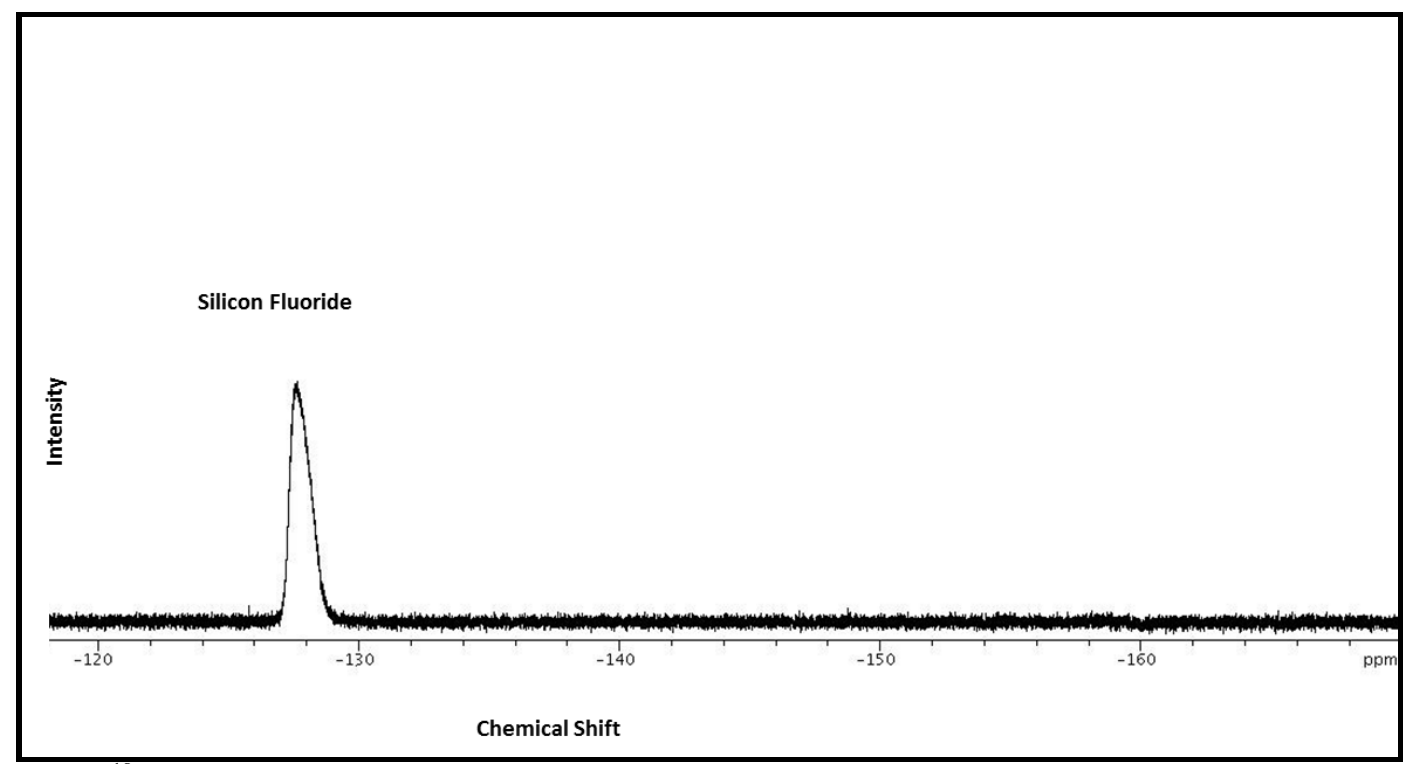

Fig. 38- ${ }^{19} \mathrm{~F}$ NMR spectrum of $13 \mathrm{wt} \%$ acetic acid- $0.5 \mathrm{wt} \% \mathrm{HF}$ after reaction with chlorite for 0.5 hour at $75^{\circ} \mathrm{F}$.

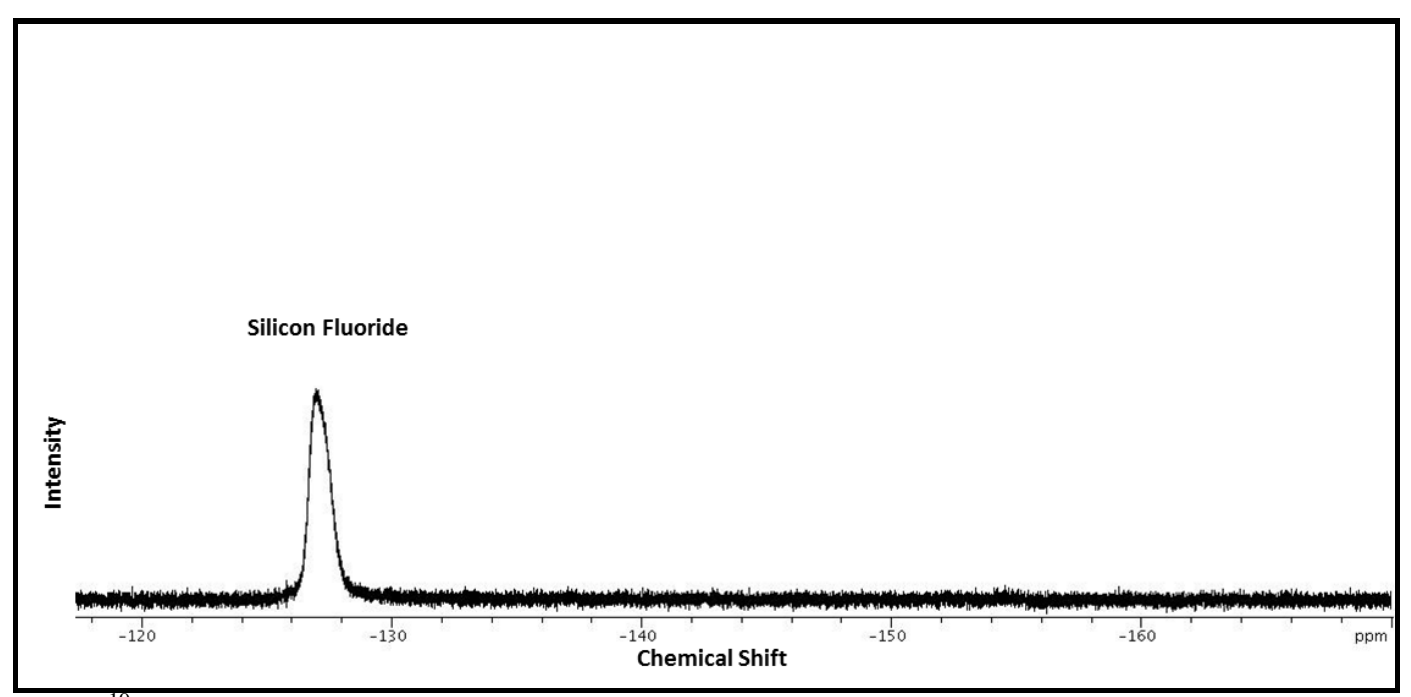

Fig. 39- ${ }^{19} \mathrm{~F}$ NMR spectrum of $13 \mathrm{wt} \%$ acetic acid- $0.5 \mathrm{wt} \% \mathrm{HF}$ after reaction with illite for 0.5 hour at $75^{\circ} \mathrm{F}$.

In all, ${ }^{19} \mathrm{~F}$ NMR spectra of $13 \mathrm{wt} \%$ acetic- $0.5 \mathrm{wt} \% \mathrm{HF}$ acids after reaction with clays are very similar to those of $9 \mathrm{wt} \%$ formic $-0.5 \mathrm{wt} \% \mathrm{HF}$ acids. This indicates that 13 
wt $\%$ acetic-HF acids and $9 \mathrm{wt} \%$ formic-HF acids have almost the same performance in the reactions with clays.

It was reported that $\mathrm{AlF}_{3}$ was more likely to precipitate when a higher concentration of HF was used, and it also more likely formed in acetic-HF acids than in formic-HF acids (Shuchart et al. 1996). To investigate whether $\mathrm{AlF}_{3}$ precipitated under our experimental conditions, SEM and EDS analysis were utilized to analyze all the clay particles after treated by $13 \mathrm{wt} \%$ acetic- $6 \mathrm{wt} \% \mathrm{HF}$ acids. The results are shown in Figs. 40 through 42. The element analysis of all the samples did not indicate the existence of $\mathrm{AlF}_{3}$ as reaction products, since no $\mathrm{F}$ peak was found in these spectra at all.

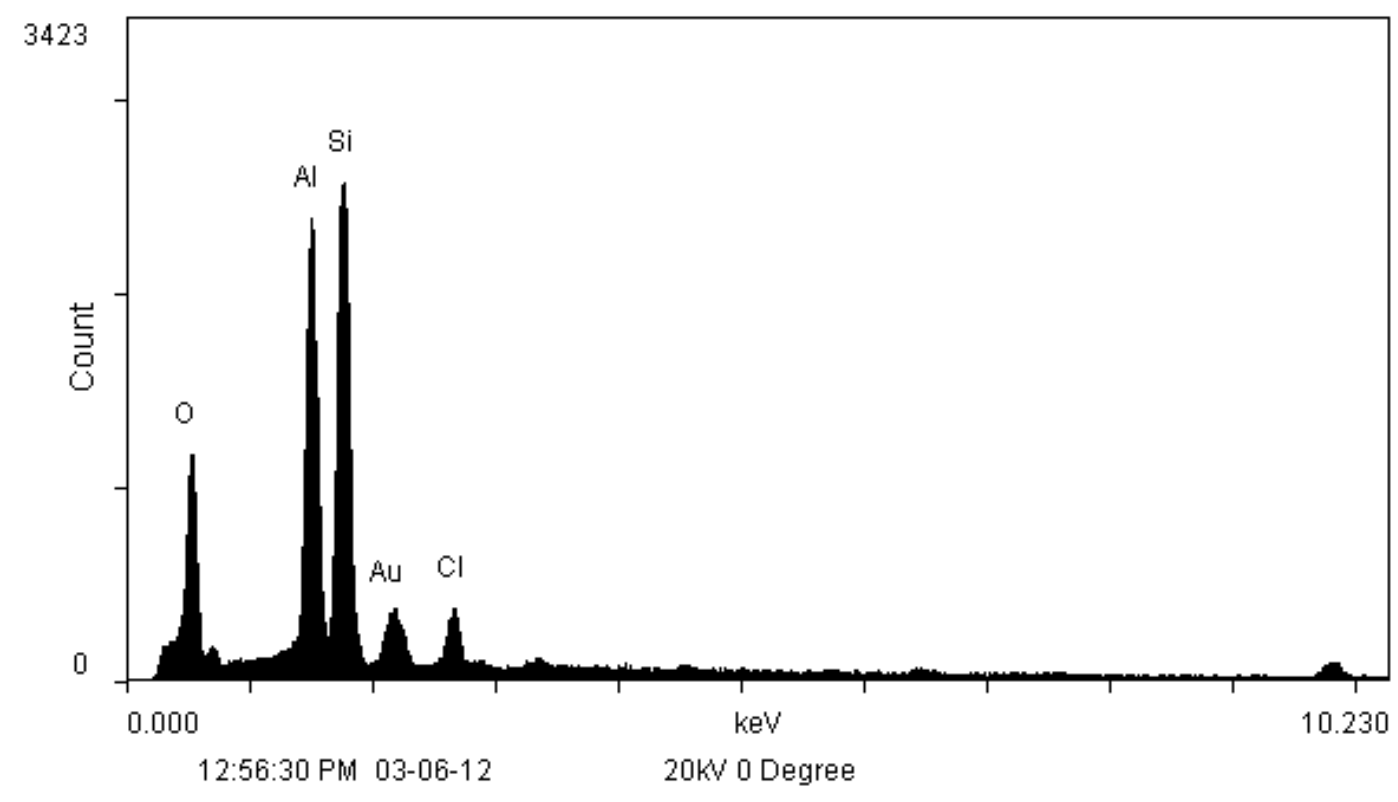

Fig. 40 - Element analysis of kaolinite after treated with $13 \mathrm{wt} \%$ acetic acid- $6 \mathrm{wt} \% \mathrm{HF}$ at room temperature. 


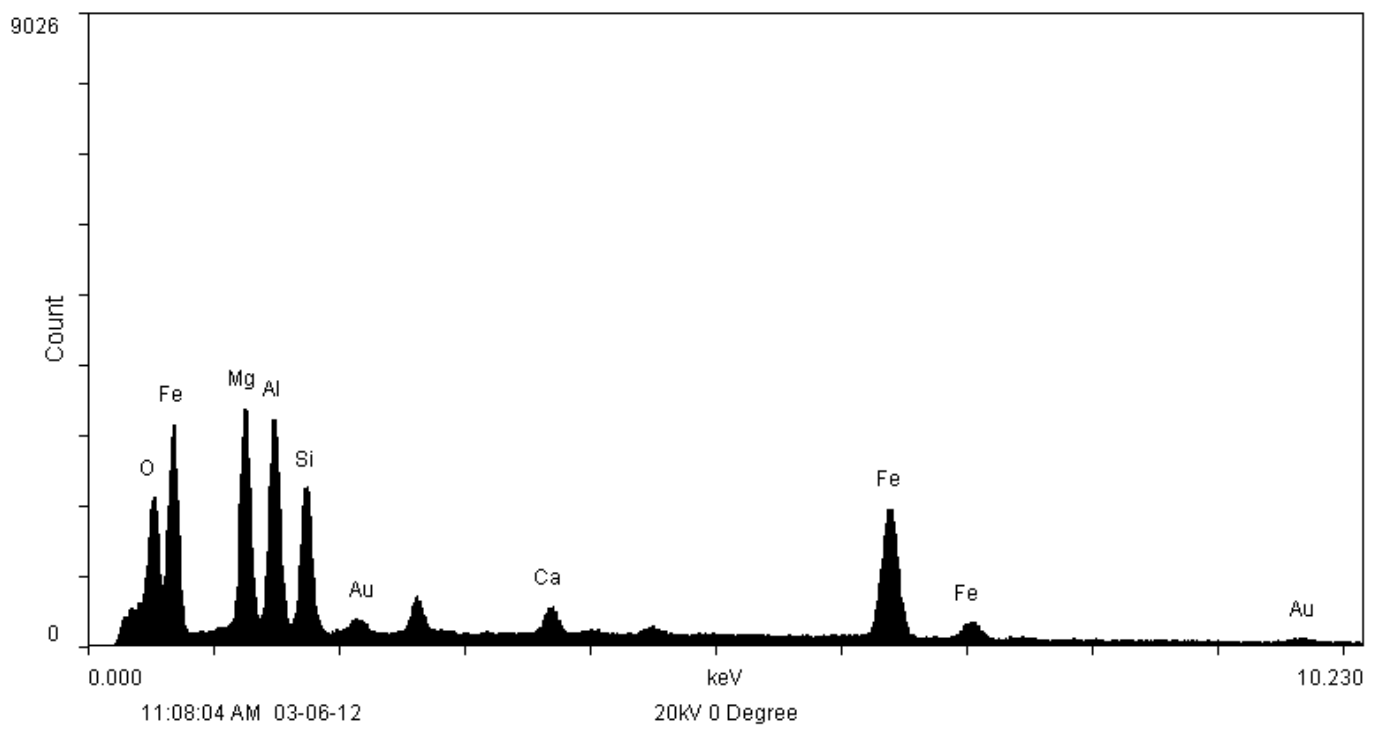

Fig. 41- Element analysis of chlorite after treated with $13 \mathrm{wt} \%$ acetic acid-6 wt $\% \mathrm{HF}$ at room temperature.

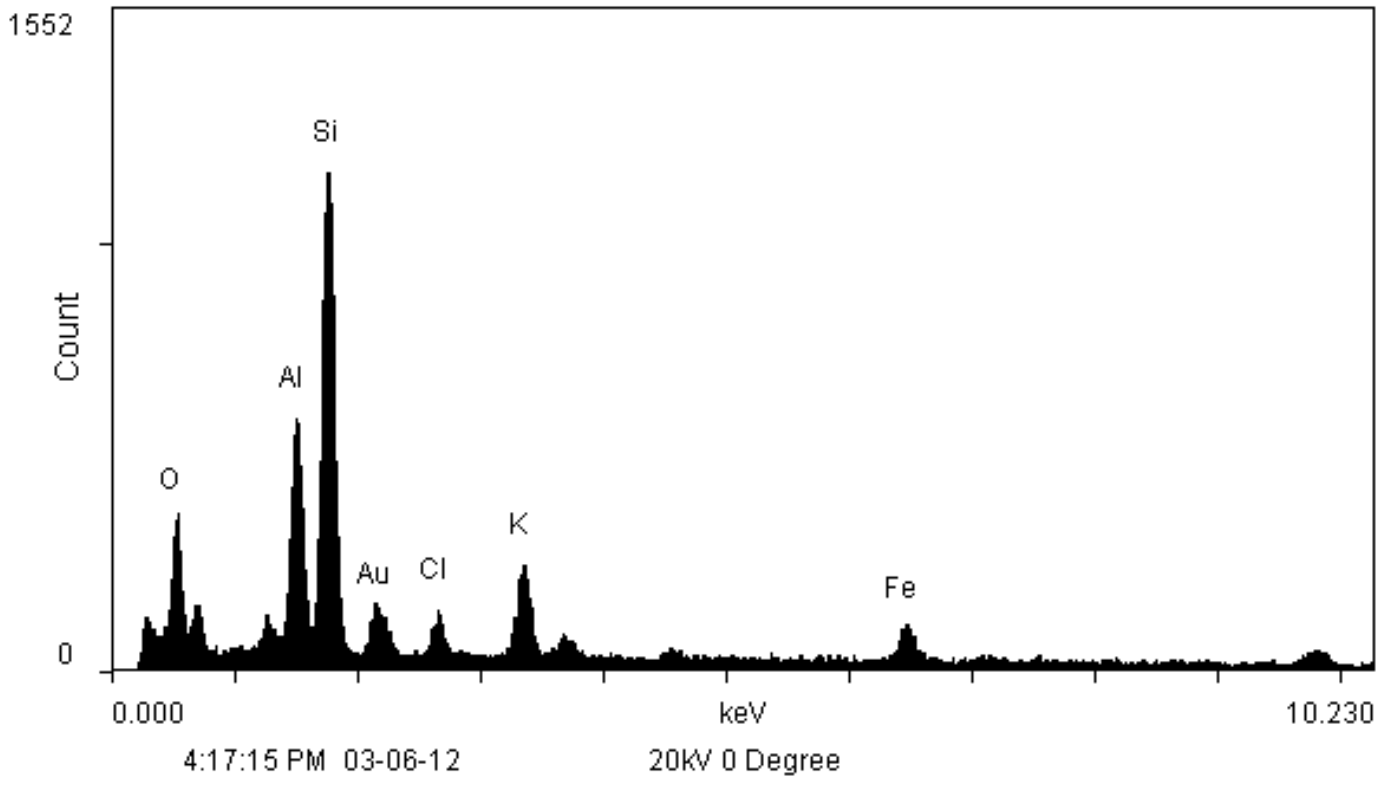

Fig. 42- Element analysis of illite after treated with $13 \mathrm{wt} \%$ acetic acid-6 wt $\% \mathrm{HF}$ at room temperature. 


\subsubsection{Core flood experiments on Berea and Bandera sandstone cores using acetic-HF acids}

Core flood experiments were also conducted using acetic-HF acids on both Berea and Bandera sandstone cores, to evaluate the performance of acetic-HF acids in sandstone acidizing. Effluent samples were collected during both core flood experiments. Concentrations of metal ions were then analyzed, and are shown in Figs. 43 and 44.

During the core flood experiment on Berea sandstone (Fig. 43), the concentrations of $\mathrm{Si}$ and $\mathrm{Al}$ were very low during the acid preflush stage. This indicated that acetic acid, just like formic acid, also does not react with clay minerals. So no clay minerals were touched during preflush stage using acetic acid. Since the start of the injection of $13 \mathrm{wt} \%$ acetic- $1 \mathrm{wt} \% \mathrm{HF}$ acids, both $\mathrm{Si}$ and $\mathrm{Al}$ concentrations increased quickly. Si concentration reached as high as $1,800 \mathrm{mg} / \mathrm{l}$, while $\mathrm{Al}$ concentration also rose up to $1,300 \mathrm{mg} / \mathrm{l}$. This indicated that the clay minerals inside the Berea sandstone core reacted with $\mathrm{HF}$ in the main flush stage.

The profile of the ion concentrations during the whole core flood experiment is almost the same as in the core flood experiment using formic-HF acids (Fig. 13). 


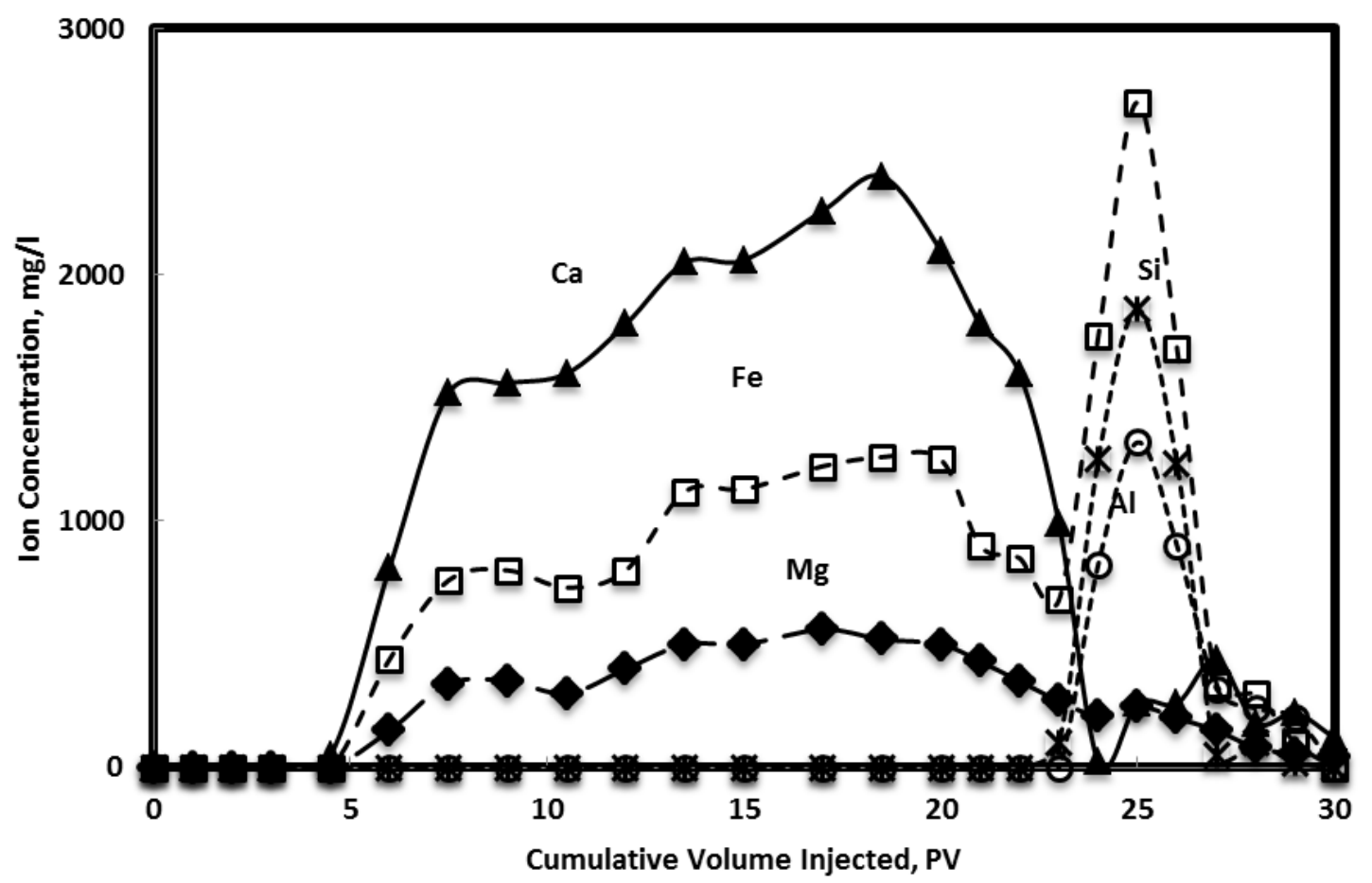

Fig. 43-Analysis of core flood effluent samples for a Berea sandstone core treated by $13 \mathrm{wt} \%$ acetic acid with $5 \mathrm{wt} \%$ ammonium chloride as a preflush and $3 \mathrm{PV}$ of $13 \mathrm{wt} \%$ acetic acid with $1 \mathrm{wt} \% \mathrm{HF}$ as the main flush at $75^{\circ} \mathrm{F}$ and $5 \mathrm{~cm}^{3} / \mathrm{min}$.

In the core flood experiment on the Bandera sandstone core using acetic-HF acids, $\mathrm{Si}$ concentration reached as high as $1,700 \mathrm{mg} / \mathrm{l}$ during the main flush stage, while Al concentration was close to 0 during the whole experiment (Fig. 44). This is also the same as we saw in the core flood experiment using formic-HF acids (Fig. 14), and was explained earlier. 


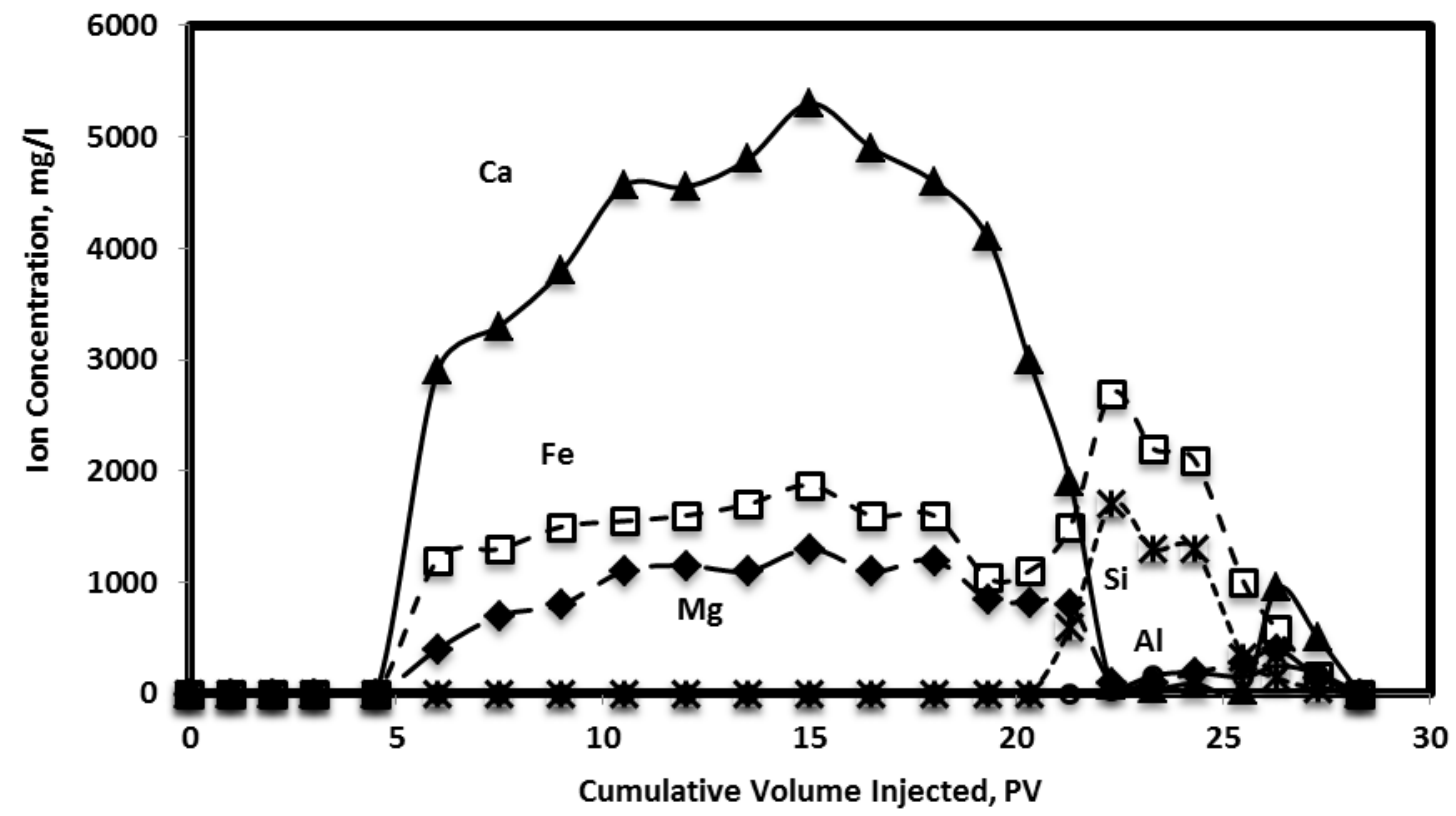

Fig. 44-Analysis of core flood effluent samples for a Bandera sandstone core treated by $13 \mathrm{wt} \%$ acetic acid with $5 \mathrm{wt} \%$ ammonium chloride as a preflush and $3 \mathrm{PV}$ of $13 \mathrm{wt} \%$ acetic acid with $1 \mathrm{wt} \% \mathrm{HF}$ as the main flush at $75^{\circ} \mathrm{F}$ and $5 \mathrm{~cm}^{3} / \mathrm{min}$.

In all, these core flood experiments further confirmed that $13 \mathrm{wt} \%$ acetic-HF acids and 9 wt $\%$ formic-HF acids have almost the same performance in the reactions with clays. And different clays release different metal ions when reacting with acetic-HF or formic-HF acids. 


\section{CONCLUSIONS}

Based on all the experiments including clay solubility tests and core flood experiments, under different conditions, the following conclusions can be drawn from this study:

1. Different clay minerals release very different amounts or types of metal ions when treated with formic/acetic and HF acid mixtures. Kaolinite releases large and equal amount of $\mathrm{Si}$ and $\mathrm{Al}$, while chlorite and illite majorly release $\mathrm{Si}$ and $\mathrm{Fe}$.

2. Sandstone cores with different mineral compositions response very differently to formic-HF acid system, And this observation is consistent with the result from clay solubility tests.

3. For the formic-HF acids, more concentrated $\mathrm{HF}$ can react with more clay minerals, even though the concentration of formic acid is consistent.

4. During preflush stage using formic acid, the alluminosilicates were untouched at all.

5. At room temperature, formic acid is not effective in removing carbonates in a sandstone reservoir. It becomes more effective at higher temperatures.

6. In spite of the acidity difference between formic and acetic acids, under the same condition, 13 wt $\%$ acetic-HF and 9 wt $\%$ formic-HF acids have almost the same performance when reacting with clay minerals.

7. Sandstone cores of which the main clay mineral is illite only release very little amount of $\mathrm{Al}$ during the acid treatment. 
8. After treating these 3 clay minerals with $9 \mathrm{wt} \%$ formic- $6 \mathrm{wt} \% \mathrm{HF}$ or $13 \mathrm{wt} \%$ acetic- $6 \mathrm{wt} \% \mathrm{HF}$ under room temperature for 0.5 hour, no $\mathrm{AlF}_{3}$ precipitate was identified by SEM and EDS. 


\section{REFERENCES}

Abrams, A., Scheuerman, R.F., Templeton, C.C., Richardson, E.A. 1983. Higher-pH Acid Stimulation Systems. SPE Journal of Petroleum Technology 35(12): 21752184.

Al-Harbi, B.G., Al-Khaldi, M.H., and AlDossary, K.A. 2011. Interactions of OrganicHF Systems with Aluminosilicates: Lab Testing and Field Recommendations. Paper SPE 144100 presented at the SPE European Formation Damage Conference, Noordwijk, The Netherlands, 7-10 June.

Blake, R.E. and Walter, L.M. 1999. Kinetics of Feldspar and Quartz Dissolution at 70$80^{\circ} \mathrm{C}$ and Near-neutral pH: Effects of Organic Acids and $\mathrm{NaCl}$. Geochimica et Cosmochimica Acta 63(13-14): 2043-2059.

Buijse, M., Boer, P., Breukel, B., Burgos, G. 2004. Organic Acids in Carbonate Acidizing. SPE Production \& Operations 19(3): 128-134.

Chang, F.F., Nasr-El-Din, H.A., Lindvig, Qui, X.W. 2008. Matrix Acidizing of Carbonate Reservoirs Using Organic Acids and Mixture of $\mathrm{HCl}$ and Organic Acids. Paper SPE 116601 presented at the SPE Annual Technical Conference and Exhibition, Denver, Colorado, USA, 21-24 September.

Chatelain, J.C., Silberberg, I.H., and Schechter, R.S. 1976. Thermodynamic Limitations in Organic-Acid/Carbonate Systems. SPEJ 16(4): 189-195.

Dungan, C.H., Van Wazer, J.R. 1970. Compilation of Reported $\mathrm{F}^{19}$ NMR Chemical Shifts 1951 to Mid-1967. Appendix I. Wiley-Interscience, New York.

Gdanski, R. 1998. Kinetics of Tertiary Reactions of Hydrofluoric Acid on 
Aluminosilicates. SPE Production \& Operations 13(2): 75-80.

Gdanski, R.D. 1999. Kinetics of the Secondary Reaction of HF on Alumino-Silicates. SPE Production \& Operations 14(4): 260-268.

Gdanski, R.D. 2000. Kinetics of the Primary Reaction of HF on Alumino-Silicates. SPE Production \& Operations 15(4): 279-287.

Gdanski, R.D. and Shuchart, C.E. 1996. Newly Discovered Equilibrium Controls HF Stoichiometry. SPE Journal of Petroleum Technology 48(2): 145-149.

Gidley, J.L. 1985. Acidizing Sandstone Formations: A Detailed Examination of Recent Experience. Paper SPE 14164 presented at the SPE Annual Technical Conference and Exhibition, Las Vegas, Nevada, 22-25 September.

Izgec, O.: 2009. Reactive Flow in Vuggy Carbonates: Methods and Models Applied to Matrix Acidizing of Carbonates. PhD dissertation. Texas A\&M U., College Station, Texas.

Mohammad, A., Al-khaldi, M.H., Al-Mutairi, S.H., Al-Zahrani, A.A. 2011. Acidizing Induced Damage in Sandstone Injector Wells: Lab Testing and Case Histories. Paper SPE 144007 presented at the SPE European Formation Damage Conference, Noordwijk, The Netherlands, 7-10 June.

Perrin, D., 1981. Dissociation Constants of Organic Bases in Aqueous Solution. Butterworths, London.

Perry, D.L. 2011. Handbook of Inorganic Compounds. Page 89. CRS Press, Boca Raton., Florida.

Scheuerman, R.F. 1988. A Buffer Regulatd HF Acid for Sandstone Acidizing to 550 
Degrees F. SPE Production Engineering 3(1):15-21.

Shuchart, C.E. and Buster, D.C. 1995. Determination of the Chemistry of HF Acidizing with the Use of ${ }^{19}$ F NMR Spectroscopy. Paper SPE 28975 presented at the SPE International Symposium on Oilfield Chemistry, San Antonio, Texas, 14-17 February.

Shuchart, C.E. and Gdanski, R.D. 1996. Improved Success in Acid Stimulations with a New Organic-HF System. Paper SPE 36907 presented at the European Petroleum Conference, Milan, Italy, 22-24 October.

Simon, D.E. and Anderson, M.S. 1990. Stability of Clay Minerals in Acid. Paper SPE 19422 presented at the SPE Formation Damage Control Symposium, Lafayette, Louisiana, 22-23 February.

Smith, C.F. and Hendrickson, A.R. 1965. Hydrofluoric Acid Stimulation of Sandstone Reservoirs. SPE Journal of Petroleum Technology 17(2): 215-222.

Taylor, K.C., Al-Katheeri, M.I., Nasr-El-Din, H.A. Ahmed, I. 2005. Development and Field Application of a New Measurement Technique for Organic Acid Additives in Stimulation Fluids. SPEJ 10(2): 152-160.

Thomas, R.L., Nasr-El-Din, H.A., Mehta, S. Hilab, V., Lynn, J.D. 2002. The Impact of $\mathrm{HCl}$ to HF Ratio on Hydrated Silica Formation During the Acidizing of a High Temperature Sandstone Gas Reservoir in Saudi Arabia. Paper SPE 77370 presented at the SPE Annual Technical Conference and Exhibition, San Antonio, Texas, September 29- October 2. 


\title{
VITA
}

\author{
Name: $\quad$ Fei Yang \\ Address: $\quad$ Richardson Building Room 1011, \\ TAMU \\ College Station, TX 77840 \\ Email Address: fei.yang@pe.tamu.edu \\ Education: $\quad$ B.S., Pharmaceutical Science and Technology, \\ Tianjin University, 2008 \\ M.S., Petroleum Engineering, Texas A\&M \\ University, 2012
}

